\title{
Effect of radiation on hepatic fat metabolism in rat and mouse: A role of radiation-induced TNF- $\alpha$ in the regulation of FAT/CD36
}

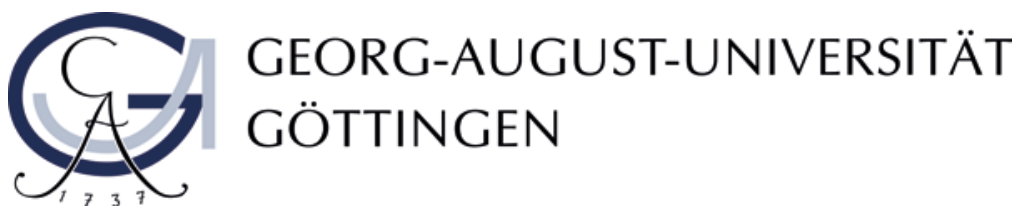

\author{
Dissertation \\ zur Erlangung des Doktorgrades \\ der Mathematisch-Naturwissenschaftlichen Fakultäten \\ der Georg-August-Universität zu Göttingen
}

vorgelegt von

Gesa Martius

aus Lüneburg

Göttingen 2015 
D7

Referent: Prof. Dr. med. Dr. h. c. Wolfgang Engel

Korreferent: PD Dr. rer. nat. Wilfried Kramer

Tag der mündlichen Prüfung: 27.07.2015 


\section{Contents}

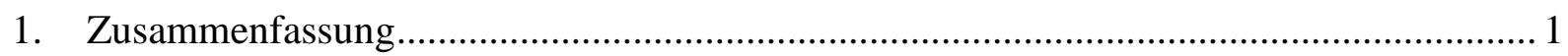

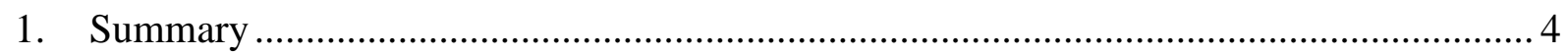

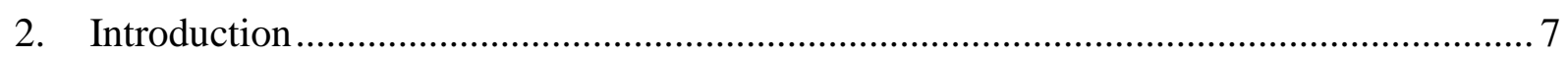

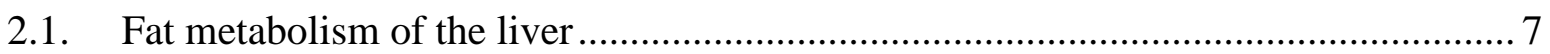

2.1.1. Fat metabolism in healthy liver ............................................................... 7

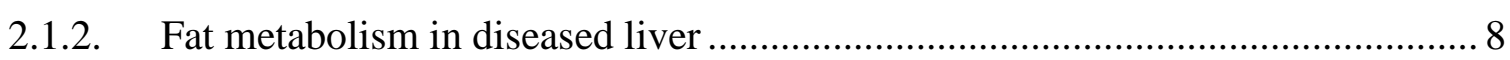

2.2. The role of FAT/CD36 in fat metabolism .......................................................... 9

2.3. Hepatic radiotherapy and metabolic disorder ......................................................... 11

2.4. Animal model for studies of liver irradiation ......................................................... 12

2.5. Aims of the Study …....................................................................................... 13

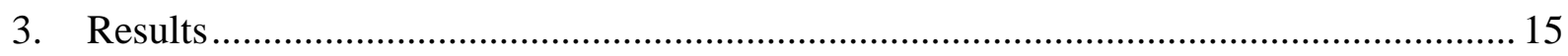

3.1 Hepatic fat accumulation and regulation of FAT/CD36: an effect of hepatic

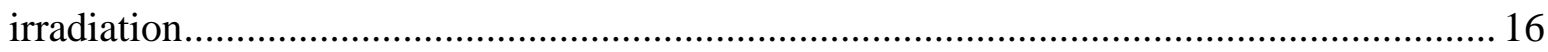

3.2. The anti-TNF- $\alpha$ antibody infliximab inhibits the expression of fat-transporter-protein FAT/CD36 in a selective hepatic-radiation mouse model.................................................... 32

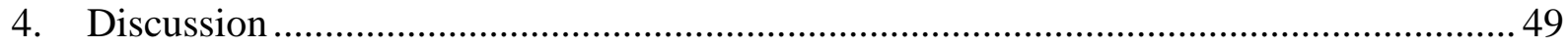

4.1. Hepatic fat accumulation and regulation of FAT/CD36: an effect of hepatic

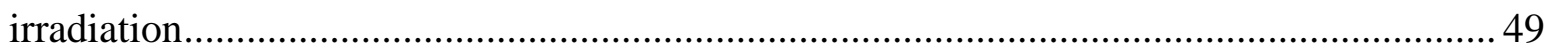

4.1.1. Hepatic inflammation and fat metabolism ....................................................... 51

4.1.2. Fat accumulation and regulation of FAT/CD36 in rat liver after irradiation ..... 51 4.2. The anti-TNF- $\alpha$ antibody infliximab inhibits the expression of fat-transporter-protein FAT/CD36 in a selective hepatic-radiation mouse model.................................................... 54

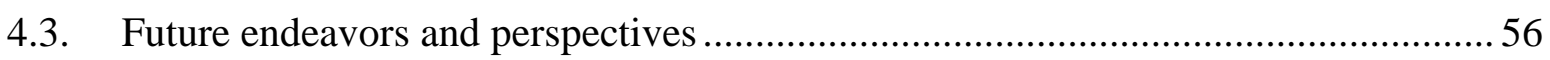

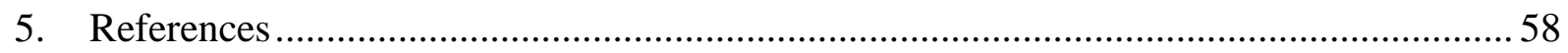

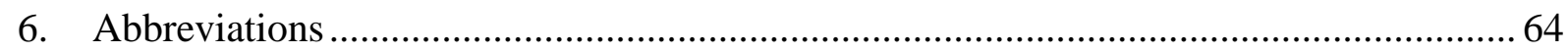

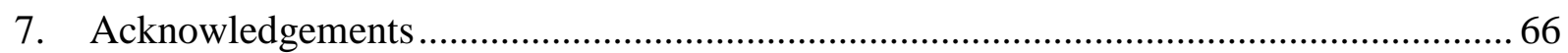

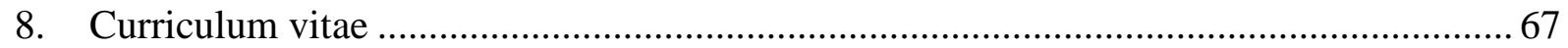

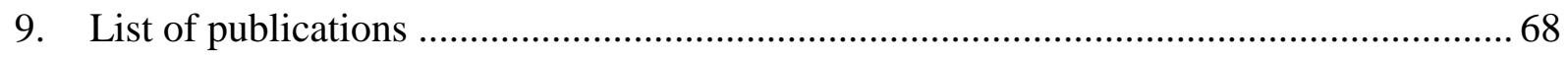




\section{List of figures}

Figure 1. Pathways of fatty acids in the liver. Liver Free Fatty Acids (FFA) are derived from uptake of circulating FFAs and de novo synthesis. The FFAs are either oxidized ( $\beta$ oxidation) or esterified to triglycerides. Triglycerides are then released into circulation as Very Low Density Lipoprotein (VLDL) or stored within hepatocytes in vacuoles. (Guturu and Duchini 2012) (Int J Hepatol. 2012; 2012: 212865. Published online 2012 Jun 25. doi: 10.1155/2012/212865).

Figure 2. Scheme of Non-Alcoholic Fatty Liver Disease (NAFLD) spectrum from steatosis (fatty liver) to Non-Alcoholic SteatoHepatitis (NASH) (http://www.fix.com/blog/sugar-from-head-to-toe/) (05.06.2015).

Figure 3. Scheme of the function of FAT/CD36 in the liver; TG = Triglycerides, FFA = Free Fatty Acids, FAT/CD36 = Fatty Acid Translocase/cluster of differentiation 36 (modified from http://www.surgery.usc.edu/hepatobiliary/liversurgery.html).

Figure 4. Scheme of selective whole liver irradiation of the rat. (A) by computer tomography (CT) calculated radiation field and dose distribution of rat liver irradiation, (B) example of rat liver irradiation protocol with an anaesthetized rat and a clinical linear accelerator. (Sultan et al. 2013) (Liver Int. 2013 Mar;33(3):459-68. doi: 10.1111/liv.12073. Epub 2013 Jan 18, page 3).

Figure 5: Infiltration of Neutrophil Granulocytes by using antibody against CD11b/c (marker for Neutrophil Granulocytes and macrophages) after irradiation. A) shamirradiated (control) B) $6 \mathrm{~h}$ after irradiation (unpublished pictures of our group). 


\section{Zusammenfassung}

Die Strahlentherapie ist eine wichtige Methode, um Tumore zu behandeln. Die entscheidenden Effekte der Bestrahlung von tumorösem Gewebe werden der Schädigung von Tumor-DNA und der Zerstörung von Tumorgefäßen zugeschrieben. Strahlentherapie alleine oder in Kombination mit zytotoxischen Wirkstoffen ist eine wesentliche Methode in der Krebstherapie. Mit dem Aufkommen von atmungsgesteuerter Strahlentherapie und der Verbesserung stereotaktischer Techniken ist die strahlentherapeutische Behandlung von Lebertumoren möglich geworden. Dagegen ist jedoch die Auswirkung von Strahlung auf normales Gewebe, einschließlich das der Leber, wenig bekannt.

Die Leber ist verantwortlich für den Energiestoffwechsel und die Entgiftung. Die Leberläppchen repräsentieren einen Schwamm aus Gefäßen und Schnüren aus Hepatozyten mit angrenzenden Kupffer-Zellen und einem variierenden Sauerstoffdruck, der mit einer Anfälligkeit für Mechanismen von oxidativem Stress assoziiert ist. Die Leber ist dadurch empfindlich gegenüber Bestrahlung, welche zusammen mit anderen Noxen im Verlauf der Zeit zur Leberschädigung (z.B. Entwicklung von Fibrose/Zirrhose) führen kann. Deshalb kann Bestrahlung zur Schädigung von nicht-tumorösem Gewebe führen. Strahleninduzierte Lebererkrankung (Radiation-Induced Liver Disease = RILD) ist eine klinische Komplikation, die durch das Auftreten von Aszites und Anzeichen einer verminderten Leberfunktion gekennzeichnet ist. Die Histopathologie zeigt Venenverschlusskrankheit und Atrophie von umliegenden Hepatozyten.

Bestrahlung induziert bekanntermaßen eine Immunantwort und beeinflusst Fettstoffwechselwege, wobei Zytokine wie Tumornekrosefaktor- $\alpha$ (TNF- $\alpha$ ) eine Schlüsselrolle spielen. Obwohl eine Verbindung zwischen Leberentzündung und Fettakkumulation bekannt ist, sind die metabolischen Veränderungen nach Bestrahlung wenig untersucht.

Das Ziel der Arbeit war, die Änderungen in der Fettaufnahme und des Lipidprofils nach strahleninduzierter Leberschädigung zu untersuchen. Desweiteren wurden die Gene, die für Proteine kodieren, die am Import von Fett in die Leber nach Bestrahlung beteiligt waren, untersucht,.

Rattenlebern wurden selektiv in vivo bestrahlt (25 Gray (Gy)), scheinbestrahlte Ratten fungierten als Kontrollen. Zusätzlich zum Rattenmodel, welches bereits in unserem Labor etabliert war, wurde ein Mausmodel der selektiven Einzeldosisbestrahlung (25 Gy) bei 
gleichzeitiger Verabreichung von jeweils TNF- $\alpha$ und anti-TNF- $\alpha$, Infliximab (IFX), entwickelt.

Mit Hilfe von Nile Red- und Sudan III-färbung wurde die Fettakkumulation im Lebergewebe betrachtet. Leberlipide wurden durch colorimetrische Assays in Lebergewebe und Serum untersucht, Proteinlevel und mRNA-Expression wurden mittels Immunhistologie, Western Blot und RT-PCR im Lebergewebe analysiert. Veränderungen von FAT/CD36 auf Proteinebene nach Bestrahlung wurden in vitro in einer humanen Monozytenzelllinie (U937) mit oder ohne Gabe von anti-TNF- $\alpha$ untersucht.

In der Rattenleber konnte mittels Nile Red in Gefrierschnitten eine rasche Zunahme (1248 hours (h)) von Fetttröpfchen dargestellt werden. Entsprechend waren die Konzentrationen der hepatischen Triglyzeride (TG) und der freien Fettsäuren (FFA) erhöht. Nach Bestrahlung wurde ein frühzeitiger Anstieg (3-6 h) der Serumwerte von High Density Lipoprotein-Cholesterin (HDL-C), sowie die TG- und CholesterinVeränderungen mit darauffolgender Abnahme in der Rattenleber gemessen.

Zusätzlich war die mRNA-Expression des Gens welches das Fetttransporterproteins FAT/CD36 kodiert erhöht, durch Immunhistologie wurde eine basolaterale und zytoplasmatische Lokalisierung dieses Transporters in Hepatozyten gezeigt. Desweiteren waren Apolipoproteine B100 und C3 und Schlüsselenzyme des Fettstoffwechsel wie Acetyl-CoA Carboxylase, Lipoproteinlipase, Carnitin-Palmitoyltransferase und MalonylCoA Decarboxylase nach 12-24 h induziert. Eine frühe Aktivierung des NFkBSignalweges $(\mathrm{I} \kappa \mathrm{B} \alpha)$ durch TNF- $\alpha$ konnte beobachtet werden, gefolgt von einer signifikanten Erhöhung der Serummarker für Leberschädigungen (Aspartat-Transaminase (AST) und Glutamatdehydrogenase (GLDH)) nach einmaliger Bestrahlung von Rattenlebern. Die Blockierung von TNF- $\alpha$ durch anti-TNF- $\alpha$ in Zellkultur (U937) verhinderte die gesteigerte strahleninduzierte Bildung von FAT/CD36.

Ähnlich wie in der Rattenleber beobachtet, war die Genexpression von TNF- $\alpha$, einem proinflammatorischen Protein, in Mauslebergewebe im Vergleich zu scheinbestrahlten Kontrollen früh (1-3 h) induziert. Die gesteigerte TNF- $\alpha$-Expression wurde zeitlich gefolgt von erhöhten Konzentrationen der Leber-Triglyzeride (6-12 h). Demgegenüber wurde ein verringertes Niveau der TG im Serum von bestrahlten Tieren zu den Zeitpunkten nachgewiesen, zu denen die Leber-Triglyzeride erhöht waren.

Übereinstimmend mit der Höhe der TG-Konzentration in Mauslebern zeigte die Sudanfärbung von Leberkryoschnitten eine rasche (3-6 h) Akkumulation von Fett und die Zunahme in der Größe der Fetttröpfchen nach Bestrahlung. Parallel dazu war FAT/CD36 
auf Proteinebene nach Bestrahlung erhöht. In vivo verhinderte die Blockierung von TNF- $\alpha$ durch anti-TNF- $\alpha$ die Zunahme von FAT/CD36 in der Mausleber.

In der Immunhistochemie wurde die basolaterale und zytoplasmatische Lokalisierung von FAT/CD36 in murinen Hepatozyten gezeigt. Desweiteren konnte FAT/CD36 in CK19+positiven Zellen (Gallengangzellen), SMA+-positiven Zellen (Myofibroblasten) und F4/80+- positiven Zellen (Makrophagen) der Mausleber nachgewiesen werden.

Die Ergebnisse der in vivo- und in vitro-Daten weisen darauf hin, dass IFX dadurch, dass es lösliches TNF- $\alpha$ blockiert, FAT/CD36 auf Proteinebene inhibiert, die Zunahme von FAT/CD36 durch TNF- $\alpha$ oder/und Bestrahlung in Leberexperimenten demnach verhindert; eine Voraussetzung dafür den Fetttransportes ins Gewebe zu kontrollieren.

Der beobachtete Effekt von anti-TNF- $\alpha$ könnte zu einer Verminderung entzündlicher Prozesse, ausgelöst durch Bestrahlung und/oder TNF- $\alpha$, in der Leber beitragen. Außerdem deutet das Vorhandensein von FAT/CD36 in verschiedenen Leberzelltypen, abgesehen von Hepatozyten, auf eine aktive Teilnahme dieser Zellen an den Mechanismen der Fettaufnahme in der Leber hin. 


\section{Summary}

Radiotherapy is an important method to treat tumors. The positive effects of irradiation on tumoral tissue are thought to be due to the damage of the DNA of tumor cells and the damage of tumor vessels. Radiation as single or together with anti-tumor drugs is a main therapy against cancer. Recent development in the radiotherapy such as respiratory-gated radiotherapy and the amelioration of stereotactic techniques has made radiotherapy of liver tumors possible. However, there has been little knowledge how irradiation affects healthy tissue. Accordingly, the effect of irradiation on healthy liver tissue is still poorly understood.

The liver is responsible for energy metabolism and detoxification. Its lobules represent a sponge of vessels and hepatocyte cords with adjacent Kupffer cells and with a varying oxygen tension, implicating sensitivity to oxidative stress mechanisms. The liver is thus considered to be sensitive to irradiation, which together with other noxae could lead to liver damage (e.g. development of fibrosis/cirrhosis) over the course of time. Hence, irradiation might cause damage of (non-tumoral) liver tissue. Radiation-Iinduced Liver Disease (RILD) is a clinical complication characterized by the appearance of ascites and signs of decreased liver function. Histopathology shows veno-occlusive disease and atrophy of adjacent hepatocytes.

Irradiation is known to induce an inflammatory response and affects fat metabolic pathways where cytokines, especially Tumor Necrosis Factor- $\alpha$ (TNF- $\alpha$ ), play a key role. Although, a link between hepatic inflammation and fat accumulation has been described, the metabolic changes after irradiation have been poorly studied.

The aim of the current study was to investigate changes in fat uptake and lipid profile after radiation-induced liver damage. Furthermore, the genes encoding proteins which are involved in transport of fat into the liver after selective liver irradiation were analyzed.

Rat livers were selectively irradiated in vivo (25 Gy), sham-irradiated rats served as controls. In addition to the rat model, already established in our laboratory, a mouse model of selective single-dose irradiation (25 Gy) in presence or absence of TNF- $\alpha$ and antiTNF- $\alpha$ antibody, infliximab (IFX), was established.

Nile red and Sudan staining were used to observe the fat accumulation in liver tissue. Hepatic lipids were studied by colorimetric assays in liver tissue and serum. Protein level and mRNA expressions were studied by immunohistology, Western Blot analysis and RTPCR in liver tissue, respectively. Changes in FAT/CD36 protein level were studied in 
vitro in a human monocyte cell line U937 after irradiation in presence or absence of antiTNF- $\alpha$ antibody.

In rat liver, Nile-Red staining of cryosections showed a quick (12-48 hours (h)) increase of fat droplets. Accordingly, concentrations of hepatic triglycerides (TG) and free fatty acids (FFA) were elevated. An early increase (3-6 h) in the serum level of High Density Lipoprotein-Cholesterol (HDL-C), TG and cholesterol was measured after single-dose irradiation in rat liver followed by a decrease thereafter.

In addition, an increased mRNA expression of the fat transporter protein FAT/CD36 was detected, immunohistochemistry revealed basolateral and cytoplasmic localization of this transporter in hepatocytes. Moreover, apolipoprotein-B100, -C3 and key enzymes of fat metabolism (acetyl-CoA carboxylase, lipoprotein lipase, carnitine palmitoyltransferase, malonyl-CoA decarboxylase) involved in fat metabolism were induced at 12-24 h. An early activation of the NFאB pathway $(\operatorname{I\kappa B} \alpha)$ by TNF- $\alpha$ was seen, followed by a significant elevation of serum markers for liver damage (AST and GLDH) after singledose irradiation in rat liver. TNF- $\alpha$ blockage by anti-TNF- $\alpha$ in cell culture (U937) prevented the increase of FAT/CD36 protein level caused by irradiation.

Similar to what was observed in rat liver, an early (1-3 h) induction of TNF- $\alpha$ gene expression, a pro-inflammatory protein, was seen in mouse liver tissue compared to shamirradiated controls. Increased TNF- $\alpha$ expression was followed by elevated hepatic TG concentration (6-12 h). In contrast, a decreased TG level was detected in the serum of irradiated animals at the same time points when liver TG were elevated.

Corresponding to TG levels in mouse liver, Sudan staining of liver cryosections showed a quick (3-6 h) accumulation and increase in size of fat droplets after irradiation. In parallel, the fat transporter FAT/CD36 was increased at protein level after irradiation. In vivo, TNF- $\alpha$ blockage by anti-TNF- $\alpha$ in mice liver prevented the increase of FAT/CD36.

Immunohistochemistry showed the basolateral and cytoplasmic localization in mice hepatocytes. Moreover, co-localization of FAT/CD36 was detected in CK-19+- (billary cells), SMA+- (myofibroblast) and F4/80+- (macrophages) cells in mouse liver.

The results (in vivo and in vitro) suggest that IFX, by blocking soluble TNF- $\alpha$, inhibits FAT/CD36 on protein level, preventing the increase of FAT/CD36 caused by TNF- $\alpha$ or/and irradiation in liver experiments, a prerequisite to control fat transport into tissue.

The observed effect of anti-TNF- $\alpha$ might contribute to a reduction of inflammatory processes caused by irradiation and/or TNF- $\alpha$ in liver. Moreover, the presence of 
FAT/CD36 in different liver cell types apart from hepatocytes strongly suggests their active involvement in liver fat uptake mechanisms. 


\section{Introduction}

\subsection{Fat metabolism of the liver}

\subsubsection{Fat metabolism in healthy liver}

The main function of the liver is to maintain the energy homeostasis in the body as it processes and enables the distribution of fatty acids (Reddy and Rao 2006). Despite from synthesizing fatty acids (de novo lipogenesis, DNL), liver has also the capability to degrade and convert the fatty acids approaching from the circulating system (Tamura and Shimomura 2005). The fatty acids may either be oxidized in the mitochondria, stored in the liver or exported to adipose tissue and muscles (Fig. 1) (Frayn et al. 2006).

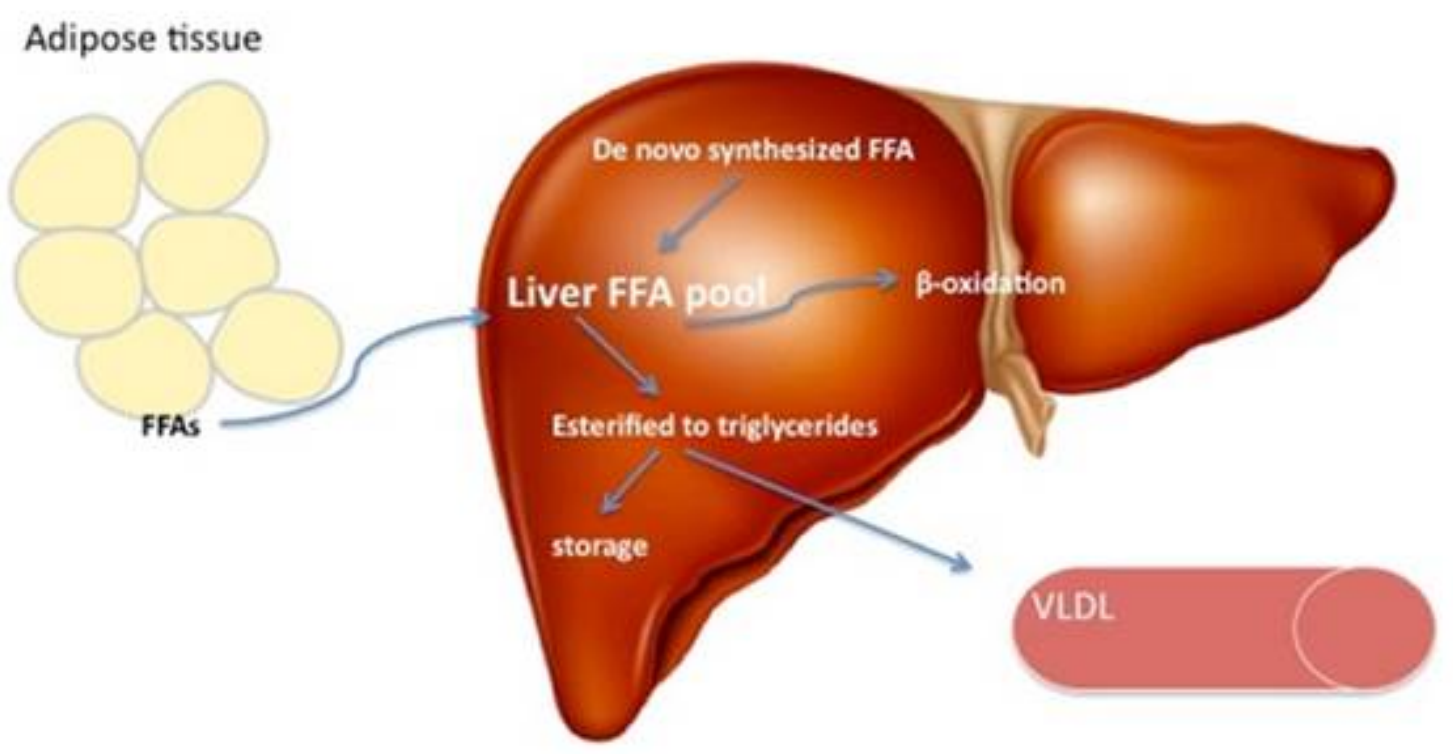

Figure 1. Pathways of fatty acids in the liver. Liver Free Fatty Acids (FFA) are derived from uptake of circulating FFAs and de novo synthesis. The FFAs are either oxidized ( $\beta$-oxidation) or esterified to triglycerides. Triglycerides are then released into circulation as Very Low Density Lipoprotein (VLDL) or stored within hepatocytes in vacuoles. (Guturu and Duchini 2012) (Int J Hepatol. 2012; 2012: 212865. Published online 2012 Jun 25. doi: 10.1155/2012/212865).

The parenchymal cells of the liver, i.e. hepatocytes, are the main responsible cells for metabolizing fat (Hayhurst et al. 2001). In case of high energy demand in the body, the 
intrahepatic fatty acids may be metabolized by $\beta$-oxidation to provide energy in form of Adenosine Triphosphate (ATP) (Nguyen et al. 2008). In the case of low energy demand or increased supply of fatty acids due to dietary conditions, fatty acids are esterified with glycerol to form triglycerides. They can be stored within hepatocytes or exported into the circulating system (Meng et al. 2013). Triglycerides are collected into Very Low-Density Lipoproteins (VLDL) in association with lipoproteins, lipids and phospholipids to be exported from the liver into the peripheral system (Gibbons et al. 2004). Moreover, excessive fatty acids are stored within hepatocytes after being converted to triglycerides to neutralize the lipotoxic consequences (Gibbons et al. 2000).

\subsubsection{Fat metabolism in diseased liver}

Non-Alcoholic Fatty Liver Disease (NAFLD) is identified by an excessive accumulation of intrahepatic triglycerides which is often linked to risk factors such as obesity, type 2 diabetes, metabolic syndrome and coronary heart disease (Fabbrini et al. 2010). Clinically, it could lead to steatosis, Non-Alcoholic SteatoHepatitis (NASH), liver fibrosis, cirrhosis and eventually to hepatocellular carcinoma (Fig. 2) (Adams et al. 2005).

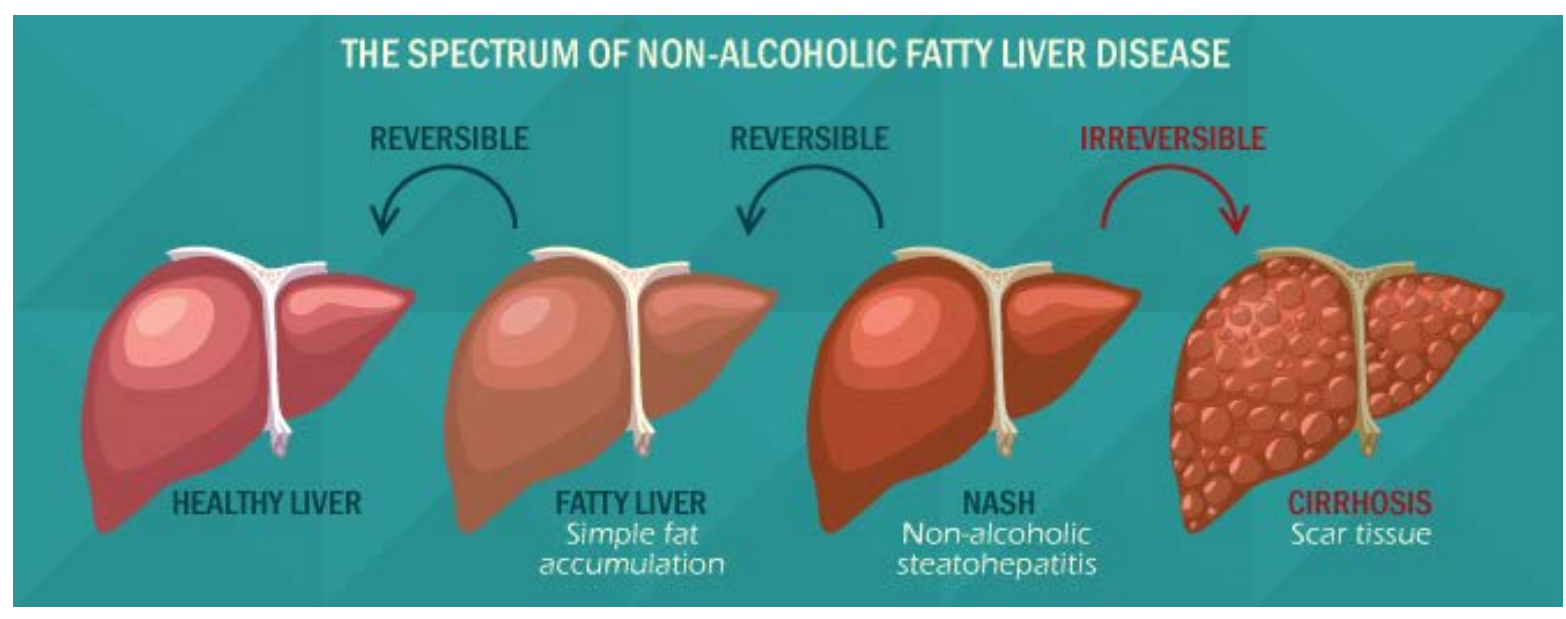

Figure 2. Scheme of Non-Alcoholic Fatty Liver Disease (NAFLD) spectrum from steatosis (fatty liver) to Non-Alcoholic SteatoHepatitis (NASH) (http://www.fix.com/blog/sugar-from-head-to-toe/) (05.06.2015).

The risk for patients to develop NASH and fibrosis increases from $2.7 \%$ in lean individuals to $18.5 \%$ in obese subjects (Adams et al. 2005), although the natural history 
and rate of progression of NAFLD to NASH is contentious (Ekstedt et al. 2006). Patients suffering from diabetes mellitus and patients with an excessive consumption of alcohol, drugs and supernutrition (Cave et al. 2007) are often associated with fatty liver (Marchesini et al. 2001). Steatosis is pathologically characterized by excessive storage of intrahepatic triglycerides in more than 5\% of hepatocytes (Hubscher 2006). Diseases such as hepatitis C, as well as medication and alcohol misuse are reported risk factors to develop steatosis. Indeed, inflammation alone or together with fibrosis worsen the clinical prognosis in the patients who develop NASH (Dixon et al. 2001). In fact, simple steatosis appears to have a low rate of progression to NASH. Subsequently it is believed that the majority of steatosis cases developing NASH with fibrosis or liver injury is due to a constant activation of inflammatory state in human body (Ong and Younossi 2007). A recent study on NAFLD has shown that the progression of steatosis is positively correlated with the grade of lobular inflammation, fibrosis and NASH (Chalasani et al. 2008).The reason why some patients with fatty liver disease develop NASH and others do not, is still unclear. Besides of increased intake of nutritional fat and de novo hepatic lipogenesis, a consequence of hepatic lipid accumulation could be an increased lipolysis from adipose tissue. Additionally, an impaired oxidation of free fatty acids and secretion of VLDL-triglycerides could also be determining factors for this event (Tilg and Moschen et al. 2010). The main source of fatty acids leading to hepatic lipid accumulation and to NAFLD is their supply of serum Non-Esterified Fatty Acids (NEFAs) to the liver. This alone contributes to $60 \%$ of hepatic fat accumulation (Donnelly et al. 2005).

\subsection{The role of FAT/CD36 in fat metabolism}

Fat metabolism is a multifaceted process, which includes the participation and interaction of a huge variety of proteins. Fatty acid oxidative enzymes, e.g. Malonyl-CoA Decarboxylase (MCOAD), Carnitine PalmitoylTransferase (CPT) and lipoprotein lipase (LPL), and fatty acid synthesis enzymes, e.g. Acetyl-CoA Carboxylase (ACC), are holding key positions in fat metabolism pathways (Schreurs et al. 2010). In addition to these enzymes, membrane proteins such as Apolipoproteins (ApoC3 and ApoB100) and mitochondrial mitofusin-2 (Mtf-2) (Jong et al. 2001;Sebastian et al. 2012) along with fat transporter proteins (Fatty Acid Binding Proteins (FABPs), Fatty Acid Transport Proteins (FATPs) and Fatty Acid Translocase (FAT/CD36)) contribute to distribution of fatty acids inside the cell and the peripheral system (Glatz et al. 2010). The recently discovered 
cluster of differentiation protein 36 (FAT/CD36) is known to be a vital player in liver fatty acid transport (Fig. 3).

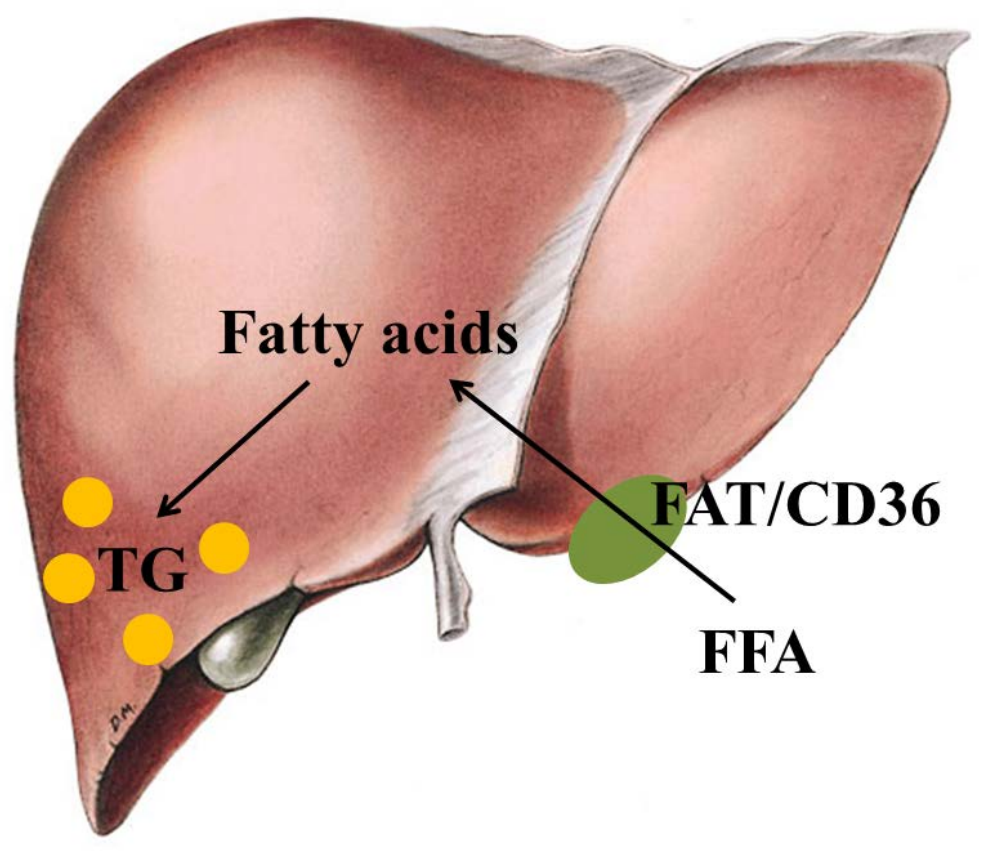

Figure 3. Scheme of the function of FAT/CD36 in the liver; TG = Triglycerides, FFA = Free Fatty Acids, FAT/CD36 = Fatty Acid Translocase/cluster of differentiation 36 (adopted and modified from http://www.surgery.usc.edu/hepatobiliary/liversurgery.html).

In different experimental models of NAFLD an elevated FAT/CD36 level was shown (Ge et al. 2010; Larter et al. 2010). Fatty Acid Translocase (FAT/CD36) is a transmembrane transport protein which is localized at the cell membrane of different cells, including macrophages, adipocytes and hepatocytes and is present in different organs (Zhang et al. 2003). Posttranslational modifications are known for FAT/CD36, mainly N-linkedglycosylation (Lauzier et al., 2011). It plays a critical role in metabolic disorders like diabetes mellitus, obesity and non-alcoholic hepatic steatosis (Fabbrini et al. 2010;Fernandez-Real et al. 2009; Glatz et al. 2010;Su and Abumrad 2009) where the level of FAT/CD36 is increased and probably contributes to development of fatty liver disease (He et al., 2011). In contrast, some research groups suggest that the protein is not produced significantly in rodent liver (Abumrad et al. 1993). Presently, the occurrence and the level of FAT/CD36 is supposed to be dependent on gender, genetic background, and is 
reflective of its numerous functions (Fabbrini et al. 2010). Active FAT/CD36 is an $88 \mathrm{kDa}$ protein containing two domains crossing the cell membrane (Su and Abumrad 2009). It has a variety of ligands including fatty acids (Glatz et al. 2010). It has been shown that the inactive form of FAT/CD36 is a non-glycosylated protein of $54 \mathrm{kDa}$ (Glatz et al. 2010), that has ten putative glycosylation sites which can be glycosylated in the Golgi apparatus and in the endoplasmic reticulum (Hoosdally et al. 2009). The pattern of FAT/CD36 changes under different metabolic disorders; mostly elevated FAT/CD36 protein is leading to a higher import of fatty acids into the cells. For instance in diabetic patients, it is significantly participating in liver steatosis and oxygen stress induced by lipids (Bonen et al. 2006).

\subsection{Hepatic radiotherapy and metabolic disorder}

In recent years, ionizing radiation has emerged as a useful tool for the treatment of tumors alongside surgery, chemotherapy, immunotherapy and hormonal therapy. Ionizing radiation causes damage of the tumor- and normal cells by damaging their DNA. However, normal cells can usually repair the damage, recover and maintain their normal functions. In general, the ability of tumor cells to repair the damages is not as effective as of normal cells. This concept is used for cancer treatment (Baskar et al. 2012). Although with the advancement of radiotherapy, efforts have been made to avoid or minimize the damage to healthy tissue, the treatment of liver cancer with ionizing radiation is still problematic, as the diseased liver is a highly sensitive organ and has low tolerance to radiotherapy (Cheng et al. 2002). There are also conflicting reports of simultaneously applied radiotherapy and chemotherapy (concomitant chemoradiotherapy). In addition, pretreatment of the liver with chemotherapeutics is known to lower the tolerance dose of ionizing radiation (Ruhl et al. 2010) which is another challenge in this regard.

As the liver is the most important metabolizing organ in the body, simultaneous exposure to radiation energy and administration of cytostatic agents could lead to hepatic metabolic dysfunction, which might be connected to radiation-induced protein degradation and cell stress response in membranes. Recently, a radiation-induced increased peroxidation together with cell membrane damage and related proteins has been shown in fibroblasts (Kwon et al. 2014). In fact, mechanisms of fatty acid transport have been poorly investigated in other organs and furthermore the consequences of targeted liver radiation on fatty acid transport have not been studied so far. 


\subsection{Animal model for studies of liver irradiation}

Irradiation is one of the therapeutic tools against cancer. Administration of irradiation however has negative effects on non-tumoral tissue (Burdak-Rothkamm and Prise 2009). The liver is affected by the development of primary tumors such as hepatocellular or cholangiocellular carcinoma, but most often the liver is the target of tumor metastasis (Koshariya et al. 2007). It is considered to be sensitive to irradiation (Christiansen et al. 2006;Christiansen et al. 2007) with a threshold radiation dose of 20-30 Gy (Gray) for the whole liver (Anscher et al. 1990).
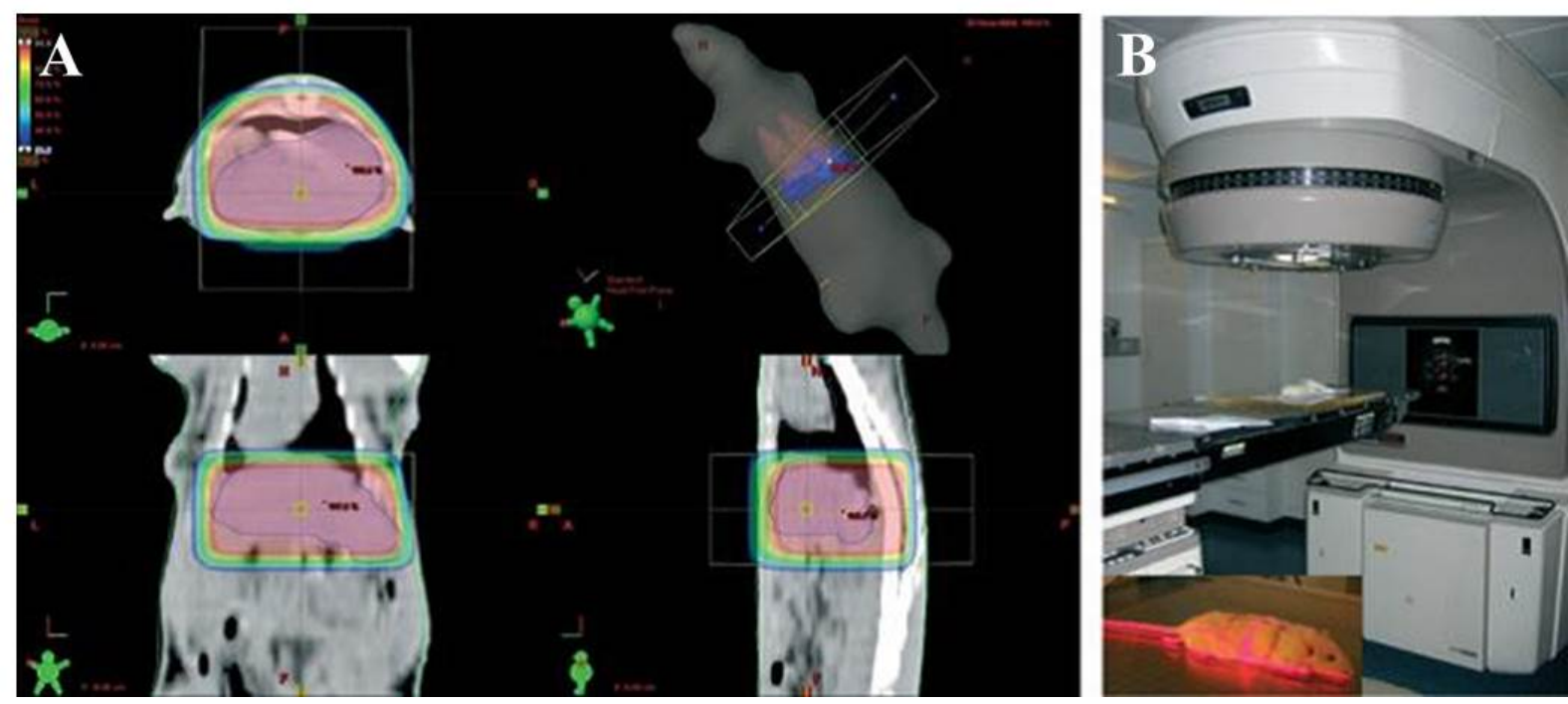

Figure 4. Scheme of selective whole liver irradiation of the rat. (A) by computer tomography (CT) calculated radiation field and dose distribution of rat liver irradiation, (B) example of rat liver irradiation protocol with an anaesthetized rat and a clinical linear accelerator. (Sultan et al. 2013) (Liver Int. 2013 Mar;33(3):459-68. doi: 10.1111/liv.12073. Epub 2013 Jan 18, page 3).

Because the molecular changes in normal irradiated liver have not been analysed so far, a model for rat liver irradiation was developed by Christiansen et al. (Fig. 4) (Christiansen et al. 2006). Its purpose was to examine and understand acute and chronic effects of selective single-dose irradiation at mRNA and protein level in the liver. In addition to this rat model of single-dose liver irradiation, a mouse model for selective single-dose irradiation of the liver was established. 


\subsection{Aims of the Study}

The liver is the central organ for the control of the glucose, protein and fat metabolism. Therefore, hepatic functional impairment can lead to serious consequences regarding metabolic diseases such as hepatic steatosis. The main reasons for this disorder are the disturbance or imbalance in fatty acid uptake, synthesis, oxidation and secretion. Radiation-induced metabolic disruption has been reported which resulted in accumulation of fat in adipose tissue (Jo et al. 2011). Clinically, Radiation-Induced Liver Disease (RILD) is a well-known problem (Shim et al. 2007) mainly due to vessel damage (Lawrence et al. 1995), which leads to an increase of acute phase proteins with release of inflammatory mediators (Malik et al. 2010;Sultan et al. 2012). Although an association between excessive fat accumulation followed by inflammation has been described, little is known about the effect of single-dose selective liver irradiation on hepatic fat accumulation and associated fat transport pathways.

A previous study of our group showed radiation-induced inflammation which was mediated by inflammatory cytokines (esp. TNF- $\alpha$ ) (Christiansen et al. 2007) and chemokines followed by infiltration of neutrophil granulocytes in the irradiated liver (Malik et al. 2010). The aim of the present work was to explore the alteration in lipid profile and fat uptake in relation to radiation-induced hepatic inflammation. Furthermore, we were interested to examine the protein(s) involved in transport of fat into the liver after selective liver irradiation.

The general question was: Is fat uptake and fat metabolism affected by irradiation and/or radiation-induced inflammation (role of TNF- $\alpha$ ) in the liver? 


\section{Therefore the experiments addressed the following targets:}

- To investigate if fat accumulation can be seen in irradiated liver through staining and lipid profiles analysis in serum and liver after single-dose irradiation

- To determine the main cell type of fat transporter FAT/CD36 production in the liver and to examine its regulation after irradiation

- To examine the relation between fat metabolism and radiation-induced inflammation in vivo and in vitro:

a) Investigation of the direct or indirect (through TNF- $\alpha$ ) effect of irradiation on fat transporter FAT/CD36 gene expression and protein level and

b) Whether inhibition of TNF- $\alpha$ by anti-TNF- $\alpha$-therapy (infliximab) could reverse the effect of radiation on FAT/CD36

The understanding of this metabolic pathway can lead to new potential therapeutic targets for treatment of steato-hepatitis in patients during or after upper abdominal radiation treatment. 


\section{Results}

The main focus of this study was to investigate the influence of ionizing single-dose irradiation and/or radiation-induced inflammation on the lipid profile and proteins involved in fat metabolism. To achieve this aim, different molecular and biochemical techniques were used in several animal and cell models. In addition to analyzing the changes in lipid profile of these studied models, expression of genes encoding for proteins that are involved in fat metabolism were investigated at mRNA and protein level. The main focus was put onto fatty acid transporter FAT/CD36, a key protein in fatty acid transport. The results of these studies were set into two of the following manuscripts, which have already been published in peer-reviewed journals.

3.1. Hepatic fat accumulation and regulation of FAT/CD36: an effect of hepatic irradiation

3.2. The anti-TNF- $\alpha$ antibody infliximab inhibits the expression of fattransporter-protein FAT/CD36 in a selective hepatic-radiation mouse model 


\subsection{Hepatic fat accumulation and regulation of FAT/CD36: an effect of hepatic irradiation}

In the first part of the thesis the fat metabolism was analyzed in rat liver following single-dose irradiation. Increasing intracellular fat accumulation was observed via fluorescent staining with lipophilic dye Nile Red. The analysis of the lipid types revealed increased free fatty acid levels, triglycerides and total lipids in the liver at the corresponding time points (12, 24 and $48 \mathrm{~h}$ after irradiation). Strikingly, the triglycerides were decreased at the corresponding time points in the serum. mRNA levels of several genes encoding proteins that are involved in fat metabolism of hepatocytes were analyzed by real time PCR, whereas fatty acid transporter FAT/CD36 was chosen for further studies; it showed the most outstanding gene expression among all studied genes. FAT/CD36 plays a crucial role in metabolic disorders and diabetes in regulating fatty acid transport and fat accumulation in the liver of those patients. Parallel to increase in fat droplets, increasing protein level of FAT/CD36 in total rat liver lysate of both active and inactive isoform could be shown. Moreover, TNF- $\alpha$, a pro-inflammatory cytokine, has shown to be the main inducer of FAT/CD36 through the NF- $\kappa$ B pathway in our model. In vitro data revealed an inhibition of the FAT/CD36 protein increase caused by irradiation by using anti-TNF- $\alpha$ antibody to block the radiation-induced TNF- $\alpha$ protein increase.

Authors: Gesa Martius, Salamah Mohammad Alwahsh, Margret Rave-Fränk, Clemens Friedrich Hess, Hans Christiansen, Giuliano Ramadori and Ihtzaz Ahmed Malik

Status: Published in Int J Clin Exp Pathol. 2014 Jul 15;7(8):5379-92. eCollection 2014

Impact Factor: 1.783

\section{Author contribution to the work:}

1. Gesa Martius: performed the main experiments, analyzed the data and wrote the manuscript

2. Salamah Mohammad Alwahsh: assisted to interpret the data and improved the manuscript

3. Margret Rave-Fränk: optimized the radiation protocol, performed the radiation experiment

4. Clemens Friedrich Hess: assisted to interpret the data and improved the manuscript

5. Hans Christiansen: optimized the radiation protocol, performed the radiation experiment

6. Giuliano Ramadori: assisted to interpret the data; financial support 
7: Ihtzaz Ahmed Malik: research theme design, data interpretation, improved the manuscript 


\title{
Original Article \\ Hepatic fat accumulation and regulation of FAT/CD36: an effect of hepatic irradiation
}

\author{
Gesa Martius ${ }^{1}$, Salamah Mohammad Alwahsh ${ }^{1}$, Margret Rave-Fränk², Clemens Friedrich Hess ${ }^{2}$. \\ Hans Christiansen ${ }^{2 *}$, Giuliano Ramadori ${ }^{1}$, Intzaz Ahmed Malik ${ }^{1}$ \\ Departments of ${ }^{2}$ Gastroenterology and Endocrinology, ${ }^{2}$ Radiotherapy and Radiooncology, University Medical \\ Center Goettingen, D-37075 Goettingen, Germany. *Current address: Department of Radiation Oncology, Med- \\ izinische Hochschule Hannover, Carl-Neuberg-Straße, 30625 Hannover, Germany. \\ Received June 3, 2014; Accepted July 16, 2014; Epub July 15, 2014; Published August 1, 2014
}

Abstract: Irradiation is known to induce inflammation and affect fat metabolic pathways. The current study investi. gates hepatic fat accumulation and fatty acid transportation in a rat model of single dose liver irradiation (25-Gy). Rat livers were selectively irradiated in-vivo (25-Gy), sham-irradiated rats served as controls. Hepatic lipids were studied by colorimetric assays in liver and serum. Intracellular lipids, protein and mRNA were studied by Nile red staining immunohistology, Western Blot analysis and RT.PCR in liver, respectively. Changes in FAT/CD36 expres. sion were studied in-vitro in a human monocyte cell line U937 after irradiation in presence or absence of infliximab (IFX). Nile Red staining of liver cryosections showed a quick $(12.48 \mathrm{~h}$ ) increase in fat droplets. Accordingly, hepatic triglycerides (TG) and free fatty acids (FFA) were elevated. An early increase ( $3 \cdot 6 \mathrm{~h})$ in the serum level of HDL.C. TG and cholesterol was measured after single dose irradiation followed by a decrease thereafter. Furthermore. expression of the fat transporter protein FAT/CD36 was increased, immunohistochemistry revealed basolateral and cytoplasmic expression in hepatocytes. Moreover, apolipoprotein-B100, $\cdot \mathrm{C} 3$ and enzymes (acetyl-CoA carboxylase. lipoprotein-lipase, carnitine-palmitoyltransferase, malonyl-CoA-decarboxylase) involved in fat metabolism were in. duced at $12-24 \mathrm{~h}$. Early activation of the NFk $\beta$ pathway $(\mathrm{IKB} \alpha)$ by TNF- $\alpha$ was seen, followed by a significant elevation of serum markers for liver damage (AST and GLDH). TNF- $\alpha$ blockage by anti-TNF- $\alpha$ in cell culture (U937) prevented the increase of FAT/CD36 caused by irradiation. Selective liver irradiation is a model for rapid induction of steatosis hepatis and fat accumulation could be triggered by irradiation-induced inflammatory mediators (e.g. TNF. $\alpha$ ).

Keywords: Liver, fat accumulation, FAT/CD36, inflammation, cytokines, radiation

Introduction

The liver regulates the metabolism of glucose proteins and fat. Storage of lipids occurs in hepatocytes as free fatty acids (FFA), triglycerides (TG) and cholesterol, whereby the liver is the main organ which synthesizes TGs and cholesterol [1].

As the liver is the pivotal metabolic organ, hepatic impairment may have serious conse quences.

Hepatic steatosis occurs whenever there is an imbalance among the uptake, synthesis, oxida. tion and secretory pathways of fatty acid metabolism [2]. Sources of fatty acids for hepatic TG synthesis are derived from the plas. ma non-esterified fatty acids (NEFA) pool and from de novo hepatic lipogenesis (DNL), mainly from glucose [1]. Moreover, a fat-enriched diet also contributes to elevate liver TG and fatty acids.

Fat homeostasis is controlled by a number of factors including different enzymes, transcription factors, membrane and/or intracellular proteins involved in transport, synthesis and degradation of fat [3].

Free fatty acids are taken up by hepatocytes via transport proteins like the transporter fatty acid translocase (FAT/CD36), fatty acid transport protein-1 (FATP-1) and liver fatty acid binding protein (L-FABP) [4]

FAT/CD36 is a membrane bound glycoprotein present on platelets, mononuclear phagocytes, 
Table 1. Sequence of the primers used for the realtime PCR

\begin{tabular}{|c|c|c|}
\hline Name & Forward primer & Reverse primer \\
\hline Acetyl-CoA Carboxylase (ACC-2) & 5'ATGGTCATGCGTTACGGCA-3 & $5^{\circ}$-CGGACTCGTTGGTGATGAAGA-3' \\
\hline Apolipoprotein B100 (ApoB100) & 5'-CATGTGTCTGAAGCCATCTG-3' & 5'-ACTTGGTGATACCTCCTCTG-3' \\
\hline Apolipoprotein C3 (ApoC3) & 5'ACAATCGCTTCAAATCCCTG-3' & 5'-ACGGCTCAAGAGTTGGTGTT-3' \\
\hline$\beta$-Actin & 5'-GAAATCGTGCGTGACATTAAAGAG-3' & 5'-GCGGCAGTGGCCATCTC-3' \\
\hline Carnitine Palmitoyltransferase $1 \alpha$ (CPT- $1 \alpha)$ & 5'-CGGTTCAAGAATGGCATCATC-3' & $5^{\prime}$-TCACACCCACCACCACGAT- $3^{\prime}$ \\
\hline Fatty Acid Transporter/Cluster of Differentiation 36 (FAT/CD36) & $5^{\circ}$-GATGTGGAACCCATAACTGGA-3' & 5'-CTTTCTCATCGCCAATGGTC-3' \\
\hline Fatty Acid Transport Protein-1 (FATP-1) & 5'-CGCTTCTCAATGTCAACCTG-3' & 5'-AAATAGCCGATCATCCATGC- $3^{\circ}$ \\
\hline Liver Fatty Acid Binding Protein (L-FABP) & 5'CTGAGGACCTCATCCAGAA-3' & 5'-CACCCTCCATCTTAACCAC-3' \\
\hline Liver Lipoprotease (LPL) & 5-CCCTACAAAGTATTCCATTACC- $3^{\prime}$ & $5^{\circ}$-CCGTGTAAATCAAGAAGGAG-3. \\
\hline Malonyl-CoA Decarboxylase (MCOAD) & 5'AAGAGTGCCCTCCGTCTGAAA-3' & $5^{\prime}$-GCTTTATGAGGAAGGTGCCGA-3' \\
\hline Mitofusin-2(Mtf-2) & 5'-AGGAAATTGCTGCCATGAAC-3' & 5'-GTCTCTCTCGGTGCAGGTC-3' \\
\hline Tumor Necrosis Factor $\alpha$ (TNF- $\alpha$ ) & 5'ACAAGGCTGCCCCGACTAT-3' & 5'-CTCCTGGTATGAAGTGGCAAATC- $3^{\prime \prime}$ \\
\hline Ubiquitin (Ubc) & $5^{\circ}$-CACCAAGAAGGTCAAACAGGAA-3' & 5'-AAGACACCTCCCCATCAAACC- $3^{\prime}$ \\
\hline
\end{tabular}
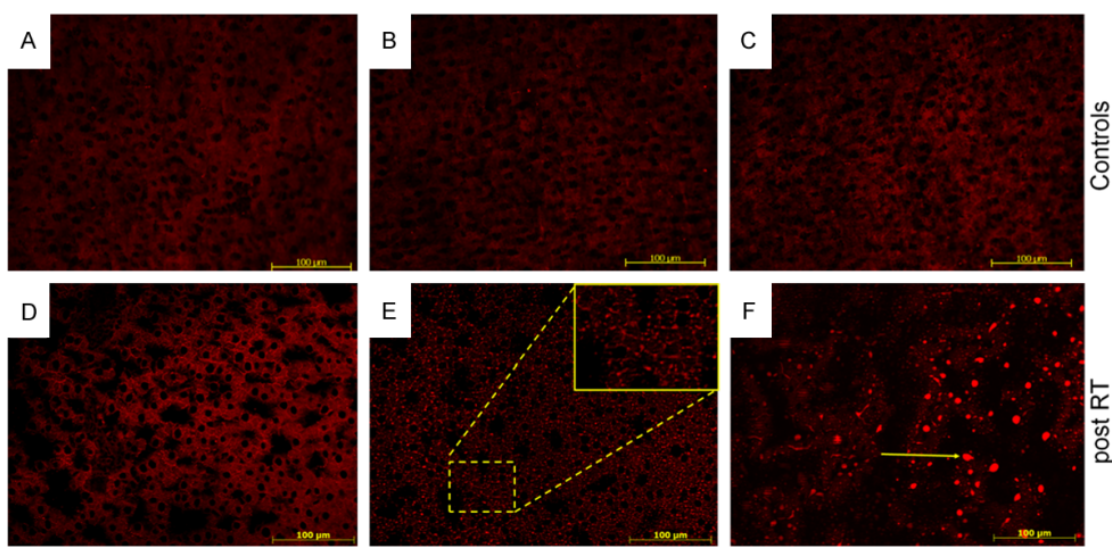

Figure 1. Fluorescent staining of intracellular fat with Nile Red dye in cryosections of livers of 12,24 and $48 \mathrm{~h} \mathrm{sham}$. irradiated controls (A-C) and irradiated rats (D-F). The intracellular accumulation of fat in droplets increased with time. Magnified area is shown in picture E. Arrow in picture F shows lipid droplet. Sections were $5 \mu \mathrm{m}$ thick. Results show representative picture of three animals and six slides per time point (original magnification, $\times 200$ ).

adipocytes, hepatocytes, and myocytes $[3,5]$. A ligand-specific aspect of FAT/CD36 signalling involves its capacity to deliver biologically active lipids to cells. FAT/CD36 is also known to have functions on adipocytes, muscle cells, enterocytes, and hepatocytes as a facilitator of long chain fatty acid transport [6]. There is evidence that fatty acids or oxidized, bind to FAT/ CD36, however, the exact mechanism of fatty acid uptake into liver cells remains unclear [7].

In several animal models, ablation of FAT/ CD36-mediated lipid uptake into muscle or liver prevented lipotoxicity [8]. In models in which FAT/CD36 was specifically induced in the liver by pharmacologic means or cDNA trans. duction, it may lead to steatosis, which can also contribute to metabolic disorders [7].

In addition, carnitine palmitoyltransferase $1 \alpha$ (CPT1 $\alpha$ ) is a mitochondrial membrane-localized enzyme that catalyses the key reaction in the metabolism of long chain fatty acyl-CoA by transporting long chain fatty acids from the cytoplasm into mitochondria [9]. Malonyl-CoA decarboxylase (MCOAD) is highly expressed in the liver [9] and also takes part in the degradation of fatty acids.

Radiation therapy involves the use of highenergy rays to treat local or regional malignancies either alone or in combination with modali-

Int J Clin Exp Pathol 2014;7(8):5379-5392 

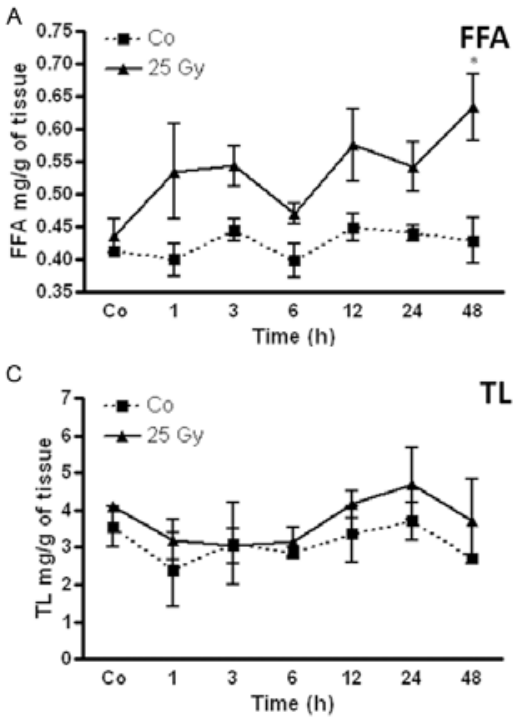

ties such as chemotherapy or surgery. Therapeutic radiation causes both, acute and chronic toxicity in normal tissues [10]. Indeed. radiation-induced liver disease (RILD) is a serious clinical complication [11], mainly due to vessel damage. Radiation-induced inflamma tion is known to be mediated by cytokines [12] Furthermore, free radicals such as reactive oxygen species (ROS) are generated after irradiation in irradiated tissue, and cells which are chemically very active are prone to oxidative stress [10]. Moreover, ionizing radiation is recently reported to alter the gene or protein expression of fat metabolism pathway in parallel to accumulation of fat in adipose tissue of rat [13]. However, effect of targeted liver radia tion has been not investigated so far.

In our previous work, we have shown that single-dose irradiation of rat liver induces periportal inflammation and changes the gene expression of proteins including those of iron metabolism and inflammatory mediators [14]

As molecular mechanisms underlying inflam matory events during obesity are poorly defined, we extended our previous knowledge and investigated whether single dose liver irradiation could trigger the intracellular fat accumulation in the liver. Additionally, we analysed the changes in gene expression of fat metabo lism proteins after irradiation.

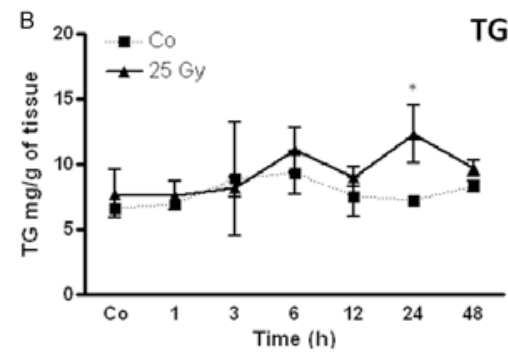

Figure 2. Amount of (A) free fatty acids (FFA) (B) triglyceride (TG) and (C) total lipids (TL) concen. tration in the liver tissue lysate of irradiated rat liver compared to the sham-irradiated controls for each time points. Values on y-axis are concentration values of FFA. TG and TL measured compared to sham-irradiated controls. Results represent mean value tS. M. of five animals. $\star p<0.05$.

\section{Material and methods}

\section{Materials}

All chemicals used, were of analytical grade and purchased from commercial sources as follows: real-time polymerase chain reaction (PCR) primers, M-MLV reverse transcriptase, reverse transcription buffer, $0.1 \mathrm{M}$ dithiothreitol (DTT), Platinum SYBR green GPCR UDG mix were from Invitrogen (Carlsbad, USA); dNTPs, Protector RNase inhibitor. Klenow enzyme, primer oligo (dT) 15 for complementary DNA (cDNA) synthesis, and Salmon sperm DNA were from Roche (Penzberg, Germany); Hybond N nylon membranes were purchased from Amersham Pharmacia Biotech (Amersham, UK). 4.6-diamidino-2-phenylindole (DAPI) from Southern Biotech (Birmingham, USA). All other reagents and chemicals were from SigmaAldrich (St Louis, USA) or Merck (Darmstadt, Germany)

\section{Animal model}

Male Wistar rats of about 200-250 gram body weight were purchased from Harlan-Winkelmann (Brochen, Germany). A rat model for selective liver irradiation was established using CT planned single organ irradiation as described before [15]. Briefly, a planning CT- scan

Int J Clin Exp Pathol 2014;7(8):5379-5392 

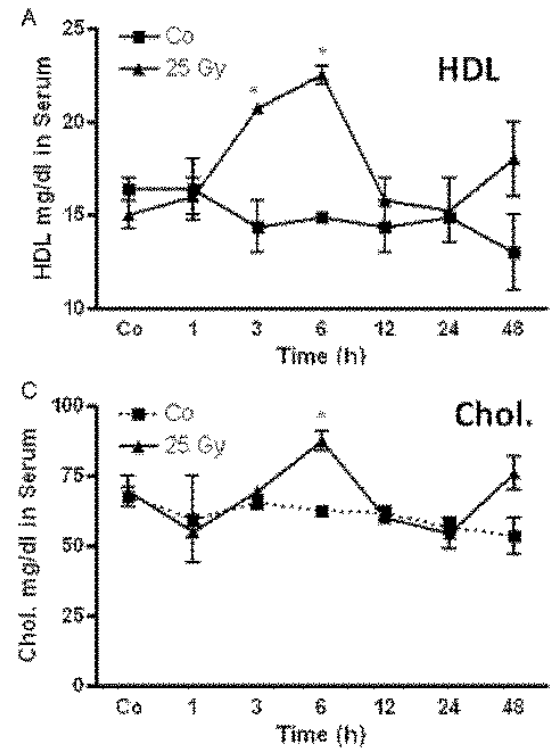

(Siemens, Eriangen. Germany) was done on each anesthetized rat i.p. $[90 \mathrm{mg} / \mathrm{kg}$ ketamine (Intervet, UnterschleiBheim, Germany). $7.5 \mathrm{mg} /$ $\mathrm{kg}$ xylazine $2 \%$ (Serumwerk Bernburg AG Bernburg/Saale, Germeny)] to delineate the livers of the animals. The margins of the liver were marked on the animal's skin, and a dose distribution was calculated. Livers were irradi. ated selectively with $6 \mathrm{MV}$ photons (dose rate of 2.4 Gy/min) using a Varian Clinac $\mathrm{C}$ accelera tor (Varian Medical Systems, Palo Alto, USA). A dose of 25-Gy was detivered using an AP/PA treatment technique. Sham-irradiated control animals were handled similarly but were not irradiated. Treated animals and sham-irradiated controls were killed humanely 1, 3, 6, 12, 24 and $48 \mathrm{~h}$ after irradiation. All animals received humane care in accordance to the German Law for the Protection of Animals and the institutional guidelines. The treatment of the rats, and the experiments were approved by the local committe on animal welfare

Histopathological examination

Unfixed cryostat liver sections ( 5 um) from irradiated rats and sham-irradiated controls were stained by Nite Red (Sigma-Aldrich. St. Louis, USA) to study the histology of iradiated-liver tissues compared to shamilradiated controls.

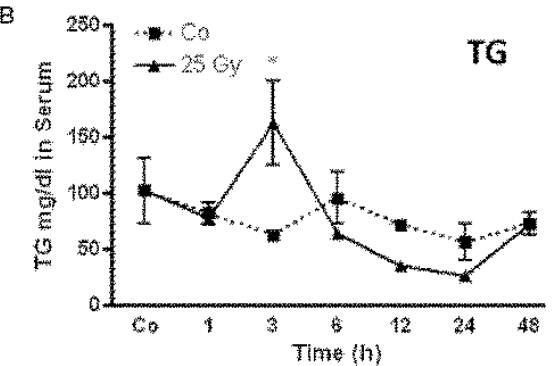

Figure 3. Changes in circulating high-density ipoprotein (HOL) (A) triglyceride (TG) (B) and cholesterol (chol) (C) in the serum of irradiated rat compared to the sham irradiated controls for each time points. Values on yaxis are serum-concentration of HDL. TG and chol measured compared to sham-irradiated controls. Results represent mean value \pm $S E M$ of five animals $* 0<0.05$

Nile Red-stained slides were observed by using an Axiovert $200 \mathrm{M}$ epiftuorescence microscope (Zeiss, Jena, Germany). Immunofluorescence staining was also performed as described before 14 f for FAJ/CD 36 by using a monocional antibody (Abcam, Cambridge, UK) and Atexa Fluor(B) 555 goat anti-rat modamin-coupled was used as secondary antibody (Invitrogen, Carlsbad, USA) Non-mmune serum was used as negative control.

Lipid profile and transaminase analysis in serum and iver tissue after irradiation

Btood samples and tiver tissues were collected from rats at the studied time points. The plasmalevels of TG, total cholesterol, and high-density lipoprotein containing cholesterol (HOL-C) and the activity of liver transaminases aspar. tate aminotransferase. (AST) and glutamate dehydrogenase (GLDH) were determined by uti. lizing the automated systems of the central leboratory of the institute of Clinical Chemistry in University Medical Centre Goettingen. Frozen liver portions (ca. $100 \mathrm{mg}$ ) were homogenized in 5\% Triton X-100 (Merck, Darmstadt, Germany) TGandFFAconcentrationsweredetermi. nedbycommerciallyavalablekits(BioAssaySyst: ems, Hayward, 15A).

Int J Clin Exp Pathol 2014,7(8):5379.5392 


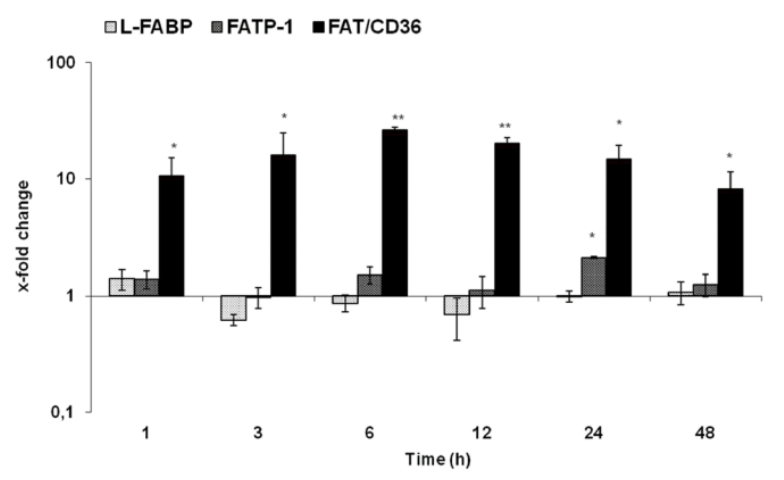

Figure 4. ART-PCR analysis of total RNA isolated from rat liver after irradiation. Data are shown as fold-changes in mRNA expression of fat transport proteins (LFABP, FATP-1, and FAT/CD36) at various time-points relative to sham-irradiated controls for each time-point. qRT-PCR was normalized by using two housekeeping genes: $\beta$-actin and ubiquitin. Results represent means \pm S.E.M. of five experiments; ${ }^{\star} P<0.05 \mathrm{n}=5$
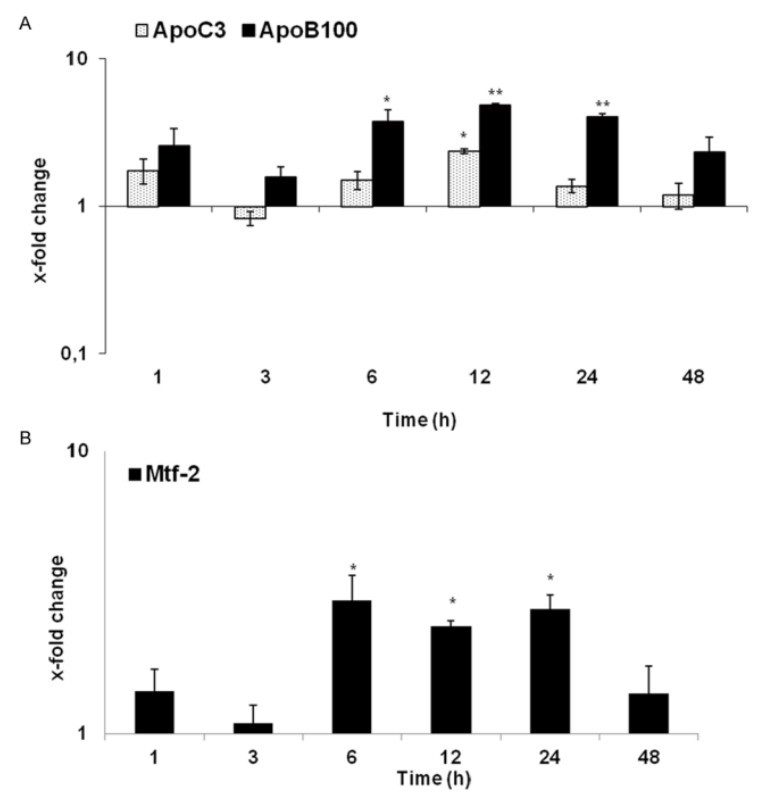

Figure 5. qRT-PCR analysis of total RNA isolated from rat liver after irradiation. Data are shown as fold-changes in mRNA expression of membrane proteins ApoC3, ApoC3 (A) and Mtf-2 (B), that are involved in fatty acid metabolism at various time-points relative to sham-irradiated controls for each time-point. QRTPCR was normalized by using two housekeeping genes: $\beta$-actin and ubiquitin. Results represent means \pm S.E.M. of five experiments; ${ }^{\star} P<0.05, n=5$.
Lipid quantity was analysed by the Bligh and Dyer method of lipid isolation using chloroform/methanol [16].

RNA isolation and real-time $P C R$ analysis

Total RNA from the livers of irradiated and sham-irradiated rats was isolated after homogenization in guanidine isothiocyanate (SigmaAldrich, St. Louis, USA) by the $\mathrm{CsCl}$ ultracentrifugation method as described previously [17].

For real-time $\mathrm{PCR}$, reverse transcription of the extracted RNA samples was performed using a Superscript kit from Invitrogen (Carlsbad, USA). Briefly, cDNA was generated by reverse transcription of $1 \mu \mathrm{g}$ of total RNA using $100 \mathrm{nM}$ of dNTPs, $50 \mathrm{pM}$ of primer oligo dT15, $200 \mathrm{U}$ of moloney murine leukaemia virus reverse transcriptase (M-MLV $\mathrm{RT}), 16 \mathrm{U}$ of protector RNase inhibitor in RT buffer and $2.5 \mu \mathrm{l}$ of $0.1 \mathrm{M}$ DTT; real time PCR was performed using an $\mathrm{ABI}$ prism 7700 sequence detection system (Applied Biosystems, Darmstadt, Germany) as described elsewhere [14].

$\beta$-actin and ubiquitin were used as housekeeping genes. The results were normalized to the housekeeping gene and fold change expression was calculated using threshold cycle (Ct) values. Primer sequences are given in Table 1. All primers were synthesized by Invitrogen (Carlsbad, USA). 


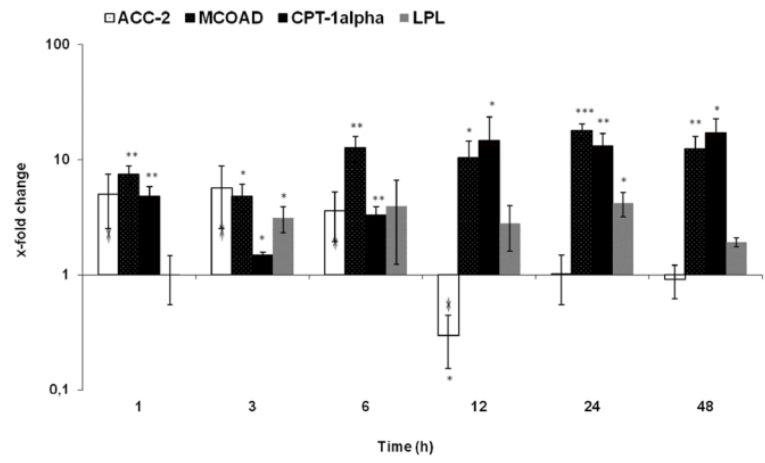

Figure 6. qRT-PCR analysis of total RNA isolated from rat liver after irradiation. Data are shown as fold-changes in mRNA expression of membrane proteins that are involved in fatty acid metabolism. Fold-change expressions of ACC-2 MCOAD, CPT- $1 \alpha$ and LPL at various time-points relative to sham-irradiated controls for each time-point. qRT-PCR was normalized by using two housekeeping genes: $\beta$-actin and ubiquitin. Results represent means \pm S.E.M. of five experiments: $\star p<0.05, \mathrm{n}=5$

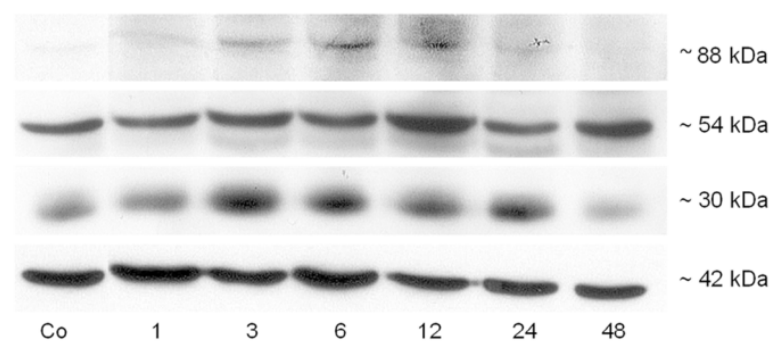

Figure 7. Western blot analysis of total protein from rat liver by using anti-FAT/ CD36 after irradiation at different time points. Three bands, $\sim 88$ (active isoform), $\sim 54$ (inactive isoform) and $\sim 30 \mathrm{kDa}$ (short isoform) were detected after irradiation in rat liver. â-actin $(\sim 42 \mathrm{kDa})$ was used as a loading control. Results are representative of three experiments.

Protein extraction from liver tissue and cells

About $50 \mathrm{mg}$ frozen tissue or cells were homog enized with an Ultra-turrax TP 18/10 (ColeParmer, Vernon Hills, USA), three times for $10 \mathrm{~s}$ each, in 10 vol 50 mM TRIS- $\mathrm{HCl}$ buffer, $\mathrm{pH} 7.4$ containing $150 \mathrm{mM}$ sodium chloride, $1 \mathrm{mM}$ EDTA, 1\% Triton X-100, $1 \mathrm{mM}$ phenylmethane sulfonyl-fluoride (PMSF), $1 \mathrm{mM}$ benzamidine, 1 $\mathrm{mg} / \mathrm{ml}$ leupeptin, $10 \mathrm{mM}$ chymostatin, $1 \mathrm{mg} /$ $\mathrm{ml}$ antipain, and $1 \mathrm{mg} / \mathrm{ml}$ pepstatin $\mathrm{A}$. The entire procedure was carried out at $4^{\circ} \mathrm{C}$. Crude homogenates were passed five times through a $22 \mathrm{G}$ needle attached to a syringe and centrifuged for $5 \mathrm{~min}$ at $10,000 \mathrm{~g}$, at $4^{\circ} \mathrm{C}$. The protein concentration was determined in supernatants by using the BCA (bicinchoninic acid) protein assay reagent kit (Pierce, Rockford. USA). Aliquots of the homogenates were stored at $-20^{\circ} \mathrm{C}$ until further used for Western blot analysis.

Western blot analysis

Samples of $50 \mu \mathrm{g}$ proteins were applied per well and subjected to polyacrylamide gel electrophoresis using NuPAGE $4-12 \%$ Bis-Tris Gel (Invitrogen, Carlsbad. USA) under reducing conditions as described previously [18]. After electrophoresis, the proteins were transferred to Hybond-ECL (enhanced chemiluminescence) nitrocellulose membranes. Immunodetection was performed according to the ECL Western blotting protocol described before [18]. The antibodies used in this study were, monoclonal anti- FAT/CD36 (Abcam, Cambridge, UK), polyclonal anti-IkB $\alpha$ (Abcam, Cambridge, UK), monoclonal anti-TNF- $\alpha$ (Abcam, Cambridge, UK). $\beta$-actin (Sigma-Aldrich, St. Louis, USA) was used for equal loading.

Culture and treatment of promonocytic cell line U-937

U-937 promonocytic cells were seeded at $2 \times 10^{5}$ cells $/ \mathrm{ml}$ in RPMI 1640 medium containing $10 \%(\mathrm{~V} / \mathrm{v})$ heat-inactivated fetal calf serum. $2 \mathrm{mM} / \mathrm{L}$ L-glutamine, $1 \mathrm{mM} / \mathrm{I}$ sodium pyruvate and $1 \mathrm{mM}$ of non-essential amino acids, and cultured at $37^{\circ} \mathrm{C}$ in an atmosphere of $95 \%$ air. $5 \% \mathrm{CO}_{2}$ as described previously [19]. In a second set of experiments, U-937 promonocytic cells were administrated with irradiation ( $8 \mathrm{~Gy}$ ) or stimulated with either human TNF- $\alpha$ (10 ng/ $\mathrm{ml)}$ (Roche. Penzberg. Germany), in the presence of antibody against human TNF- $\alpha$ inflix-

Int J Clin Exp Pathol 2014;7(8):5379-5392 

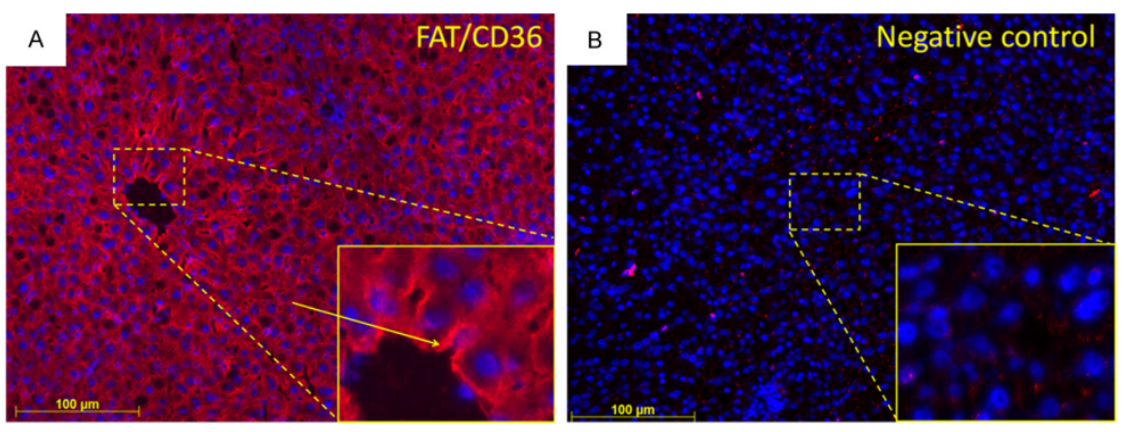

Figure 8. Immunofluorescent staining of liver sections with monoclonal antibody directed against FAT/CD36 fol. lowed by fluorescent immunodetection with labeled secondary antibody (red). A. FAT/CD36-positive cells with an arrow which points to basolateral localization, inlet shows higher magnification; B. Negative control, inlet shows higher magnification. Nuclear counterstaining was done with DAPI. Results shows representative picture of three animals (original magnification, $\times 200$ )

imab (Remicade, $1000 \mu \mathrm{g} / \mathrm{ml}$ ) (MSD, Munich, Germany).

Statistical analysis

The data were analysed using Graph pad Prism 4 software (San Diego, USA). All experimental errors are shown as S.E.M. Statistical significance was calculated by student T-test. Significance was accepted at $* P<0.05$.

\section{Results}

Accumulation of fat content in rat liver after irradiation

Nile Red staining showed an increase in fat droplets in cryosections of irradiated (Figure 1D-F) rat liver after 12, 24 and $48 \mathrm{~h}$. Fat droplets were mainly stained red within hepatocytes and were increasing in size after irradiation in comparison to corresponding sham-irradiated (A-C) control. The maximum fat droplet accumulation was detected at $48 \mathrm{~h}$ after irradiation in rat liver (Figure 1F)

Change in free fatty acid (FFA), triglyceride (TG) and total lipids (TL) level in rat liver after irradiation

An early $(1 \mathrm{~h})$ increase in the FFA level was detected after irradiation compared to shamirradiated controls in rat liver. The FFA remained above control level throughout the course of the study with a maximum increase at $48 \mathrm{~h}$
$(0.63 \pm 0.05 \mathrm{mg} / \mathrm{g}$ vs. control $0.43 \pm 0.035$ $\mathrm{mg} / \mathrm{g})$

An elevated pattern for triglycerides (TG) was also observed in rat livers with a peak at $24 \mathrm{~h}$ $(12.4 \pm 2.2 \mathrm{mg} / \mathrm{g}$ vs. control $7.3 \pm 0.3 \mathrm{mg} / \mathrm{g})$ after irradiation compared to sham-irradiated control rats. However, only minor changes were measured in total lipid content after irradiation (Figure 2).

Change in high-density lipoprotein (HDL), triglyceride (TG) and cholesterol (chol) levels in rat serum after irradiation

The HDL level was significantly increased after irradiation compared to sham-irradiated controls $(17 \pm 0.1 \mathrm{mg} / \mathrm{dl})$ in rat liver. The maximum increase was found at $6 \mathrm{~h}(22+0.5 \mathrm{mg} / \mathrm{dl})$ followed by decrease after $24 \mathrm{~h}$. A similar pattern was also observed for cholesterol with a maximum at $6 \mathrm{~h}(87.5 \pm 3.5 \mathrm{mg} / \mathrm{dl}$ vs. control $67 \pm$ $3.5 \mathrm{mg} / \mathrm{dl}$ ). A significant elevation of TG-serum levels was measured at $3 \mathrm{~h}(163 \pm 37.5 \mathrm{mg} / \mathrm{dl}$ vs. control $62.8 \pm 4.8 \mathrm{mg} / \mathrm{dl}$ ) in rat liver after single dose irradiation. The level of TG was reduced after $6 \mathrm{~h}$ and remained significantly below control level at $12 \mathrm{~h}(35 \pm 2.3 \mathrm{mg} / \mathrm{dl})$ and $24 \mathrm{~h}(26 \pm 3.5 \mathrm{mg} / \mathrm{dl})$ (Figure 3$)$.

Radiation-induced changes of fat metabolism transcripts in liver tissue

Using real-time PCR analysis, mRNA expression from irradiated liver tissue was examined at 1 ,

Int J Clin Exp Pathol 2014;7(8):5379-5392 

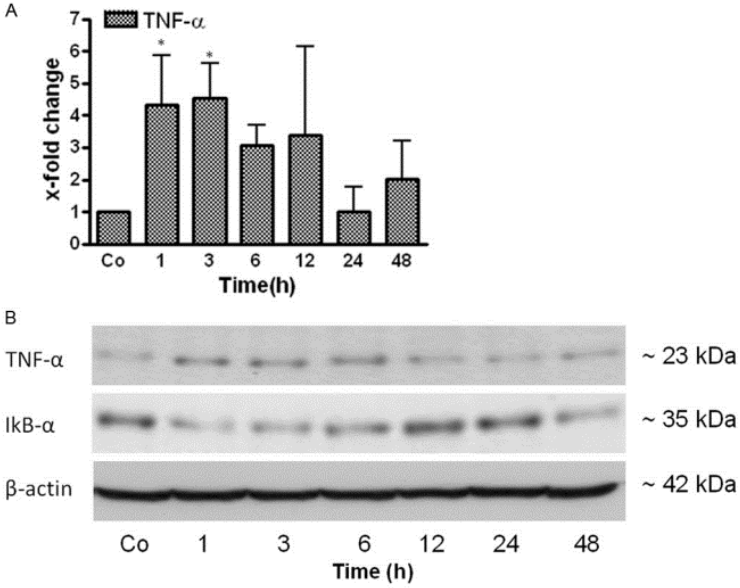

Figure 9. qRT-PCR and Western blot analysis from total RNA and total protein of rat liver after irradiation respectively. A. Fold change in mRNA expression of TNF- $\alpha$ in irradiated rat liver at different time points (1-48 h) related to sham irradiated controls for each time point. GRT-PCR was normalized by using two housekeeping genes: $\beta$-actin and ubiquitin $C$. Results represent mean value \pm S.E.M. of five animals $* p<0.05$. B. Western blot analysis of protein from rat liver after irradiation by using antibodies specific for TNF- $\alpha$ (upper) and lêBá (middle). $\beta$-actin (lower) was used as a loading control. Results are representative of three experiments.

theirexpressionremainedabove control levels until 48 h. Likewise, Apoc3 gene expression increased early with its peak at $12 \mathrm{~h}$ after irradiation. The strongest increase could be seen at 6. 12 and $24 \mathrm{~h}$ after treatment (Figure 5)

Enzymes: A quick ( $1 \mathrm{~h})$ and early change in gene expression of $A C C 2$, MCOAD and CPT-alpha was detected after irradiation. The most pronounced increase was detected in gene expression of MCOAD (17.8fold) at $24 \mathrm{~h}$ and CPT-alpha (17-folds) at $48 \mathrm{~h}$ and LPL (4.2-fold) at $24 \mathrm{~h}$. The expression of these three genes remained significantly upregulated throughout the course of the study. However, a significant reduction at $12 \mathrm{~h}$ was detected in the gene expression of ACC-2 (3.3-fold) (Figure 6).

3, 6, 12, 24 and $48 \mathrm{~h}$ after irradiation. Gene expression was normalized to corresponding sham-irradiated controls and compared to the expression of ubiquitin.

Fat transport proteins: An early (1 h) significant increase was detected in FAT/CD36 at mRNA level. The most significant upregulation was found at $6 \mathrm{~h}$ (26.4 folds) after irradiation. It remained significantly elevated until $48 \mathrm{~h}$ after irradiation. The increase of FAT/CD36 was high est after rat liver irradiation among all studied genes. Furthermore, a mild increase in the gene expression of FATP-1 and L-FABP was detected by RT-PCR (Figure 4)

Membrane proteins: The examined membrane proteins apolipoprotein C3 (ApoC3), apolipoprotein B100 (ApoB100) and mitofusin-2 (Mtf2) were up-regulated after irradiation at every measured time point. Gene expression of membrane proteins started to increase early after irradiation. The maximum upregulation was observed for Mtf-2 at $6 \mathrm{~h}$ ( 3 -fold) followed by ApoB100 at $12 \mathrm{~h}$ (4.8-fold) at transcript level
Changes in FAT/CD36 protein level in rat liver by western blot analysis

Western blot was performed to analyze the time dependent protein content in irradiated vs. sham irradiated control samples. It is known that FAT/CD36 is built as a non-active form of $54 \mathrm{kDa}$ and is then post-translational glycosylated to its active form of $88 \mathrm{kDa}$ [20]. The antibody detected 3 different antigens which are a $54 \mathrm{kDa}$, an $88 \mathrm{kDa}$ and a $30 \mathrm{kDa}$ protein. Similar to what was observed at RNA level. using antibody against FAT/CD36 in the irradiated liver tissue, an increased level of FAT/ CD36 was detected with a maximum at $12 \mathrm{~h}$ for the active and inactive form and a maximum at $3 \mathrm{~h}$ for the short isoform. The protein level of all isoforms of FAT/CD36 decreased after $12 \mathrm{~h}$ (Figure 7)

Localization of FAT/CD36 protein by immunofluorescent staining

Immunofluorescent staining of irradiated rat liver section with an antibody against FAT/CD36

Int J Clin Exp Pathol 2014:7(8):5379-5392 
A

AST

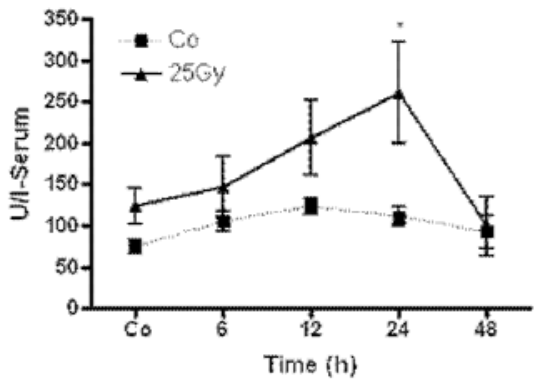

B GLDH

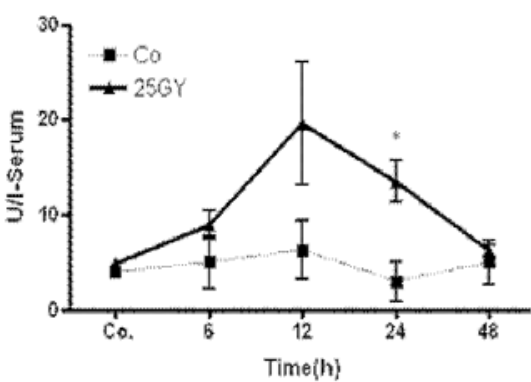

Figure 10. Measurement of aspartate transaminase (AST) and glutamate dehydrogenase (GLDH) concentrations in rat serum after single dose liver irradiation related to sham-irradiated controls for each time point. Results represent means \pm S.E.M. of five experiments: $* \rho<0.05, n=5$

was performed. A fluorescent signal for FAT/ CD36 was found in the basolateral membrane and the cytoplasm of hepatocytes in rat liver (Figure 8A). The expression of FAT/CD36 was equally distributed in the liver tissue. The negative controls showed no positive staining of FAT/CD36 (Figure 8B)

Real time PCR analysis of TNF- $\alpha$ in irradiated rat liver

The MRNA expression of TNF- $\alpha$, a major pro. inflammatory cytokine was analyzed in liver tis. sue at $1,3,6,12,24$ and $48 \mathrm{~h}$ after irradiation using real-time PCR analysis. A quick upregulation of TNF. $\alpha$ (4.3-fold) was detected after $1 \mathrm{~h}$ with a maximum at $3 \mathrm{~h}$. The gene expression of TNF- $\alpha$ then decreased (Figure 9A). The results were further confirmed at protein level by Western blot analysis using a specific antibody against membrane-bound TNF- $\alpha$. The protein level of TNF- $\alpha$ increased at 1-6 $\mathrm{h}$ with a decrease thereafter (Figure 9B)

Changes in protein expression of $1 k B \alpha$ in the rat liver after irradiation

Phosphorylation of the p65 subunit and degra. dation of $1 k B \alpha$ are known to be associated with activation of the NF-KB classical pathway [21] In order to analyze the activation of the NF-KB pathway, the transcription factor $1 \kappa B \alpha$ (subunit of NF-KB) was analyzed at protein level. IKBo protein was decreased at 1 and $3 \mathrm{~h}$. The level of I $\mathrm{KB} \alpha$ returned to basal level after wards in rat liver after irradiation (Figure 9B).
Serum level analysis of aspartate transaminase (AST) and glutamate dehydrogenase (GLDH)

The serum level of AST and GLDH both increased between 6 to $12 \mathrm{~h}$ with a maximum at 24 h after irradiation compared to sham-irradiated controls. The concentration of both enzymes decreased thereafter (Figure 10).

Modulation of FAT/CD36 protein expression in cultured human monocytic cell fine U-937

To investigate the role of TNF- $\alpha$ on FAT/CD36 gene regulation, human monocytic cells U-937 were treated with TNF- $\alpha$ and anti-TNF- $\alpha$ (Infliximab, IFX) in the presence or absence of irradiation. After preliminary experiments using different radiation doses (2, 8, 25 Gy) 8 Gy were chosen, as no greater effect was observed by using 25 Gy.

As previously reported [22], only the mature form of FAT/CD 36 at $>95 \mathrm{kDa}$ is detectable in unstimulated U937. Similarly, we have detected a $102 \mathrm{kDa}$ band by using the specific antibody against FAT/CD36. Furthermore, an increase in protein level of FAT/CD36 was revealed in $\mathrm{U}-937$ cells at $8 \mathrm{~h}$ to $24 \mathrm{~h}$ after TNF- $\alpha$ or irradiation-as compared to the anti-TNF- $\alpha$ (IFX)- and non-treated control cells. In addition, a syner. gistic effect on FAT/CD36 induction was observed when TNF- $\alpha$ was administered together with irradiation. The up-regulating effect of irradiation was decreased by addition

Int J Clin Exp Pathol 2014:7(8):5379-5392 


\section{Effect of irradiation on FAT/CD36}

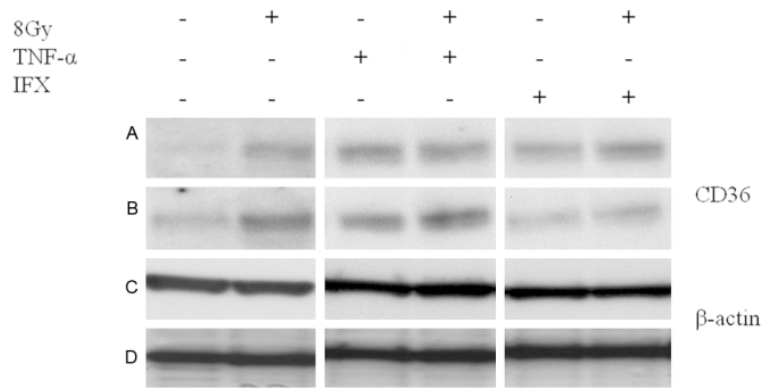

Figure 11. Western blot analysis of total protein isolated from human U-937 cell line by using antibody specific for FAT/CD36 ( 102 kDa, active form) after irradiation ( $8 \mathrm{~Gy}$ ) and/or tumor necrosis factor-alpha (TNF- $\alpha$ ) in the presence/abence of infliximab (IFX) at $8 \mathrm{~h}$ ( $\mathrm{A}$ and $\mathrm{C}$ ) and $24 \mathrm{~h}$ ( $\mathrm{B}$ and $\mathrm{D}$ ) â-actin $(\sim 42 \mathrm{kDa}$ ) was used as a loading control. Results are representative of three experiments.
These results were confirmed at protein level showing an increase in different isoforms of FAT/ CD36 after irradiation

Eventually the accumulation of lipid droplets into the hepatocytes results in hepatic steatosis, [7, 24] which may develop as a consequence of multiple dysfunctions such as alterations in $\beta$-oxidation, very low density lipoprotein secretion, and pathways involved in the synthesis of fatty acids [25] of anti-TNF- $\alpha$ (IFX) to the culture medium (Figure 11)

\section{Discussion}

Clinical and pathological studies revealed that radiation therapy can produce significant hepatic injury. Radiation-induced liver disease (RILD) has been one of the most important treatment-related complications of hepatic irradiation. The pathomechanisms of radiotherapyinduced hepatic toxicity are not clearly understood [23]

Previously, we showed liver inflammation caused by single-dose-irradiation [14] followed by some fat droplet in the liver by HE-staining method [15]. Therefore, the aim of this project was to ascertain if selective liver irradiation could increase the fat transport into the liver. Furthermore, we studied the changes of genes expression involved in fat transport

We found an increased fat accumulation by Nile red-staining at 24 and $48 \mathrm{~h}$ after liver irradiation. In parallel, TG and FFA levels were also elevated in liver tissue, confirming the accumulation of fat within the cells. An early increase (3-6 h) in serum HDL, TG and cholesterol levels was also found. According to the increased FFA and TG-levels, an increased expression of genes involved in fat metabolism such as ACC 2, LPL, Mtf-2, lipoproteins (ApoB100, ApoC3) and transport proteins (L-FABP FATP-1, FAT/ CD36) was detected at 1-48 $\mathrm{h}$ in liver tissue at mRNA level after irradiation. FAT/CD36 showed the highest increase among all studied genes.
The triacylglycerol content of hepatocytes is regulated by the activity of several fat metabolism proteins that facilitate hepatic fatty acid uptake, fatty acid synthesis, and esterification ('input') and hepatic fatty acid oxidation and triacylglycerol export ('output') [26]. ACC-2 regulates the metabolism of fatty acids [27]. An elevated level of ACC-2 in our study indicates de novo synthesis of fatty acids and at the same time an increased hydrolysis of fat observed by LPL upregulation which is in accordance to previous studies [28]

On the other hand, in order to transport fatty acids into hepatocytes, several proteins are necessary such as putative fatty acid transporter fatty acid translocase (FAT/CD36), fatty acid transport protein (FATP-1) and liver fatty acid binding protein (L-FABP) which provide the removal of long chain fatty acids from tissues [4, 29-31]

Expression of liver fatty acid binding protein (L-FABP) and transport protein FATP-1 (fatty acid transport protein-1) was least affected by irradiation. These proteins are known to play a role in fatty acid metabolism [32]. However, the role of these proteins in the liver is still not clear. The putative long chain fatty acid transporter FAT/CD36 showed the highest increase in the rat liver after irradiation. Previous studies reported a role of FAT/CD36 in the process of accumulation of triglycerides in the liver which could lead to steatosis [7, 33]. This observation might be most crucial to explain steatosis in our model.

Int J Clin Exp Pathol 2014:7(8):5379-5392 
Furthermore, a link between Apo100 and Apoc3 to increased TG has already been docu. mented. These proteins are also known to play a role in fat export [28]. An increased gene expression of these genes could be another reason for steatosis through impaired trans. port of fatty acids out of liver cells.

Irradiation is known to damage the mitochondrial part of cell [34]. Indeed, disturbance in the hepatic mitochondrial function contributes to hepatic lipid accumulation [35, 36]. Here we observed that the expression of genes involved in mitochondrial biogenesis such as carnitine palmitoyltransferase- $1 \alpha$ (CPT- $1 \alpha)$ and Mitofusin-2 (Mtf2) was upregulated. CPT- $1 \alpha$ is a mito chondrial transmembrane enzyme thought to be rate limiting for long-chain fatty acid entry into the mitochondria for $\beta$-oxidation [37-39] The enzyme malonyl-CoA decarboxylase (MOCAD) is highly expressed in the liver and also takes part in the degradation of fatty acids, it catalyses the decarboxylation of malonyl-CoA to acetyl-CoA [9]. CPT1 $\alpha$ and MCOAD are linked by malonyl-COA; this molecule can inhibit CPT1 $\alpha$ and finally the mitochondrial $\beta$-oxidation [37].

A highly increased expression of MCOAD and CPT-1 $\alpha$ found in the current study points to an altered fatty acid oxidation in the mitochondria due to high amounts of fatty acids within the cells.

Another important aspect of the current and our previous studies was the observation of inflammation with infiltration of neutrophil granulocytes around the portal area [14] and an increase of pro-inflammatory cytokines. mainly TNF. $\alpha$ in serum and liver in the same model [12]. Moreover, the upregulation of TNF- $\alpha$ both at RNA and protein level after irradiation can account for the intense induction of these fat import proteins (e.g. FAT/CD36), indi. cating a direct effect of the TNF- $\alpha$, in regulating fat import proteins. In fact, a link between steatosis and inflammation has already been well established [40]

TNF- $\alpha$ is a key player of inflammation and it acts mainly through its transcription factor nuclear transcription factor (NF)-KB which is a pivotal regulator of several genes involved in i.e. inflammation. Phosphorylation of the p65 subunit and the degradation of IkB $\alpha$ are known to be associated with activation of the NF-KB classical pathway $[21,41]$. Induction of TNF- $\alpha$ in parallel to reduction of $\mathrm{I} B \mathrm{~B} \alpha$ level in our study suggests an activation of NF-KB pathway by TNF- $\alpha$.

To address the question of whether an increase in FAT/CD36 after irradiation induced liver damage could also be due to the direct effect of inflammatory mediators (e.g. TNF- $\alpha$ ), a human monocytic cell line U937 (characteristics of macrophages) was therefore cultured and treated with the "major" pro-inflammatory cyto. kine (TNF- $\alpha$ ) Similarly to what is observed in the liver tissue after irradiation, an increase in protein expression of FAT/CD 36 was found after TNF- $\alpha$ and/or irradiation administration whereas such an increase was inhibited by the addition of anti-TNF- $\alpha$ into culture medium of U937.

These results are consistent with the view that IFX, by blocking soluble TNF- $\alpha$, inhibits FAT/ CD36 protein level, preventing the increase of FAT/CD36 caused by TNF- $\alpha$ and irradiation in our in vitro experiment, a prerequisite for fat transporter into tissue.

The observed effect of anti-TNF- $\alpha$ might contribute to a reduction of inflammatory process. es caused by irradiation and/or TNF- $\alpha$ in rat liver, suggesting that a change in gene-expression of FAT/CD36 is also induced by irradiation or/and irradiation induced cytokines.

The unique point of current model is to detect a rapid (within hours) fat accumulation in parallel to liver inflammation after selective single dose liver irradiation, as previously reported fat animal models require long duration (weeks) to establish. Furthermore, these models are also developed by different types of diets such as high-fat or fructose-diet [42-44] which is also difficult to quantify as administrated orally.

Taken together, our current study established a quick hepatic steatosis model by selective rat liver irradiation. Furthermore, transport of fat into the liver could be due to FAT/CD36 which is influenced by cytokines (e.g. TNF- $\alpha$ ) produced after irradiation. TNF- $\alpha$-mediated induction of FAT/CD36 was further confirmed by our in vitro experiments. Clinically, regulation of fat metab. olism could be an underestimated response in radiotherapy. Further understanding of the fat metabolism before and during radiotherapy

Int J Clin Exp Pathol 2014:7(8):5379-5392 
could help to understand hepatic lipid metabolism for the prevention and/or treatment of fat. associated disorders (e.g. Non-aicoholic fatty liver disease). However, prospective studies would need to be performed to correlate fat metabolism dynamics following irradiation to the clinical course of patients developing irradiation-related problems

\section{Acknowledgements}

This work was supported by grants from German Research Foundation "Deutsche Forschungsgemeinschaft (DFG Project MA $5488 / 2-1$ ). Further support was granted by the German Research Foundation and Open Access Publication Funds of the Göttingen University. We also like to thank Dr. Silke Cameron for language proof-reading.

\section{Disclosure of conflict of interest}

None.

Address correspondence to: Dr. Intzaz Ahmed Malik Department of Gastroenterology and Endocrinology. University Medical Center Göttingen, Robert-Koch Strasse 40, 37075 Göttingen, Germany. Tel: 0049 551-398902: Fax: 0049-551-396921: E-mail: i. malik@med.uni-goettingen.de

\section{References}

1] Donnelly KL, Smith $\mathrm{Cl}$, Schwarzenberg SJ, Jes surun J. Boldt MD and Parks EJ. Sources of fatty acids stored in liver and secreted via lipo proteins in patients with nonalcoholic fatty liver disease. J Clin Invest 2005: 115: 1343 1351.

[2] Tilg $\mathrm{H}$ and Moschen AR. Evolution of inflamma tion in nonalcoholic fatty liver disease: the mu tiple parallel hits hypothesis. Hepatology 2010 52: $1836 \cdot 1846$

[3] Silverstein RL and Febbraio M. CD36, a scav enger receptor involved in immunity, metabolism, angjogenesis, and behavior. Sci Signal 2009; 2: re3

[4] Storch $J$ and Thumser AE. The fatty acid trans port function of fatty acid-binding proteins. Bio chim Biophys Acta 2000: 1486: $28-44$

(5) Zhang $X$. Fitzsimmons RL, Cleland LG. Ey PL. Zannettino AC. Farmer EA. Sincock $P$ and Mayrhofer G. CD36/fatty acid translocase in rats: distribution. isolation from hepatocytes. and comparison with the scavenger receptor SR-B1. Lab Invest 2003: 83: $317 \cdot 332$

[6] Coburn CT, Knapp FF Jr. Febbraio M, Beets AL. Silverstein RL and Abumrad NA. Defective up take and utilization of long chain fatty acids in muscle and adipose tissues of $\mathrm{CD} 36$ knockout mice. J Biol Chem 2000; 275: 32523-32529.

[7] Zhou J, Febbraio M. Wada T, Zhai Y, Kuruba R. He J, Lee JH. Khadem S, Ren S, LiS, Silverstein RL and Xie W. Hepatic fatty acid transporter Cd36 is a common target of LXR. PXR, and PPARgamma in promoting steatosis. Gastroen. terology 2008; $134: 556-567$.

[8] Yang J. Sambandam N. Han X. Gross RW. Courtois $M$. Kovacs A. Febbraio $M$. Finck $B N$ and Kelly DP. CD36 deficiency rescues lipotoxic cardiomyopathy. Circ Res 2007: 100: 1208-1217.

[9] Dyck JR. Berthiaume LG. Thomas PD, Kantor PF. Barr AJ. Barr R. Singh D. Hopkins TA. Voilley $N$. Prentki $M$ and Lopaschuk GD. Characterization of rat liver malonyl-COA decarboxylase and the study of its role in regulating fatty acid me. tabolism. Biochem J 2000; 350: 599-608.

[10] Citrin D. Cotrim AP, Hyodo F. Baum BJ, Krishna $\mathrm{MC}$ and Mitchell JB. Radioprotectors and mitigators of radiation-induced normal tissue injury. Oncologist 2010: 15: 360-371.

[11] Shim SJ. Seong J, Lee IJ. Han KH. Chon CY and Ahn SH. Radiation-induced hepatic toxicity after radiotherapy combined with chemotherapy for hepatocellular carcinoma. Hepatol Res 2007: 37: 906-913

[12] Christiansen H. Sheikh N. Saile B. Reuter F. Rave-Frank M. Hermann RM, Dudas J. Hille A. Hess CF and Ramadori G. X-Irradiation in rat liver: consequent upregulation of hepcidin and downregulation of hemojuvelin and ferroportin-1 gene expression. Radiology 2007: 242: 189.197.

[13] Jo SK. Seol MA. Park HR. Jung $U$ and Roh $C$. lonising radiation triggers fat accumulation in white adipose tissue. Int J Radiat Biol 2011: 87: $302 \cdot 310$

[14] Malik IA, Moriconi F, Sheikh N. Naz N. Khan S. Dudas J. Mansuroglu T. Hess CF, Rave-Frank $M$, Christiansen $\mathrm{H}$ and Ramadori $\mathrm{G}$. Single. dose gamma-irradiation induces up-regulation of chemokine gene expression and recruit. ment of granulocytes into the portal area but not into other regions of rat hepatic tissue. Am J Pathol 2010; 176: 1801-1815.

[15] Christiansen $H$. Batusic D Saile B. Hermann RM. Dudas J, Rave-Frank M, Hess CF, Schmidberger $\mathrm{H}$ and Ramadori $\mathrm{G}$. Identification of genes responsive to gamma radiation in rat hepatocytes and rat liver by CDNA array gene expression analysis. Radiat Res 2006: 165: 318-325.

[16] Bligh EG and Dyer WJ. A rapid method of total lipid extraction and purification. Can J Biochem Physiol 1959: 37: 911.917.

[17] Naz N. Moriconi F. Ahmad S. Amanzada A. Khan S, Minm S. Ramadori G and Malik IA. Fer.

Int J Clin Exp Pathol 2014;7(8):5379.5392 
ritin $\mathrm{L}$ is the sole serum ferritin constituent and a positive hepatic acute-phase protein. Shock 2013: 39: $520-526$

[18] Ahmad S, Moriconi F, Naz N. Sultan S, Sheikh $\mathrm{N}$. Ramadori $\mathrm{G}$ and Malik IA. Ferritin L and Ferritin $\mathrm{H}$ are differentially located within hepatic and extra hepatic organs under physiological and acute phase conditions. Int I Clin Exp Pathol 2013: 6: 622.629.

19] Amanzada A Moriconi F. Mansuroglu T Cameron S. Ramadori $G$ and Malik $A$. Induction of chemokines and cytokines before neutrophils and macrophage recruitment in different re gions of rat liver after TAA administration. Lab Invest 2014: 94: 235.47

[20] Lauzier B. Merlen C, Vaillant F. MCDuff J. Bouchard B. Beguin PC, Dolinshy VW. Foisy S Villeneuve LR. Labarthe F. Dyck JR. Allen BG, Charron $\mathrm{G}$ and Des RC. Post-translational mod ifications, a key process in $\operatorname{CD} 36$ function: les sons from the spontaneously hypertensive rat heart. J Mol Cell Cardiol 2011: 51: 99-108.

[21] DiDonato JA, Mercurio F and Karin M. NF-kap$\mathrm{paB}$ and the link between inflammation and cancer. Immunol Rev 2012; 246: 379-400.

[22] Gruarin P. Sitia R and Alessio M. Formation of one or more intrachain disulphide bonds is re quired for the intracellular processing and transport of CD36. Biochem J 1997: 328:635 642

23] Pan CC Kavanagh BD Dawson LA, Li XA, Das SK. Miften $M$ and Ten Haken RK. Radiation associated liver injury. Int I Radiat Oncol Biol Phys 2010: 76: \$94-100

24] Tiniakos DG, Vos MB and Brunt EM. Nonalco holic fatty liver disease: pathology and patho genesis. Annu Rev Pathol 2010: 5: 145-171.

[25] Buettner R. Parhofer KG. Woenckhaus M. Wrede CE, Kunz-Schughart LA, Scholmerich and Bollheimer LC. Defining high-fat-diet rat models: metabolic and molecular effects of different fat types. J Mol Endocrinol 2006; 36 485-501.

[26] Nguyen P. Leray V. Diez M. Serisier S. Le BJ. Siliart $B$ and Dumon $\mathrm{H}$. Liver lipid metabolism. J Anim Physiol Anim Nutr (Berl) 2008: 92: 272 283.

27] Abu-Elheiga L. Wu H Gu $Z$ Bressler $R$ and Wakil SJ. Acetyl.COA carboxylase $2 \%$ mutant mice are protected against fatty liver under high-fat, high-carbohydrate dietary and de novo lipogenic conditions. J Biol Chem 2012: 287: 12578 -12588.

[28] Degrace P, Moindrot B, Mohamed I, Gresti J, Du ZY. Chardigny JM. Sebedio JL and Clouet P. Upregulation of liver VLDL receptor and FAT/ CD36 expression in LDLR\% apoB100/100 mice fed trans-10.cis-12 conjugated linoleic acid. J Lipid Res 2006; 47: 2647-2655.
[29] Grefhorst A, Elzinga BM, Voshol PJ, Plosch T, Kok T Bloks Vw, van der Sluijs FH, Havekes LM. Romijn JA, Verkade HJ and Kuipers F. Stim. ulation of lipogenesis by pharmacological activation of the liver $X$ receptor leads to production of large, triglyceride-rich very low density lipoprotein particles. I Biol Chem 2002: 277 : $34182 \cdot 34190$

[30] Motojima K, Passilly P. Peters JM, Gonzalez F] and Latruffe N. Expression of putative fatty acid transporter genes are regulated by peroxisome proliferator-activated receptor alpha and gamma activators in a tissue- and inducer-specific manner. J Biol Chem 1998: 273: 16710. 16714.

[31] Oyama Y. Takeda T. Hama H, Tanuma A, lino N. Sato K. Kaseda R. Ma M. Yamamoto T. Fujii H, Kazama JJ, Odani S, Terada Y, Mizuta K, Gejyo $F$ and Saito $A$. Evidence for megalin-mediated proximal tubular uptake of L.FABP, a carrier of potentially nephrotoxic molecules. Lab Invest 2005: 85: 522.531.

[32] Coe NR and Bernlohr DA. Physiological properties and functions of intracellular fatty acidbinding proteins. Biochim Biophys Acta 1998: 1391: 287.306

[33] Koonen DP, Jacobs RL. Febbraio M, Young ME. Soltys $\mathrm{CL}$. Ong $\mathrm{H}$. Vance DE and Dyck JR. Increased hepatic $\mathrm{CD} 36$ expression contributes to dyslipidemia associated with diet-induced obesity. Diabetes 2007; 56: 2863-2871.

[34] Gupta D. Arora R, Garg AP, Bala M and Goel HC. Modification of radiation damage to mitochondrial system in vivo by Podophyllum hexandrum: mechanistic aspects. Mol Cell Biochem 2004: 266: 65.77

[35] Perez-Carreras M. Del HP. Martin MA. Rubio JC. Martin A, Castellano G, Colina F. Arenas J and Solis-Herruzo JA. Defective hepatic mitochondrial respiratory chain in patients with nonalcoholic steatohepatitis. Hepatology 2003; 38 : 999-1007

[36] Rector RS. Thyfault JP, Uptergrove GM, Morris EM. Naples SP. Borengasser SJ. Mikus CR. Laye MJ, Laughlin MH, Booth FW and Ibdah JA. Mitochondrial dysfunction precedes insulin resistance and hepatic steatosis and contributes to the natural history of non-alcoholic fatty liver disease in an obese rodent model. 1 Hepatol 2010: 52: 727.736

[37] Akkaoui M, Cohen I, Esnous C, Lenoir V. Sournac M. Girard $J$ and Prip-Buus $C$. Modulation of the hepatic malonyl-CoA-carnitine palmitoyltransferase $1 \mathrm{~A}$ partnership creates a metabolic switch allowing oxidation of de novo fatty acids. Biochem J 2009: 420: 429-438.

[38] Bruce CR. Hoy AJ. Turner N. Watt MJ, Allen TL, Carpenter $K$ Cooney GJ, Febbraio MA and

Int J Clin Exp Pathol 2014; $7(8): 5379-5392$ 
Kraegen EW. Overexpression of carnitine palmitoyltransferase-1 in skeletal muscle is suffcient to enhance fatty acid oxidation and im prove high-fat diet-induced insulin resistance. Diabetes 2009; 58: 550-558.

[39] Jambor de Sousa UL, Koss MD. Fillies M, Gah A. Scheeder MR. Cardoso MC. Leonhardt $\mathrm{H}$ Geary N. Langhans W and Leonhardt M. CP Tlalpha over-expression increases long-chain fatty acid oxidation and reduces cell viability with incremental palmitic acid concentration in 293 T cells. Biochem Biophys Res Commun 2005: 338: 757.761.

40] Reddy JK and Rao MS. Lipid metabolism and liver inflammation. It. Fatty liver disease and fatty acid oxidation. Am J Physiol Gastrointest Liver Physiol 2006: 290: G852-G858.

41] Karin $M$ and Gallagher E. TNFR signaling: ubiquitin-conjugated TRAFfic signals control stopand-go for MAPK signaling complexes. Immu nol Rev 2009: 228: 225-240.
[42] Takahashi Y, Soejima $Y$ and Fukusato T. Animat modeis of nonalcoholic fatty liver disease/nonalcoholic steatohepatitis. World J Gastroenter. of 2012: 18: 2300-2308.

[43] Alwahsh SM, Xu M, Schultze FC. Wilting J, Mihm S, Raddatz D. Ramadori G. Combination of alcohol and fructose exacerbates metabolic imbalance in terms of hepatic damage, dyslip. idemia. and insulin resistance in rats. PLoS One 2014: 9: e104220.

[44] Alwahsh SM, Xu M. Seyhan HA. Ahmad S. Mihm S. Ramadori G. Schultze FC. Diet high in fructose leads to an overexpression of lipocalin-2 in rat fatty liver. World $J$ Gastroenterol 2014: $20: 1807-21$ 


\subsection{The anti-TNF- $\alpha$ antibody infliximab inhibits the expression of fat- transporter-protein FAT/CD36 in a selective hepatic-radiation mouse model}

We could previously show that TNF- $\alpha$ is involved in enhancing FAT/CD36 protein level and that this effect could be decreased by anti-TNF- $\alpha$-antibody Infliximab (IFX) in vitro. We now studied the effect of TNF- $\alpha$ and IFX in vivo in a mouse model of singledose liver irradiation. The concentration of triglycerides in liver of irradiated mice was elevated and reached a maximum at $12 \mathrm{~h}$, but the concentration of triglycerides in the serum decreased at the corresponding time points reaching a minimum at $12 \mathrm{~h}$. An increase in fat accumulation could also be shown by Sudan staining with clearly visible fat droplets at 6 and $12 \mathrm{~h}$. Similar to rat liver, radiation-induced increase of FAT/CD36 protein level was observed in the mouse after irradiation and TNF- $\alpha$ administration, respectively. The protein level of the hepatic FAT/CD36 was further enhanced when TNF- $\alpha$ was administered prior to irradiation. In contrast, elevated FAT/CD36 protein level caused by irradiation was prevented when anti-TNF- $\alpha$ (IFX) was administered just before irradiation.

Authors: Gesa Martius, Silke Cameron, Margret Rave-Fränk, Clemens Friedrich Hess, Hendrik A. Wolff and Ihtzaz A. Malik

Status: Accepted for publication in International Journal of Molecular Science on $13^{\text {th }}$ February 2015.

Impact factor: 2.339

\section{Author contribution to the work:}

1. Gesa Martius: performed the main experiments, analyzed the data and wrote the manuscript

2. Silke Cameron: assisted to interpret the data and improved the manuscript

3. Margret Rave-Fränk: optimized the radiation protocol, performed the radiation experiment

4. Clemens Friedrich Hess: assisted to interpret the data and improved the manuscript

5. Hendrik A. Wolff: optimized the radiation protocol, performed the radiation experiment

6. Ihtzaz Ahmed Malik: research theme design, data interpretation, improved the manuscript, financial support 
Article

\title{
The Anti-TNF- $\alpha$ Antibody Infliximab Inhibits the Expression of Fat-Transporter-Protein FAT/CD36 in a Selective Hepatic-Radiation Mouse Model
}

\author{
Gesa Martius ${ }^{1}$, Silke Cameron ${ }^{1}$, Margret Rave-Fränk ${ }^{2}$, Clemens F. Hess ${ }^{2}$, Hendrik A. Wolff ${ }^{2}$ \\ and Ihtzaz A. Malik ${ }^{1, *}$ \\ 1 Department of Gastroenterology and Endocrinology, University Medical Center Goettingen, \\ Robert-Koch-Strasse 40, Goettingen 37075, Niedersachsen, Germany; \\ E-Mails: gesa.martius@med.uni-goettingen.de (G.M.); silke.cameron@med.uni-goettingen.de (S.C.) \\ 2 Department of Radiotherapy and Radiooncology, University Medical Center Goettingen, \\ Robert-Koch-Strasse 40, Goettingen 37075, Niedersachsen, Germany; \\ E-Mails: mfraenk@med.uni-goettingen.de (M.R.-F.); cfhess@med.uni-goettingen.de (C.F.H.); \\ hendrik.wolff@med.uni-goettingen.de (H.A.W.) \\ * Author to whom correspondence should be addressed; E-Mail: i.malik@med.uni-goettingen.de; \\ Tel.: +49-551-398557; Fax: +49-551-396921.
}

Academic Editor: Bing Yan

Received: 3 January 2015/Accepted: 13 February 2015/Published: 2 March 2015

\begin{abstract}
Previously, we reported a radiation-induced inflammation triggering fat-accumulation through fatty-acid-translocase/cluster of differentiation protein 36 (FAT/CD36) in rat liver. Furthermore, inhibition of radiation-induced FAT/CD36-expression by anti-tumor necrosis factor- $\alpha$ (anti-TNF- $\alpha$ ) (infliximab) was shown in vitro. The current study investigates fat-accumulation in a mouse-model of single-dose liver-irradiation (25-Gray) and the effect of anti-TNF- $\alpha$-therapy on FAT/CD36 gene-expression. Mice livers were selectively irradiated in vivo in presence or absence of infliximab. Serum- and hepatic-triglycerides, mRNA, and protein were analyzed by colorimetric assays, RT-PCR, Immunofluorescence and Western-Blot, respectively. Sudan-staining was used demonstrating fat-accumulation in tissue. In mice livers, early $(1-3 \mathrm{~h})$ induction of TNF- $\alpha$-expression, a pro-inflammatory cytokine, was observed. It was followed by elevated hepatic-triglyceride level (6-12 h), compared to sham-irradiated controls. In contrast, serum-triglyceride level was decreased at these time points. Similar to triglyceride level in mice livers, Sudan staining of liver cryosections showed a quick $(6-12 \mathrm{~h})$ increase of fat-droplets after irradiation.
\end{abstract}


Furthermore, expression of fat-transporter-protein FAT/CD36 was increased at protein level caused by radiation or TNF- $\alpha$. TNF- $\alpha$-blockage by anti-TNF- $\alpha$ showed an early inhibition of radiation-induced FAT/CD36 expression in mice livers. Immunohistochemistry showed basolateral and cytoplasmic expression of FAT/CD36 in hepatocytes. Moreover, co-localization of FAT/CD36 was detected with $\alpha$-smooth muscle actin $\left(\alpha-\mathrm{SMA}^{+}\right)$cells and $\mathrm{F} 4 / 80^{+}$macrophages. In summary, hepatic-radiation triggers fat-accumulation in mice livers, involving acute-phase-processes. Accordingly, anti-TNF- $\alpha$-therapy prevented early radiation-induced expression of $\mathrm{FAT} / \mathrm{CD} 36$ in vivo.

Keywords: irradiation; fat accumulation; liver; FAT/CD36; TNF- $\alpha$; infliximab

\section{Introduction}

The liver is the key organ in the body energy homeostasis, due to its ability to metabolize and distribute fatty acids [1]. It is also able to synthesize fatty acids (de novo lipogenesis) as well as to degrade or convert incoming fatty acids from the circulating system [2]. The parenchymal cells of the liver, i.e., hepatocytes, are mainly responsible for the fat metabolism [3].

The accumulation of lipids in the liver can be the result of increased lipolysis from adipose tissue, increased intake of dietary fat, de novo hepatic lipogenesis, and decreased free fatty acid oxidation and hepatic very low density lipoprotein-triglycerides secretion [4]. Pathologically, excessive intrahepatic triglyceride storage is termed steatosis, which may result from a variety of liver treatments and diseases including alcohol, medication and hepatitis C. The established histological criterion for steatosis is the presence of more than $5 \%$ of triglycerides stored in hepatocytes [5].

Fat homeostasis is controlled by a number of factors including different enzymes, transcription factors, membrane and/or intracellular proteins involved in transport, synthesis and degradation of fat [6-9].

The recently discovered fatty-acid-translocase/cluster of differentiation protein 36 (FAT/CD36) plays an active role in hepatic fat metabolism. Free fatty acids are taken up by hepatocytes via transport proteins like the transporter fatty acid translocase (FAT/CD36) $[6,10]$. FAT/CD36 is a membrane-bound glycoprotein present on platelets, mononuclear phagocytes, adipocytes, hepatocytes, and myocytes [6,11-13].

Two isoforms of FAT/CD36 have been described. The active FAT/CD36 protein isoform at $88 \mathrm{kDa}$ has two transmembrane domains [14]. It has a variety of ligands, including fatty acids [15]. Furthermore, an inactive non-glycosylated isoform of FAT/CD36 protein can be detected at $54 \mathrm{kDa}$ [15]. A ligand-specific aspect of FAT/CD36 signaling involves its capacity to deliver biologically active lipids to cells.

There is evidence that fatty acids are oxidized, and bind to FAT/CD36. However, the exact mechanism of fatty acid uptake into liver cells remains unclear $[16,17]$.

Radiation-induced inflammation in healthy and diseased tissue is a now well established fact. Clinically, radiation-induced liver disease (RILD) is a serious clinical complication due mainly to vessel damage [18], and, as a consequence, secretion of inflammatory mediators. Moreover, ionizing radiation is recently reported to alter the expression of proteins involved in the fat metabolism pathway in parallel to accumulation of fat in adipose tissue of rats [19]. This could lead to non-alcoholic liver disease (NALD) 
and radiation-induced fibrosis (RIF) [20]. However, changes in hepatic triglyceride (TG) levels and related proteins after targeted liver radiation have not been fully investigated so far.

Corresponding to accumulation of fat, induction of pro-inflammatory cytokines is also well documented in hepatocellular damage or fibrosis models [21,22]. Among the cytokines, production of TNF- $\alpha$ is one of the earliest events in hepatic inflammation after liver irradiation [23].

As the liver is the pivotal metabolic organ, hepatic impairment may have serious consequences. In our previous work, we have shown that single-dose percutaneous irradiation of rat liver induces periportal inflammation [24] and changes the gene expression of proteins including those of iron metabolism [25] and inflammatory mediators [23,26]. Furthermore, we recently showed that a single-dose liver irradiation can trigger intracellular fat accumulation in the rat liver in parallel to induction of FAT/CD36 expression. This effect may be conveyed by radiation-induced TNF- $\alpha$ expression. We also showed that FAT/CD36 was induced by irradiation or TNF- $\alpha$ in vitro in a human cell line (human monocytic cell line U937). In contrast, anti-TNF- $\alpha$ treatment reduced this up-regulating effect of irradiation in vitro. In the current study, we extended our previous knowledge and showed that irradiation could trigger fat accumulation in the mouse liver, as observed in the rat model. Furthermore, we could show that anti-TNF- $\alpha$ treatment reduced the radiation-caused induction of FAT/CD36 in mouse liver in vivo.

\section{Results}

\subsection{Real Time PCR Analysis of Tumor Necrosis Factor- $\alpha(T N F-\alpha)$ in Irradiated Mice Liver}

The mRNA expression of TNF- $\alpha$, a major pro-inflammatory cytokine, was analyzed in mouse liver tissue at $1,3,6,12,24$ and $48 \mathrm{~h}$ after irradiation using real-time PCR analysis. A quick and maximum upregulation of TNF- $\alpha$ mRNA (4.2 \pm 0.66 -fold) was detected after 1 and $3 \mathrm{~h}$. The gene expression of TNF- $\alpha$ then decreased but remained above the control levels until $12 \mathrm{~h}$ (Figure 1).

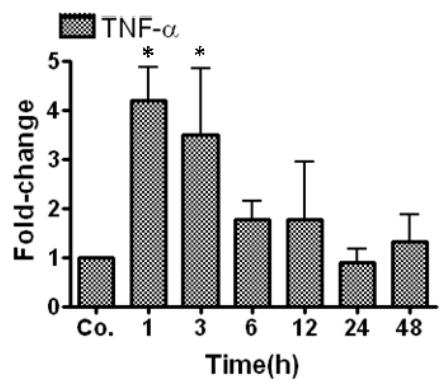

Figure 1. qRT-PCR analysis of total mRNA isolated from mice livers after irradiation. Data are shown as fold-changes in mRNA expression of $T N F-\alpha$ at the various time-points relative to sham-irradiated controls for each time-point. qRT-PCR was normalized by using two housekeeping genes: $\beta$-actin and glyceraldehyde-3-phosphate dehydrogenase $(G A P D H)$. Results represent means \pm standard error mean (S.E.M) of five experiments; ${ }^{*} p<0.05 n=5$. Co. $=$ control. 


\subsection{Changes in Triglycerides (TG) Level in Mice Livers and Serum after Irradiation}

An increase in the TG level was detected after irradiation in mice livers. The elevated TG-content started to be prominent at $3 \mathrm{~h}$ with further increase at $6 \mathrm{~h}$. The increase became significant at $12 \mathrm{~h}$ (12 $\pm 1 \mathrm{mg} / \mathrm{g}$ liver tissue) post-RT compared to sham-irradiated controls $(8.7 \mathrm{mg} / \mathrm{g}$ liver tissue). After reaching that maximum, the TG concentration decreased (Figure $2 \mathrm{~A}$ ). In contrast, the TG concentration in mice serum decreased after irradiation compared to sham-irradiated controls. The TG concentration in the serum significantly decreased at $6 \mathrm{~h}(56.11 \pm 11.5 \mathrm{mg} / \mathrm{dL} v \mathrm{~s}$. control $34 \pm 6 \mathrm{mg} / \mathrm{dL})$ and reached a minimum at $12 \mathrm{~h}(32.2 \pm 4.2 \mathrm{mg} / \mathrm{dL})$ post-RT. After $12 \mathrm{~h}$ post RT the concentration of TG returned to normal values which were reached at $24 \mathrm{~h}$ post RT (Figure 2B). Furthermore, combination of irradiation and infliximab (IFX) showed a minor reduction in total TG levels caused by irradiation alone however it did not reach to significance (data not shown).

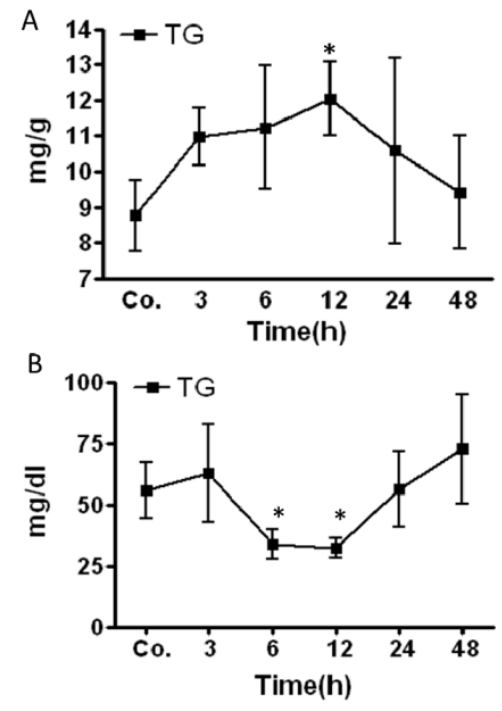

Figure 2. Changes in triglyceride (TG) concentrations in liver tissue lysate (A) and serum (B) of irradiated mice compared to the sham-irradiated controls for each time point. Results represent mean value \pm S.E.M. of five animals $* p<0.05$.

\subsection{Early Accumulation of Fat in Irradiated Mice Liver Tissue}

Sudan III staining showed an increase in fat droplets after RT in comparison to the corresponding sham-irradiated control mice liver cryosections. A very few fat droplets were noticed in Sham irradiated controls (Figure 3C,D) whereas number and size of fat droplets were increased after irradiation. Fat droplets were mainly stained red within hepatocytes. The increased fat droplets accumulation was clearly visible after $6 \mathrm{~h}$ post-RT (Figure 3E,F) with a maximum at $12 \mathrm{~h}$ (Figure 3G,H) compared to a sham-irradiated control (Figure 3C,D). Negative control with counterstaining of only hematoxylin showed no positivity for Sudan III (Figure 3A,B). 


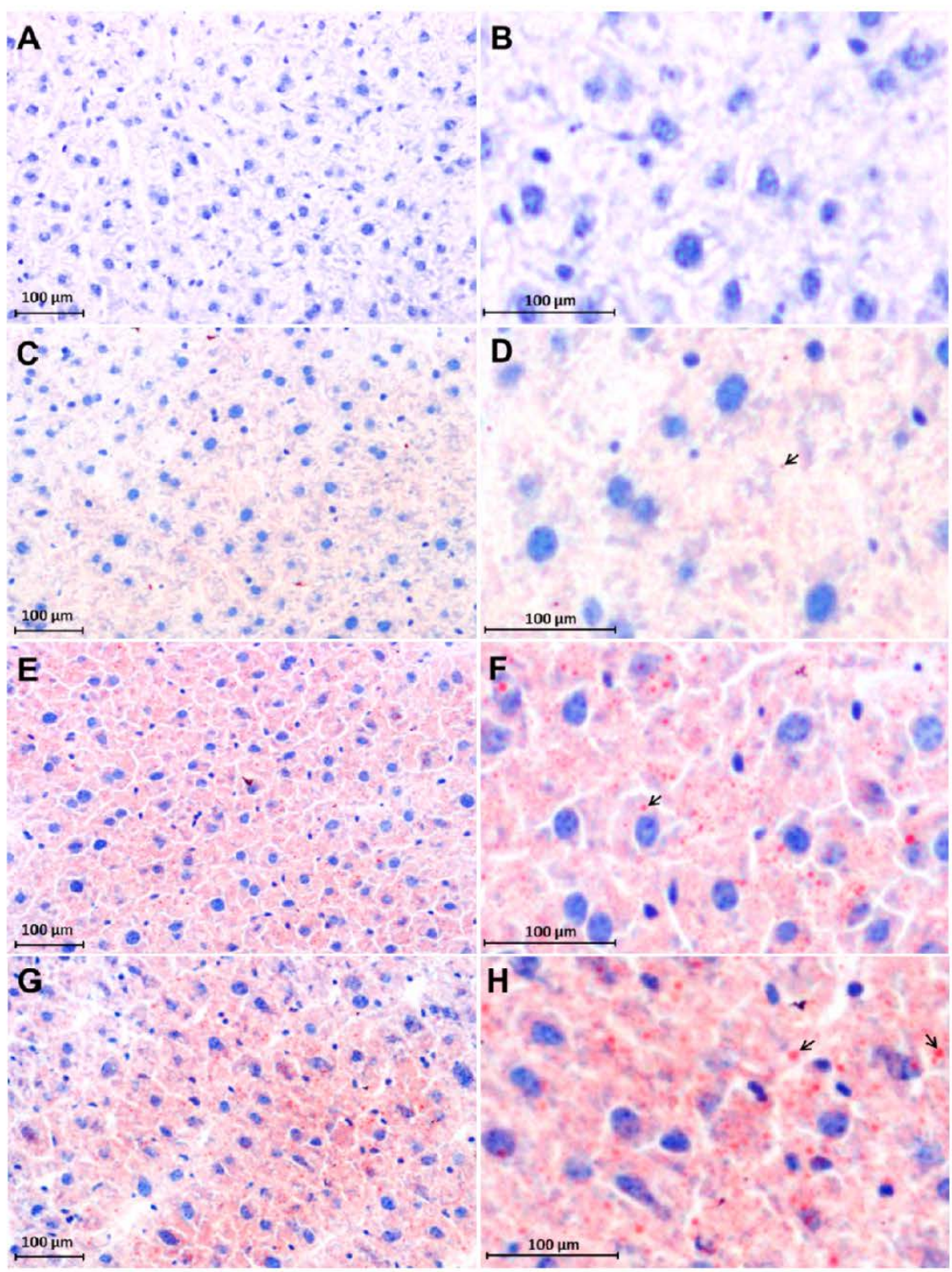

Figure 3. Accumulation of intracellular fat visualized with Sudan III staining in cryosections of livers of sham-irradiated control and irradiated mice. Negative control $(\mathbf{A}, \mathbf{B})$; Sham-irradiated controls $(\mathbf{C}, \mathbf{D}) ; 6 \mathrm{~h}$ post-RT $(\mathbf{E}, \mathbf{F})$ and $12 \mathrm{~h}$ post-RT $(\mathbf{G}, \mathbf{H})$. The intracellular accumulation of fat droplets (red color) increased with the time after irradiation. (B,D,F and $\mathbf{H})$ are magnified areas of (A,C,E and $\mathbf{G})$; The arrows in pictures (D,F and $\mathbf{H})$ show intracellular lipid droplets. Nuclei are stained blue. Results are representative photographs of three animals and six slides per time point (original magnification, $\times 200$ ) . 


\subsection{Changes in FAT/CD36 Protein Level in Mice Livers by Western Blot Analysis}

Western blot was performed to analyze the time-dependent change in protein content of FAT/CD36 in the group of single administration of IFX (G6), irradiated group (G2), irradiated and IFX-administered (G4), single administration of TNF- $\alpha$ (G5) and irradiated and TNF- $\alpha$-administered (G3), respectively (Figure 4). As previously described [27], FAT/CD36 is built as a non-active form (54 kDa) and then post-translationally glycosylated to its active form of $88 \mathrm{kDa}$.

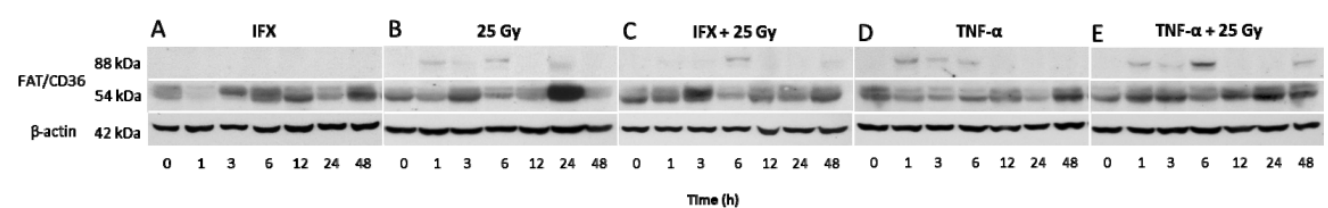

Figure 4. Western blot analysis of fatty-acid-translocase/cluster of differentiation protein 36 (FAT/CD36) from total protein extracts of mice livers. infliximab (IFX)-treated (A, IFX); irradiated (B, 25 Gray $(\mathrm{Gy}))$; IFX-treated and irradiated (C, IFX + 25 Gy); TNF- $\alpha$-treated (D, TNF- $\alpha$ ); and TNF- $\alpha$-treated and irradiated (E, TNF- $\alpha+25$ Gy) mice samples were analyzed by using anti-FAT/CD36 antibody at different time points. Two bands, $\sim 88$ (active isoform) and $\sim 54$ (inactive isoform), were detected. $\beta$-actin was used as loading control. Results are representative for three animals.

A variable increase in protein level of the non-glycosylated isoform of FAT/CD36 (54 kDa) was observed in comparison to untreated controls. The $88 \mathrm{kDa}$ isoform was not detected in the livers of sham-irradiated and IFX-treated mice (Figure 4A). Post-RT, an early increase of the $88 \mathrm{kDa}$ isoform (active isoform) at 1 and $6 \mathrm{~h}$ (Figure 4B) was detected. In contrast, the radiation effect was prevented early at $1-3 \mathrm{~h}$ when anti-TNF- $\alpha$ was administered prior to irradiation. At $6 \mathrm{~h}$, an expression of the $88 \mathrm{kDa}$ isoform was observed (Figure $4 \mathrm{C}$ ). Similar to the observed increase after irradiation, TNF- $\alpha$ administration led to an increase of the active FAT/CD36 protein (Figure 4D) at 1 to $6 \mathrm{~h}$. Furthermore, a synergetic effect of TNF- $\alpha$ and irradiation was observed at 1 to $6 \mathrm{~h}$ with a maximum at $6 \mathrm{~h}$. (Figure $4 \mathrm{E}$ ).

\subsection{Localization of FAT/CD36 in the Liver Using Immunofluorescent Staining}

By means of immunofluorescence staining, using a mouse monoclonal antibody against FAT/CD36, a fluorescent signal for FAT/CD36 was detected in the basolateral membrane and the cytoplasm of hepatocytes (Figure 5). Positivity of FAT/CD36 was furthermore noticed in F4/80- and SMA-positive cells, corresponding to FAT/CD36-co-localization in macrophages (F4/80+) (Figure 5 row A) and vessel walls (SMA+) (Figure 5 row B). A very weak positivity of FAT/CD36 was also detected in bile duct cells $(\mathrm{CK}-19+)$ (Figure 5 row $\mathrm{C})$. Similar to Western blot analysis, an increased expression of FAT/CD36 was detected after $6 \mathrm{~h}$ post-RT compared to sham irradiated controls (Figure 6A,B). The negative control showed no specific signals (not shown). 


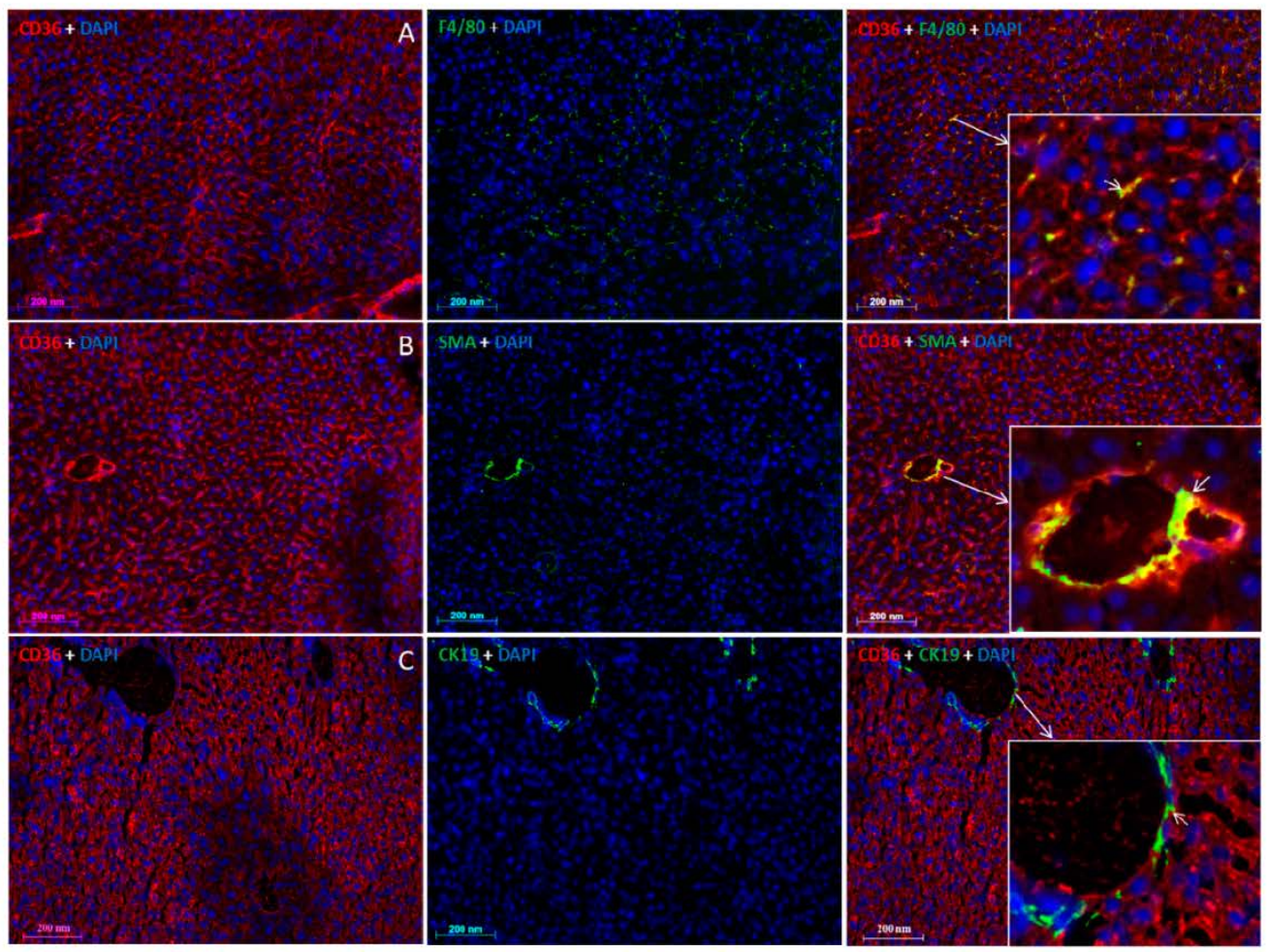

Figure 5. Immunofluorescence double-staining of mice liver cryosections. Row A: Monoclonal antibody against FAT/CD36 (A left, red), monoclonal antibody directed against F4/80 (A middle, green) and merged FAT/CD36 and F4/80 (A right); Row B: Monoclonal antibody against FAT/CD36 (B left, red), monoclonal antibody directed against SMA (B middle, green) and merged FAT/CD36 and SMA (B right); Row C: Monoclonal anti-FAT/CD36 antibody ( $\mathrm{C}$ left, red), polyclonal antibody directed against CK19 (C, middle, green) and merged FAT/CD36 and CK19 (C right). Nuclei staining was done with (DAPI). The insets show higher magnification. Results show the representative picture of three animals and six slides (original magnification, $\times 200$ ). 

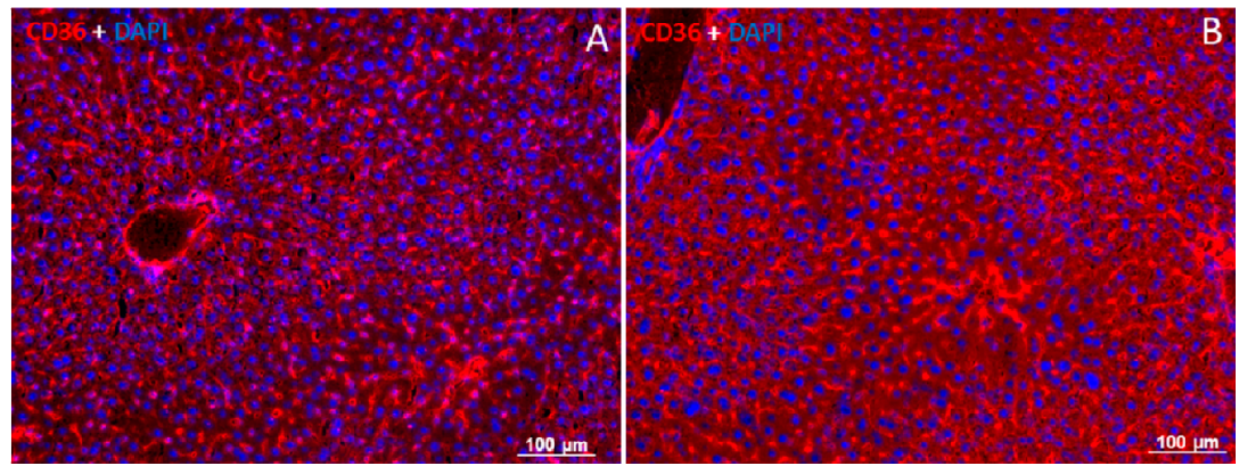

Figure 6. Immunofluorescence detection of FAT/CD36 in liver cryosections of sham-irradiated control and irradiated mice. Sham-irradiated controls (A); $6 \mathrm{~h}$ post-RT (B). Staining with the monoclonal anti-FAT/CD36 antibody showed an increased protein expression of FAT/CD36 (red) after irradiation. Counter staining of the nuclei was done with 4',6-diamidino-2-phenylindole (DAPI). Results show the representative picture of three animals and six slides (original magnification, $\times 100$ ).

\section{Discussion}

Previously, we reported the induction of an inflammatory response in rat liver by single-dose liver irradiation [24]. A major pro-inflammatory cytokine induced by liver irradiation is TNF- $\alpha$ [26]. The increase in TNF- $\alpha$ expression is accompanied by increased fat accumulation [28]. Furthermore, we and others showed that fat accumulation in rat liver is reflected by increased expression of genes involved in fatty acid metabolism as well as increase in fatty acid translocase, a fat transport protein (FAT/CD36) [7,28,29].

Therefore, the aim of this work was to ascertain if selective percutaneous liver irradiation could increase fat transport into mice livers similar to what was observed in rat livers [28]. Furthermore, we investigated whether anti-TNF- $\alpha$ (infliximab, IFX) treatment could reverse the radiation-induced expression of fat transporter protein $\mathrm{FAT} / \mathrm{CD} 36$ in vivo.

In our mouse model, we could show increased hepatic TG levels, whilst TG serum levels were decreased. The accumulation of fat was further confirmed by Sudan staining. Accordingly, increased protein levels of the fat transporter protein FAT/CD36 were observed after mouse liver irradiation as well as after TNF- $\alpha$ treatment in mice. This effect was further enhanced when TNF- $\alpha$ was injected before mice liver irradiation. In contrast, the induction of FAT/CD36 expression by irradiation was prevented at early time points by anti-TNF- $\alpha$ (infliximab) therapy in mice.

These results are similar to our previous study where we showed in a human monocyte cell-line (U937) in vitro that anti-TNF- $\alpha$ (infliximab), antibody against soluble TNF- $\alpha$, inhibits FAT/CD36 protein expression, thus preventing the increase of FAT/CD36 caused by TNF- $\alpha$. In agreement, several previous studies reported that anti-TNF- $\alpha$ therapy is helpful to inhibit the development of steatohepatitis in patients with severe alcoholic steatohepatitis and nonalcoholic fatty liver disease in rodents and humans [30,31]. 
Another important aspect of the present study was to show that FAT/CD36 was not only expressed in the hepatocytes but was also observed in liver macrophages (i.e., Kupffer cells), smooth muscle cells and weak expression in the bile duct cells. The late increase of FAT/CD36 after irradiation combined with anti-TNF- $\alpha$ treatment might result from FAT/CD36 expression by these cells, i.e., liver macrophages, and not by hepatocytes.

The liver regulates the metabolism of glucose, proteins and fat. As the liver is the main organ for metabolism, its functional impairment has serious consequences. An inequality among fatty acid uptake, synthesis, oxidative and secretory pathways of fatty acids leads to hepatic steatosis [4] or steatohepatitis, which in turn may induce liver fibrosis and as a consequence leads to cirrhosis. The complicated process of fatty acid uptake is controlled by several proteins. Among them, the role of FAT/CD36 is crucial.

Previous studies reported that overexpression of FAT/CD36 confers increased fatty acid and lipoprotein influx and/or utilization [32]. Accordingly, it is associated with hepatic steatosis or metabolic disorders [33]. Increased expression of FAT/CD36 has also been reported in experimental models of NAFLD and patients [34]. Interestingly, ablation of FAT/CD36-mediated lipid uptake into liver or muscle prevented lipotoxicity in several animal models [7,35]. These studies confirm the importance of FAT/CD36 in hepatic lipid uptake, similarly in human and animal models.

Clinically, radiation-induced liver disease (RILD) is a serious complication [36] mainly due to radiation-induced damage of microcirculation, redox-stress mechanisms and inflammatory responses. Although a relation between hepatic inflammation and fat accumulation has already been established [1], an interaction between hepatic fat accumulation (through up-regulation of transporter mechanisms) and the radiation-induced inflammatory response (mediated by cytokine secretion) has not been investigated so far. Irradiation-triggered tissue fat accumulation with disturbance of metabolic pathways has only been reported in extrahepatic (i.e., mice gonadal adipose) tissue after irradiation [19]. It has further been suggested, that FAT/CD36 plays a role in long-chain fatty acid uptake not only into the cell, but also into the mitochondria and thus is directly related to the energy metabolism of the cell, its up-regulation inducing an increased capacity for fatty acid oxidation [37]. Mitochondrial fatty acid oxidation is the source of increased production of reactive oxygen species (ROS) [38], which could be true in our current study as increased ROS production after irradiation was observed in this model (Malik et al., manuscript in preparation). Furthermore, a direct effect of radiation on mitochondria, resulting in mitochondrial ROS production has also been proposed [39]. Mitochondrial participation might explain that FAT/CD36 expression was also seen in Kupffer cells and smooth muscle cells, which both are affected by radiation and hypoxia.

In fact, fat accumulation is a multifactorial process. Therefore it could be suggested that more than one factor (FAT/CD36) needs to be inhibited to control fat accumulation in the liver. We concentrated on TNF- $\alpha$, as we know that it is elevated after irradiation and is the main cytokine in our model inducing FAT/CD36 expression, a major fat transporter protein. Further studies will need to be performed to explore the relationship of radiation-induced inflammatory mechanisms and fatty acid uptake with proteins involved in energy metabolism as well as oxidative stress mechanisms following liver irradiation. 


\section{Material and Methods}

\subsection{Materials}

All chemicals used were of analytical grade and purchased from commercial sources as follows: real-time polymerase chain reaction (PCR) primers, moloney murine leukemia virus (M-MLV) reverse transcriptase, reverse transcription buffer, $0.1 \mathrm{M}$ dithiothreitol (DTT), and Platinum SYBR green qPCR UDG mix were from Invitrogen (Carlsbad, CA, USA); dNTPs, Protector RNase inhibitor, Klenow enzyme, primer oligo (dT)15 for complementary DNA (cDNA) synthesis, and Salmon sperm DNA were from Roche (Penzberg, Germany); Hybond N nylon membranes were purchased from Amersham Pharmacia Biotech (Amersham, UK), 4,6-diamidino-2-phenylindole (DAPI) from Southern Biotech (Birmingham, AL, USA). All other reagents and chemicals were from Sigma-Aldrich (St. Louis, MO, USA) or Merck (Darmstadt, Germany).

\subsection{Animal Model}

Male mice of C57BL/6J strain of about 20-28 gram body weight were purchased from Charles River Laboratories (Sulzfeld, Germany). Selective mouse liver irradiation was performed percutanously with a single dose of $25 \mathrm{~Gy}$ (dose rate of $2.4 \mathrm{~Gy} / \mathrm{min}$ ). A lead protection shield was used to protect the mouse body, exposing only the liver to irradiation. Irradiation was done in the presence/absence of TNF- $\alpha$ IFX using a RS 225 X-ray Research System from Gulmay Medical Ltd. (Camberley, UK) operating at $200 \mathrm{kV}$, $15 \mathrm{~mA}$, and with $0.5-\mathrm{mm}$ Copper filtration. Animals were anaesthetized by inhaling Sevoflurane from Abbott GmbH \& Co. KG (Wiesbaden, Germany). Sham-irradiated control animals were handled simultaneously. Treated animals and sham-irradiated controls were sacrificed at 1, 3, 6, 12, 24 and $48 \mathrm{~h}$ after irradiation. All animals received humane care in accordance to the German Law for the Protection of Animals and the institutional guidelines. The treatment of the mice, and the experiments were approved (approval number: 33.9-42502-04-10/0158 on 20 July 2010) by the local committee of University of Goettingen and public authority on animal welfare.

\subsection{Animal Groups of Different Treatments}

Mice were randomly assigned into 6 groups (see Table 1). Group 1 (G1) were sham-irradiated controls, group 2 (G2) contained mice receiving a single-dose treatment of 25 Gy. Group 3 (G3) and group 4 (G4) were given combined treatment of intraperitoneally administered single injection of TNF- $\alpha(2 \mu \mathrm{g} / \mathrm{mouse})$ or IFX (10 mg/kg), respectively, $20 \mathrm{~min}$ before single-dose irradiation of $25 \mathrm{~Gy}$. Group 5 (G5) and group 6 (G6) were given a TNF- $\alpha(2 \mu \mathrm{g} /$ mouse $)$ or IFX dose $(10 \mathrm{mg} / \mathrm{kg})$, respectively, however, they did not receive radiation treatment. In preliminary separate experiments with doses of 5 and $10 \mathrm{mg} / \mathrm{kg}$ for IFX and 1 and $2 \mu \mathrm{g} /$ mouse for the TNF- $\alpha$, the doses were optimized. The best results were obtained with $10 \mathrm{mg} / \mathrm{kg}$ for IFX and $2 \mu \mathrm{g} /$ mouse for TNF- $\alpha$. 
Table 1. Different groups of mice based on their treatment used in the study.

\begin{tabular}{cccccc}
\hline Group 1 (G1) & Group 2 (G2) & Group 3 (G3) & Group 4(G4) & Group 5(G5) & Group 6(G6) \\
\hline Sham-irradiated & $25-G y$ & $25-G y+$ TNF- $\alpha$ & 25-Gy + IFX & TNF- $\alpha$ & IFX \\
\hline
\end{tabular}

\subsection{Staining of Triglycerides in Irradiated Mice Liver Tissue}

Triglycerides were stained in unfixed cryostat liver sections $(5 \mu \mathrm{m})$ from mice by Sudan III from Morphisto (Frankfurt, Germany) to study the histology of irradiated liver tissues at different time points compared to a sham-irradiated control. Sudan III-stained slides were evaluated by using a BX43 light microscope and digital DP21 camera by Olympus (Tokyo, Japan). Counterstaining of the nuclei was performed by Hematoxylin from Morphisto (Frankfurt, Germany).

\subsection{Immunofluorescent Double-Staining}

Immunofluorescence staining was performed as described before [24]. For double-staining monoclonal FAT/CD36 antibody was co-incubated with either polyclonal antibody directed against CK19, polyclonal antibody directed against $\mathrm{F} 4 / 80$ or monoclonal antibody directed against SMA. Cryosections of $5 \mu \mathrm{m}$ thickness were fixed with acetone/methanol, washed in PBS and subsequently incubated with blocking medium ( $90 \%$ of a $0.1 \%$ BSA, $10 \%$ FCS in PBS) for $1 \mathrm{~h}$ at room temperature. The antibody dilutions were applied over night at $4{ }^{\circ} \mathrm{C}$ onto the sections using a FAT/CD36 monoclonal antibody from Abcam (Cambridge, UK) and F4/80 monoclonal antibody from Abcam (Cambridge, UK) CK19 polyclonal antibody from Abcam (Cambridge, UK) and SMA monoclonal antibody from Sigma-Aldrich (St. Louis, MO, USA) respectively. Non-immune serum was used as negative control. (4',6-diamidino-2-phenylindole (DAPI)); SouthernBiotech (Birmingham, AL, USA) served as nucleic acid stain. The slides were observed by using an Axiovert 200M epifluorescence microscope Zeiss (Jena, Germany).

\subsection{Triglyceride Profile in Serum and Liver Tissue of Mice after Irradiation}

Liver tissues and serum samples were collected from mice at the studied time points, tissues were frozen in liquid nitrogen and both were stored at $-80^{\circ} \mathrm{C}$. Frozen liver portions (approximately $100 \mathrm{mg}$ ) were homogenized in 5\% Triton X-100 Merck (Darmstadt, Germany). The concentrations of triglycerides in liver lysate and serum samples were determined by utilizing the automated systems of the central laboratory of the Institute of Clinical Chemistry in University Medical Center Goettingen.

\subsection{RNA Isolation and Real-Time PCR Analysis}

Total RNA from the livers of irradiated and sham-irradiated mice was isolated after homogenization in Trizol ${ }^{\circledR}$ (Invitrogen) according to manufacturers' protocol. For real-time PCR, reverse transcription of the extracted RNA samples was performed using a Superscript kit from Invitrogen as described previously [24]. Briefly, cDNA was generated by reverse transcription of $1 \mu \mathrm{g}$ of total RNA using $100 \mathrm{nM}$ of dNTPs, $50 \mu \mathrm{M}$ of primer oligo dT15, $200 \mathrm{U}$ of moloney murine leukaemia virus reverse transcriptase (M-MLV RT), $16 \mathrm{U}$ of protector RNase inhibitor in RT buffer and $2.5 \mu \mathrm{L}$ of $0.1 \mathrm{M}$ DTT; real time PCR was performed using a StepOnePlus ${ }^{\mathrm{TM}}$ sequence detection system from Applied Biosystems (Darmstadt, 
Germany) with primer detecting TNF- $\alpha$-sequence (fwd 5'-CAAACCACCAAGTGGAGGAG-3', rev 3'-GTGGGTGAGGAGCACGTAGT-5'), GAPDH (fwd 5'-AGAACATCATCCCTGCATCC-3', rev 3'-CACATTGGGGGTAGGAACAC-5') and $\beta$-actin (fwd 5'-ATTGTTACCAACTGGGACGACATG-3' rev 3'-CGAAGTCTAGAGCAACATAGCACA-5) as housekeeping genes. Fold change expression was calculated using threshold cycle $\left(C_{t}\right)$ values. The primers were synthesized by Invitrogen.

\subsection{Protein Extraction from Liver Tissue}

About $50 \mathrm{mg}$ frozen tissue was homogenized with an Ultra-turrax TP 18/10 from Cole-Parmer (Vernon Hills, IL, USA), three times for $10 \mathrm{~s}$ each, in $10 \mathrm{vol} 50 \mathrm{mM}$ TRIS-HCl buffer, pH 7.4, containing $150 \mathrm{mM}$ sodium chloride, $1 \mathrm{mM}$ EDTA, $1 \%$ Triton X-100, $1 \mathrm{mM}$ phenylmethane sulfonyl-fluoride (PMSF), $1 \mathrm{mM}$ benzamidine, $1 \mathrm{mg} / \mathrm{mL}$ leupeptin, $10 \mathrm{mM}$ chymostatin, $1 \mathrm{mg} / \mathrm{mL}$ antipain, and $1 \mathrm{mg} / \mathrm{mL}$ pepstatin $\mathrm{A}$. The entire procedure was carried out at $4{ }^{\circ} \mathrm{C}$. Crude homogenates were passed five times through a $22 \mathrm{G}$ needle attached to a syringe and centrifuged for $5 \mathrm{~min}$ at $10,000 \times \mathrm{g}$ at $4{ }^{\circ} \mathrm{C}$. The protein concentration was determined in supernatants by using the $\mathrm{BCA}$ (bicinchoninic acid) protein assay reagent kit from Pierce (Rockford, IL, USA). Aliquots of the homogenates were stored at $-20^{\circ} \mathrm{C}$ until further used for Western blot analysis.

\subsection{Western Blot Analysis}

Samples of $50 \mu \mathrm{g}$ protein were applied per well and subjected to polyacrylamide gel electrophoresis using NuPAGE 4\%-12\% Bis-Tris Gel from Invitrogen (Carlsbad, CA, USA) under reducing conditions [40]. After electrophoresis, the proteins were transferred to Hybond-ECL (enhanced chemiluminescence) nitrocellulose membranes [41]. Immunodetection was performed according to the ECL Western blotting protocol described before [28]. The antibody used in this study was monoclonal anti-FAT/CD36 from Abcam (Cambridge, UK). $\beta$-actin from Sigma-Aldrich (St. Louis, MO, USA) was used for equal loading.

\subsection{Statistical Analysis}

The data were analyzed using Graph pad Prism 4 software (San Diego, CA, USA). All experimental errors are shown as S.E.M. Statistical significance was calculated by student $t$-test. Significance was accepted at $* p<0.05$.

\section{Conclusions}

In summary, selective liver radiation and acute phase processes triggered fat uptake via FAT/CD36 into mice livers from the serum. Accordingly, anti-TNF- $\alpha$ therapy prevented early radiation-induced expression of FAT/CD36 in vivo. As TNF- $\alpha$ is an important pro-inflammatory cytokine in irradiation-mediated liver damage and induces FAT/CD36 expression, neutralization of TNF- $\alpha$ using an anti-TNF- $\alpha$ antibody seems to be a strategy to prevent further irradiation damage including metabolic changes. 


\section{Acknowledgments}

This work was supported by grants from the German Research Foundation "Deutsche Forschungs Gemeinschaft" (DFG Project MA 5488/2-1). Furthermore, we acknowledge support by the German Research Foundation and the Open Access Publication Funds of the Göttingen University. We would also like to acknowledge the technical assistance of Jutta Blumberg and Ulrike Wegner.

\section{Author Contributions}

Author contributions: Ihtzaz A. Malik designed the research theme, interpreted the data and improved the manuscript; Gesa Martius performed the main experiments, analyzed the data and wrote the manuscript; Hendrik A. Wolff and Margret Rave-Fränk optimized the radiation protocol and helped in performing the radiation experiment; Silke Cameron and Clemens F. Hess assisted to interpret the data and improved the manuscript.

\section{Conflicts of Interest}

The authors declare no conflict of interest.

\section{References}

1. Reddy, J.K.; Rao, M.S. Lipid metabolism and liver inflammation. II. Fatty liver disease and fatty acid oxidation. Am. J. Physiol. Gastrointest. Liver Physiol. 2006, 290, G852-G858.

2. Tamura, S.; Shimomura, I. Contribution of adipose tissue and de novo lipogenesis to nonalcoholic fatty liver disease. J. Clin. Investig. 2005, 115, 1139-1142.

3. Hayhurst, G.P.; Lee, Y.H.; Lambert, G.; Ward, J.M.; Gonzalez, F.J. Hepatocyte nuclear factor $4 \alpha$ (nuclear receptor 2A1) is essential for maintenance of hepatic gene expression and lipid homeostasis. Mol. Cell. Biol. 2001, 21, 1393-1403.

4. Tilg, H.; Moschen, A.R. Evolution of inflammation in nonalcoholic fatty liver disease: The multiple parallel hits hypothesis. Hepatology 2010, 52, 1836-1846.

5. Hubscher, S.G. Histological assessment of non-alcoholic fatty liver disease. Histopathology 2006, 49, 450-465.

6. Berk, P.D. Regulatable fatty acid transport mechanisms are central to the pathophysiology of obesity, fatty liver, and metabolic syndrome. Hepatology 2008, 48, 1362-1376.

7. Koonen, D.P.; Jacobs, R.L.; Febbraio, M.; Young, M.E.; Soltys, C.L.; Ong, H.; Vance, D.E.; Dyck, J.R. Increased hepatic CD36 expression contributes to dyslipidemia associated with diet-induced obesity. Diabetes 2007, 56, 2863-2871.

8. Silverstein, R.L.; Febbraio, M. CD36, a scavenger receptor involved in immunity, metabolism, angiogenesis, and behavior. Sci. Signal. 2009,2 , re3.

9. Winterbourn, C.C. Reconciling the chemistry and biology of reactive oxygen species. Nat. Chem. Biol. 2008, 4, 278-286.

10. Storch, J.; Thumser, A.E. The fatty acid transport function of fatty acid-binding proteins. Biochim. Biophys. Acta 2000, 1486, 28-44. 
11. Bonen, A.; Han, X.X.; Tandon, N.N.; Glatz, J.F.; Lally, J.; Snook, L.A.; Luiken, J.J. FAT/CD36 expression is not ablated in spontaneously hypertensive rats. J. Lipid Res. 2009, 50, 740-748.

12. Luiken, J.J.; Koonen, D.P.; Willems, J.; Zorzano, A.; Becker, C.; Fischer, Y.; Tandon, N.N.; van der Vusse, G.J.; Bonen, A.; Glatz, J.F. Insulin stimulates long-chain fatty acid utilization by rat cardiac myocytes through cellular redistribution of FAT/CD36. Diabetes 2002, 51, 3113-3119.

13. Tanaka, T.; Nakata, T.; Oka, T.; Ogawa, T.; Okamoto, F.; Kusaka, Y.; Sohmiya, K.; Shimamoto, K.; Itakura, K. Defect in human myocardial long-chain fatty acid uptake is caused by FAT/CD36 mutations. J. Lipid Res. 2001, 42, 751-759.

14. Su, X.; Abumrad, N.A. Cellular fatty acid uptake: A pathway under construction. Trends Endocrinol. Metab. 2009, 20, 72-77.

15. Glatz, J.F.; Luiken, J.J.; Bonen, A. Membrane fatty acid transporters as regulators of lipid metabolism: Implications for metabolic disease. Physiol. Rev. 2010, 90, 367-417.

16. Baillie, A.G.; Coburn, C.T.; Abumrad, N.A. Reversible binding of long-chain fatty acids to purified FAT, the adipose CD36 homolog. J. Membr. Biol. 1996, 153, 75-81.

17. Coburn, C.T.; Knapp, F.F., Jr.; Febbraio, M.; Beets, A.L.; Silverstein, R.L.; Abumrad, N.A. Defective uptake and utilization of long chain fatty acids in muscle and adipose tissues of CD36 knockout mice. J. Biol. Chem. 2000, 275, 32523-32529.

18. Lawrence, T.S.; Robertson, J.M.; Anscher, M.S.; Jirtle, R.L.; Ensminger, W.D.; Fajardo, L.F. Hepatic toxicity resulting from cancer treatment. Int. J. Radiat. Oncol. Biol. Phys. 1995, 31, $1237-1248$.

19. Jo, S.K.; Seol, M.A.; Park, H.R.; Jung, U.; Roh, C. Ionising radiation triggers fat accumulation in white adipose tissue. Int. J. Radiat. Biol. 2011, 87, 302-310.

20. Rodningen, O.K.; Borresen-Dale, A.L.; Alsner, J.; Hastie, T.; Overgaard, J. Radiation-induced gene expression in human subcutaneous fibroblasts is predictive of radiation-induced fibrosis. Radiother. Oncol. 2008, 86, 314-320.

21. Jaeschke, H.; Smith, C.W.; Clemens, M.G.; Ganey, P.E.; Roth, R.A. Mechanisms of inflammatory liver injury: Adhesion molecules and cytotoxicity of neutrophils. Toxicol. Appl. Pharmacol. 1996, 139, 213-226.

22. Ramadori, G.; Armbrust, T. Cytokines in the liver. Eur. J. Gastroenterol. Hepatol. 2001, 13, 777-784.

23. Christiansen, H.; Sheikh, N.; Saile, B.; Reuter, F.; Rave-Frank, M.; Hermann, R.M.; Dudas, J.; Hille, A.; Hess, C.F.; Ramadori, G. x-Irradiation in rat liver: Consequent upregulation of hepcidin and downregulation of hemojuvelin and ferroportin-1 gene expression. Radiology 2007, 242, 189-197.

24. Malik, I.A.; Moriconi, F.; Sheikh, N.; Naz, N.; Khan, S.; Dudas, J.; Mansuroglu, T.; Hess, C.F.; Rave-Frank, M.; Christiansen, H.; et al. Single-dose $\gamma$-irradiation induces up-regulation of chemokine gene expression and recruitment of granulocytes into the portal area but not into other regions of rat hepatic tissue. Am. J. Pathol. 2010, 176, 1801-1815.

25. Naz, N.; Ahmad, S.; Cameron, S.; Moriconi, F.; Rave-Frank, M.; Christiansen, H.; Hess, C.F.; Ramadori, G.; Malik, I.A. Differential regulation of ferritin subunits and iron transport proteins: An effect of targeted hepatic X-irradiation. Biomed. Res. Int. 2013, 2013, 353106. 
26. Christiansen, H.; Batusic, D.; Saile, B.; Hermann, R.M.; Dudas, J.; Rave-Frank, M.; Hess, C.F.; Schmidberger, H.; Ramadori, G. Identification of genes responsive to $\gamma$ radiation in rat hepatocytes and rat liver by cDNA array gene expression analysis. Radiat. Res. 2006, 165, 318-325.

27. Lauzier, B.; Merlen, C.; Vaillant, F.; MeDuff, J.; Bouchard, B.; Beguin, P.C.; Dolinsky, V.W.; Foisy, S.; Villeneuve, L.R.; Labarthe, F.; et al. Post-translational modifications, a key process in CD36 function: Lessons from the spontaneously hypertensive rat heart. J. Mol. Cell Cardiol. 2011, 51, 99-108.

28. Martius, G.; Alwahsh, S.M.; Rave-Frank, M.; Hess, C.F.; Christiansen, H.; Ramadori, G.; Malik, I.A. Hepatic fat accumulation and regulation of FAT/CD36: An effect of hepatic irradiation. Int. J. Clin. Exp. Pathol. 2014, 7, 5379-5392.

29. Lavoie, J.M.; Gauthier, M.S. Regulation of fat metabolism in the liver: Link to non-alcoholic hepatic steatosis and impact of physical exercise. Cell. Mol. Life Sci. 2006, 63, 1393-1409.

30. Li, Z.; Yang, S.; Lin, H.; Huang, J.; Watkins, P.A.; Moser, A.B.; de Simone, C.; Song, X.Y.; Diehl, A.M. Probiotics and antibodies to TNF inhibit inflammatory activity and improve nonalcoholic fatty liver disease. Hepatology 2003, 37, 343-350.

31. Manco, M.; Marcellini, M.; Giannone, G.; Nobili, V. Correlation of serum TNF- $\alpha$ levels and histologic liver injury scores in pediatric nonalcoholic fatty liver disease. Am. J. Clin. Pathol. 2007, 127, 954-960.

32. He, J.; Lee, J.H.; Febbraio, M.; Xie, W. The emerging roles of fatty acid translocase/CD36 and the aryl hydrocarbon receptor in fatty liver disease. Exp. Biol. Med. (Maywood) 2011, 236, $1116-1121$.

33. Zhou, J.; Febbraio, M.; Wada, T.; Zhai, Y.; Kuruba, R.; He, J.; Lee, J.H.; Khadem, S.; Ren, S.; Li, S.; et al. Hepatic fatty acid transporter $C d 36$ is a common target of LXR, PXR, and PPAR $\gamma$ in promoting steatosis. Gastroenterology 2008, 134, 556-567.

34. Ge, F.; Zhou, S.; Hu, C.; Lobdell, H.; Berk, P.D. Insulin- and leptin-regulated fatty acid uptake plays a key causal role in hepatic steatosis in mice with intact leptin signaling but not in $o b / o b$ or db/db mice. Am. J. Physiol. Gastrointest. Liver Physiol. 2010, 299, G855-G866.

35. Yang, J.; Sambandam, N.; Han, X.; Gross, R.W.; Courtois, M.; Kovacs, A.; Febbraio, M.; Finck, B.N.; Kelly, D.P CD36 deficiency rescues lipotoxic cardiomyopathy. Circ. Res. 2007, 100, $1208-1217$.

36. Shim, S.J.; Seong, J.; Lee, I.J.; Han, K.H.; Chon, C.Y.; Ahn, S.H. Radiation-induced hepatic toxicity after radiotherapy combined with chemotherapy for hepatocellular carcinoma. Hepatol. Res. 2007, 37, 906-913.

37. Campbell, S.E.; Tandon, N.N.; Woldegiorgis, G.; Luiken, J.J.; Glatz, J.F.; Bonen, A. A novel function for fatty acid translocase (FAT)/CD36: Involvement in long chain fatty acid transfer into the mitochondria. J. Biol. Chem. 2004, 279, 36235-36241.

38. Rosca, M.G.; Vazquez, E.J.; Chen, Q.; Kerner, J.; Kern, T.S.; Hoppel, C.L. Oxidation of fatty acids is the source of increased mitochondrial reactive oxygen species production in kidney cortical tubules in early diabetes. Diabetes 2012, 61, 2074-2083. 
39. Yamamori, T.; Yasui, H.; Yamazumi, M.; Wada, Y.; Nakamura, Y.; Nakamura, H.; Inanami, O. Ionizing radiation induces mitochondrial reactive oxygen species production accompanied by upregulation of mitochondrial electron transport chain function and mitochondrial content under control of the cell cycle checkpoint. Free Radic. Biol. Med. 2012, 53, 260-270.

40. Laemmli, U.K. Cleavage of structural proteins during the assembly of the head of bacteriophage T4. Nature 1970, 227, 680-685.

41. Towbin, H.; Staehelin, T.; Gordon, J. Electrophoretic transfer of proteins from polyacrylamide gels to nitrocellulose sheets: Procedure and some applications. Proc. Natl. Acad. Sci. USA 1979, $76,4350-4354$.

(C) 2015 by the authors; licensee MDPI, Basel, Switzerland. This article is an open access article distributed under the terms and conditions of the Creative Commons Attribution license (http://creativecommons.org/licenses/by/4.0/). 


\section{Discussion}

\subsection{Hepatic fat accumulation and regulation of FAT/CD36: an effect of hepatic irradiation}

The development of advanced ionizing radiation techniques in clinic has opened a new treatment option for tumor therapy. As radiotherapy offers the possibility to focus the tumor precisely, it is more attractive compared to other therapies. The use of radiotherapy in liver is limited as the liver is considered to be radio-sensitive. Furthermore, radiotherapy is often applied together with chemotherapeutic agents, which have to be metabolized by the liver, providing an extra stress to the organ. Accordingly, tumoradjacent tissue is also often affected, which is still another challenge.

The liver is a complex organ consisting of different cell types and tissue compartments responsible for major metabolic processes such as energy metabolism and detoxification. The lobules of the liver represent a sponge of vessels and hepatocyte cords with adjacent Kupffer cells with a varying oxygen tension implicating sensitivity to oxidative stress mechanisms, which is considered to make the liver sensitive to irradiation. The situation can become worse when irradiation is applied together with other chemotherapeutic agents (noxae). It could lead to liver damage (e.g. development of fibrosis/cirrhosis) over the course of time. Hence, irradiation might cause damage of (non-tumoral) liver tissue. Radiation-Induced Liver Disease (RILD) is a clinical problem which is often accompanied with ascites and signs of decreased liver function (Lawrence et al., 1995). Histopathology shows veno-occlusive disease and atrophy of adjacent hepatocytes as a consequence of radiotherapy.

The sensitivity of the liver for irradiation is associated with released inflammatory mediators. Indeed, radiation-induced inflammation factors in healthy and diseased tissue are still only partially understood. Recently, an increased production of acute phase proteins, release of pro-inflammatory mediators, oxidative stress and infiltration of inflammatory cells after liver irradiation is described (Malik et al. 2010;Sultan et al. 2012).

Accordingly, the current study exhibited the hepatic inflammation with infiltration of neutrophil granulocytes around the portal area (Fig. 5) followed by a significant elevation of serum markers for liver damage (Aspartate Transaminase (AST) and Glutamate 
Dehydrogenase (GLDH)). Moreover, an increase of pro-inflammatory cytokines, mainly TNF- $\alpha$, in serum and liver tissue of rat and mouse after irradiation was also observed.
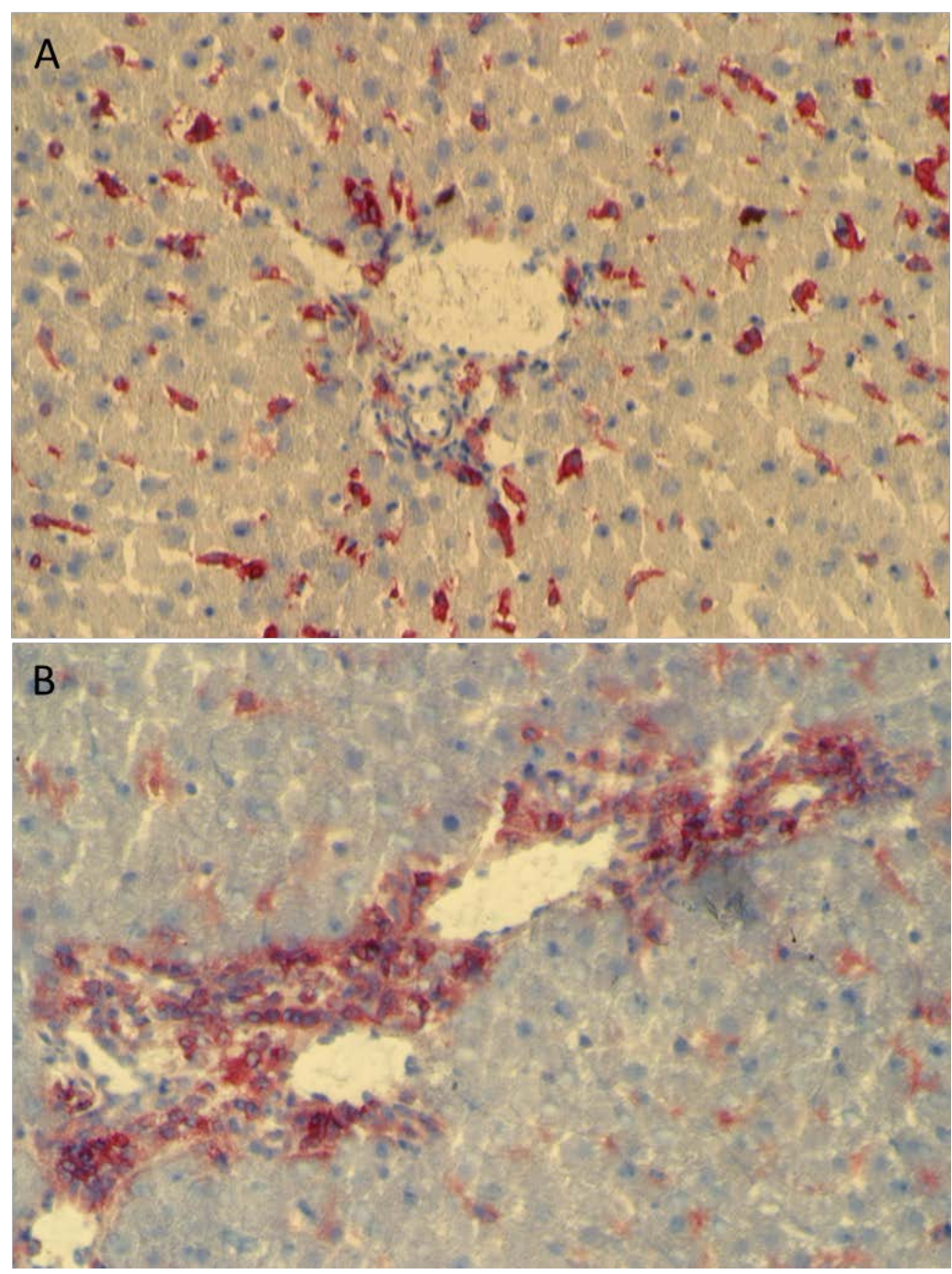

Figure 5: Infiltration of neutrophil granulocytes into hepatic portal area demonstrated by using an antibody against CD11b/c (marker for neutrophil granulocytes and macrophages) after irradiation. A) sham-irradiated (non-irradiated control) B) $6 \mathrm{~h}$ after irradiation (unpublished pictures of our group).

It is universally well-known that the inducers of inflammation are diverse. Chemical substances, microbial invasion or mechanical injury can lead to inflammation processes involving different mediators and cells (Amanzada et al. 2014;Schlayer et al. 1988). Kupffer cells are the main inflammatory mediators-producing cells in the liver such as cytokines and chemokines during inflammatory conditions (Decker 1990). They are 
mostly responsible for eliminating damaging agents and damaged cells (Herskind et al. 1998). The inflamed tissue induces the acute phase response by releasing Acute Phase Proteins (APPs) in order to restrict the area of damage (Ramadori and Christ 1999). These acute phase proteins are released by hepatocytes after cytokine stimulation and are responsible for in turn inducing or decreasing the production of other proteins (Ramadori and Meyer Zum Buschenfelde 1990).

\subsubsection{Hepatic inflammation and fat metabolism}

An association between excessive fat accumulation followed by inflammation has been partially described (Reddy and Rao 2006), but hepatic metabolic changes after irradiation have not been investigated so far. Hence, the aim of the current study was to investigate changes in fat uptake and lipid profile after radiation-induced liver damage. The genes that encode for proteins which are responsible for the transportation of fat into the liver from circulation were studied after selective liver irradiation.

\subsubsection{Fat accumulation and regulation of FAT/CD36 in rat liver after irradiation}

An increase in fat accumulation demonstrated by Nile red staining was noticed after liver irradiation. In parallel, Triglyceride (TG) and Free Fatty Acid (FFA) levels were also elevated in liver tissue, confirming the accumulation of fat within the cells. An early increase (3-6 h) in serum High Density Lipoprotein-Cholesterol (HDL-C), TG and cholesterol levels was also found. According to the increased FFA and TG levels, an increased expression of genes that encode for proteins that are involved in fat metabolism such as enzymes (ACC-2, LPL, Mtf-2), lipoproteins (ApoB100, ApoC3), and transport proteins (L-FABP, FATP-1, FAT/CD36) was detected at 1-48 h in liver tissue at mRNA level after irradiation. FAT/CD36 showed the highest increase among all studied genes.

Hepatic steatosis is a consequence of lipid droplet accumulation in (Tiniakos et al. 2010;Zhou et al. 2008) that may result in metabolic dysfunctions, for instance alteration in $\beta$-oxidation, Very Low-Density Lipoprotein (VLDL) secretion, and pathways participating in fatty acid synthesis (Buettner et al. 2006). The disturbance of long-chain fatty acids (LCFA) and TG metabolism has been reported to be the major cause of nonalcoholic fatty liver disease (NAFLD) as well as of diabetes and insulin resistance. 
Accordingly, more import than export of fatty acids into the cells could be another explanation for intracellular fat accumulation (Fabbrini et al. 2010;Tiniakos et al. 2010).

Several proteins control the processes of fatty acid uptake, synthesis and esterification (“input”) as well as fatty acid oxidation and the export of triglycerides ("output”) and thus regulate the concentration of triglycerides in hepatocytes (Nguyen et al. 2008). ACC-2 regulates the metabolism of fatty acids (Abu-Elheiga et al. 2012). Our study showed an elevated level of ACC-2 mRNA which displays the synthesis of new fatty acids (de novo) and simultaneously an increased fatty acid hydrolysis characterized by an amplified LPL level which is in accordance to previous studies (Degrace et al. 2006).

In order to transport fatty acids into hepatocytes, several proteins are necessary such as putative fatty acid transporter Fatty Acid Translocase (FAT/CD36), Fatty Acid Transport Protein-1 (FATP-1) and Liver Fatty Acid Binding Protein (L-FABP) (Grefhorst et al. 2002;Motojima et al. 1998;Oyama et al. 2005;Storch and Thumser 2000). Expression of L-FABP and FATP-1 was nearly unaffected by irradiation. These proteins are facilitating the transport of fatty acids within the cell and through membranes (Coe and Bernlohr 1998). Nevertheless, the impact of those proteins in liver homoeostasis is not fully understood. However, the putative long chain fatty acid transporter FAT/CD36 showed the highest increase in rat liver after irradiation.

Previous studies reported a role of FAT/CD36 in the process of development of steatosis due to hepatic triglyceride accumulation. (Koonen et al. 2007;Zhou et al. 2008). This observation might be most crucial to explain steatosis in our model. Furthermore, a link between Apo100 and ApoC3 and increased triglyceride concentration has already been documented. These proteins are also known to play a role in fat export (Degrace et al. 2006). An increased expression of these genes could be an additional reason for steatosis through impaired transport of fatty acids out of liver cells.

Irradiation is known to damage the mitochondrial structure of a cell (Gupta et al. 2004). Indeed, disturbance in the hepatic mitochondrial function contributes to hepatic lipid accumulation (Perez-Carreras et al. 2003;Rector et al. 2010). Here, we observed the increased mRNA transcription of carnitine palmitoyltransferase-1 $\alpha$ (CPT-1 $\alpha)$ and Mitofusin-2 (Mtf2); the corresponding proteins are participating in mitochondrial biogenesis. The CPT- $1 \alpha$ protein determines the rate of long-chain fatty acids passing 
through the mitochondrial outer membrane to be metabolized by $\beta$-oxidation (Akkaoui et al. 2009;Bruce et al. 2009;Jambor de Sousa et al. 2005). The enzyme Malonyl-CoA Decarboxylase (MOCAD) is highly expressed in the liver and also takes part in the degradation of fatty acids, as it catalyzes the decarboxylation of malonyl-CoA to acetylCoA (Dyck et al. 2000). CPT1 $\alpha$ and MCOAD are linked by malonyl-CoA; this molecule can inhibit CPT1 $\alpha$ and finally the mitochondrial $\beta$-oxidation (Akkaoui et al. 2009). A highly increased expression of MCOAD and CPT-1 $\alpha$ mRNA in the current study indicates an altered metabolism of fatty acids through mitochondria caused by elevated intracellular fatty acids.

Taken together, our current study established a quick hepatic steatosis model by selective rat liver irradiation. Furthermore, increased transport of fat into the liver could be due to elevated FAT/CD36 level which is influenced by radiation-induced cytokines (e.g TNF$\alpha)$.

Radiation acts through the activation of oxidative stress and induction of inflammatory response. Likewise, radiation-induced microcirculation damage is also known. An association between fat storage (through up-regulation of transporter mechanisms) and the radiation-induced inflammatory response (mediated by cytokine secretion) has not been investigated so far. TNF- $\alpha$ is a key player of inflammation that acts mainly through its transcription factor nuclear transcription factor $(\mathrm{NF})-\mathrm{\kappa B}$ which is a pivotal regulator of several genes involved in i.e. inflammation. Phosphorylation of the p65 subunit and the degradation of I $\kappa \mathrm{B} \alpha$ are known to activate this pathway, which is in accordance to the current study. It suggests that selective liver irradiation induced an acute inflammation mainly through the TNF- $\alpha$-induced NF- $\kappa$ B pathway in our current experimental models.

Another aim was to address the question whether an increase in FAT/CD36 after radiation-induced liver damage could also be due to the direct effect of inflammatory mediators (e.g TNF- $\alpha$ ). Therefore, we inhibited the radiation-induced TNF- $\alpha$ effect by using anti-TNF- $\alpha$ (infliximab, IFX) and examined if blocking TNF- $\alpha$ in the presence of irradiation could prevent the induction of fat transporter protein FAT/CD36 in vitro. To this end, a human monocytic cell line U937 (characteristics of macrophages) was cultured and treated with the "major" pro-inflammatory cytokine TNF- $\alpha$. Similarly to what was observed in liver tissue after irradiation, an increase in protein level of FAT/CD36 was 
found after TNF- $\alpha$ administration and/or irradiation whereas such an increase was inhibited by the addition of anti-TNF- $\alpha$ into culture medium.

\subsection{The anti-TNF- $\alpha$ antibody infliximab inhibits the expression of fat- transporter-protein FAT/CD36 in a selective hepatic-radiation mouse model}

In order to confirm the in vitro data, a similar model of liver irradiation was generated in the mouse. According to data that were gathered in experiments of our rat model, an elevated TG level was detected in the liver of animals in our mouse model in parallel to decreased serum TG level, suggesting increased lipid transport from the circulation into the liver. Accordingly, by means of Sudan III staining, an increased accumulation of fat droplets was observed in the liver, confirming further our results. Corresponding to increased hepatic TG level and excessive number of fat droplets, an elevated level of fat transporter protein FAT/CD36 was noticed at mRNA and protein level in mice liver after irradiation in the presence or absence of TNF- $\alpha$ administration. The magnitude of FAT/CD36 was higher when TNF- $\alpha$ was administered prior to irradiation in comparison to irradiation alone. In contrast to this finding and in agreement with in vitro data, the radiation-induced FAT/CD36 increase was prevented early when anti-TNF- $\alpha$ (infliximab) was administered just before irradiation in mice.

A role of anti-TNF- $\alpha$ therapy in fat-related disorder has already been discussed. Previous reports revealed the beneficial effect of anti-TNF- $\alpha$ therapy in hindering the progression of steatohepatitis, alcoholic steatohepatitis and non-alcoholic fatty liver disease in human. Similar effect was also reported in rodents (Li et al. 2003;Manco et al. 2007).

Another interesting finding in our work was to observe the presence of FAT/CD36 not exclusively in hepatocytes but also in other liver cells such as liver macrophages (Kupffer cells) and smooth muscle actin-positive (SMA) cells. Likewise, a weak detection of FAT/CD36 was also observed in bile duct cells $\left(\mathrm{CK}-19^{+}\right)$. The occurrence of FAT/CD36 in liver non-parenchymal cells might explain the delayed increase of FAT/CD36 in time in mouse liver after irradiation in the presence of anti-TNF- $\alpha$. It indicates the active role of non-parenchymal cells (i.e. liver macrophages), alongside the parenchymal cells (i.e. hepatocytes). 
The main function of the liver is to maintain energy homeostasis in the body as it processes and facilitates the distribution of fatty acids (Reddy and Rao 2006). Functional impairment of the liver as being the main metabolic organ has serious consequences which could lead to hepatic steatosis and ultimately to fibrosis and cirrhosis. Hepatic steatosis is the result of a disturbed balance in fatty acids uptake, synthesis, oxidation and secretion (Tilg and Moschen 2010). Several proteins are known to be involved in the process of fatty acid uptake; among them the role of FAT/CD36 is well accepted (He et al. 2011). For instance, overexpression of FAT/CD36 has been associated with higher fatty acid and lipoprotein influx and/or utilization. Similarly, a role of FAT/CD36 in metabolic disorders and hepatic steatosis is also established (Zhou et al. 2008). Increased level of FAT/CD36 has been reported in experimental models of NAFLD and patients as well (Ge et al. 2010). In several animal models, the lack of FAT/CD36-mediated lipid uptake prevented lipotoxicity in liver and muscle (Koonen et al. 2007; Yang et al. 2007), suggesting the important role of FAT/CD36 in the uptake of fatty acids into the liver.

In fact, irradiation-stimulated tissue fat accumulation has only been reported in extra-hepatic tissue (i.e. mouse gonadal adipose tissue) with a disturbance in metabolic pathway (Jo et al. 2011). Additionally it has been supposed that FAT/CD36 actively participates in long-chain fatty acid uptake into the cell as well as into mitochondria. It suggests a role of FAT/CD36 directly linked to energy metabolism of the cell and higher fatty acid oxidation upon increased production (Campbell et al. 2004).

Indeed, abnormal mitochondrial fatty acid oxidation generates an increased production of Reactive Oxygen Species (ROS) (Rosca et al. 2012) which results in cell injury (inflammation). A similar observation has been made in the same animal model by our group, where an increased amount of ROS was detected after irradiation (Malik et al., manuscript in preparation), suggesting the connection between radiation-induced inflammation and metabolic impairment. Accordingly, a previous study found a direct effect of irradiation on mitochondria which could be the case in our study as well (Yamamori et al. 2012). The involvement of mitochondria could be a possible explanation of the observed late increase of FAT/CD36 protein in the liver after irradiation. This increased production of FAT/CD36 protein could originate from Kupffer cells and smooth muscle actin-positive cells as they are also affected by irradiation and hypoxia. 
Taken together, a rapid hepatic steatosis model was developed by selective liver irradiation in rat and mouse. Moreover, radiation-induced acute phase response was followed by accumulation of hepatic fat via activation of FAT/CD36, a key fat transporter protein. In addition, gene expression of TNF- $\alpha$, a central pro-inflammatory cytokine, was induced after irradiation, the main regulator of FAT/CD36 in the current study. Hence, anti-TNF- $\alpha$ therapy inhibited the FAT/CD36 activation, indicating an important role of this cytokine in hepatic fat metabolism. As fatty acid uptake is a multifactorial process, thus based on our data, it can be concluded that inhibition of more than one gene is required to control fat metabolism regulative pathways. Similarly, inflammatory mediators (e.g.TNF- $\alpha$ ) present an interesting target in this process. Further studies are required to investigate the relationship between radiation-induced inflammation and metabolic changes.

\subsection{Future endeavors and perspectives}

In this study we examined the effect of ionizing radiation on fat metabolism, gene expression and protein level in a rat and mouse model of in vivo single-dose liver irradiation. A time-dependent increase of fat accumulation was observed by lipophilic staining in liver sections at late time points $(12,24,48 \mathrm{~h})$ as well as an increased concentration of lipids such as triglycerides in total liver lysates of irradiated animals. To further study the role of FAT/CD36 in fat accumulation, it could be a fundamental step to concentrate on FAT/CD36-knock-out mice, as it is hypothesized that fat accumulation in liver of those mice would be prevented or at least decreased after irradiation. Additionally, the administration of anti-obesity drugs prior to irradiation might offer the opportunity to investigate the previously mentioned aim. Accordingly, a link between radiation-induced inflammation and fat accumulation was revealed by TNF- $\alpha$ and anti-TNF- $\alpha$ administration in in vitro and in vivo experiments. As TNF- $\alpha$ was inducing FAT/CD36 protein level, it might be of interest to investigate the TNF- $\alpha$ signaling pathway in detail and targeting other inflammatory mediators. As FAT/CD36 is probably not the only protein involved in fatty acid transport, the investigation of interacting partner could be an important aim to understand the mechanisms of radiation-induced fat accumulation in the liver.

From a clinical point of view, regulation of fat metabolism could be an underestimated response in radiotherapy. Further understanding of the fat metabolism before and during radiotherapy could help to understand hepatic lipid metabolism for the prevention and/or treatment of NAFLD. However, prospective studies would need to be performed to correlate 
fat metabolism dynamics following irradiation to the clinical course of patients developing irradiation-related problems. 


\section{References}

Abu-Elheiga L, Wu H, Gu Z, Bressler R, Wakil SJ (2012) Acetyl-CoA carboxylase 2-/mutant mice are protected against fatty liver under high-fat, high-carbohydrate dietary and de novo lipogenic conditions. J Biol Chem 287:12578-12588

Abumrad NA, el-Maghrabi MR, Amri EZ, Lopez E, Grimaldi PA (1993) Cloning of a rat adipocyte membrane protein implicated in binding or transport of long-chain fatty acids that is induced during preadipocyte differentiation. Homology with human CD36. J Biol Chem 268:17665-17668

Adams LA, Angulo P, Lindor KD (2005) Nonalcoholic fatty liver disease. CMAJ 172:899905

Akkaoui M, Cohen I, Esnous C, Lenoir V, Sournac M, Girard J, Prip-Buus C (2009) Modulation of the hepatic malonyl-CoA-carnitine palmitoyltransferase 1A partnership creates a metabolic switch allowing oxidation of de novo fatty acids. Biochem $\mathrm{J}$ 420:429-438

Amanzada A, Moriconi F, Mansuroglu T, Cameron S, Ramadori G, Malik IA (2014) Induction of chemokines and cytokines before neutrophils and macrophage recruitment in different regions of rat liver after TAA administration. Lab Invest 94:235-247

Anscher MS, Crocker IR, Jirtle RL (1990) Transforming growth factor-beta 1 expression in irradiated liver. Radiat Res 122:77-85

Baskar R, Lee KA, Yeo R, Yeoh KW (2012) Cancer and radiation therapy: current advances and future directions. Int J Med Sci 9:193-199

Bonen A, Tandon NN, Glatz JF, Luiken JJ, Heigenhauser GJ (2006) The fatty acid transporter FAT/CD36 is upregulated in subcutaneous and visceral adipose tissues in human obesity and type 2 diabetes. Int J Obes (Lond) 30:877-883

Bruce CR, Hoy AJ, Turner N, Watt MJ, Allen TL, Carpenter K, Cooney GJ, Febbraio MA, Kraegen EW (2009) Overexpression of carnitine palmitoyltransferase-1 in skeletal muscle is sufficient to enhance fatty acid oxidation and improve high-fat diet-induced insulin resistance. Diabetes 58:550-558

Buettner R, Parhofer KG, Woenckhaus M, Wrede CE, Kunz-Schughart LA, Scholmerich J, Bollheimer LC (2006) Defining high-fat-diet rat models: metabolic and molecular effects of different fat types. J Mol Endocrinol 36:485-501

Burdak-Rothkamm S, Prise KM (2009) New molecular targets in radiotherapy: DNA damage signalling and repair in targeted and non-targeted cells. Eur J Pharmacol 625:151-155

Campbell SE, Tandon NN, Woldegiorgis G, Luiken JJ, Glatz JF, Bonen A (2004) A novel function for fatty acid translocase (FAT)/CD36: involvement in long chain fatty acid transfer into the mitochondria. J Biol Chem 279:36235-36241 
Cave M, Deaciuc I, Mendez C, Song Z, Joshi-Barve S, Barve S, McClain C (2007) Nonalcoholic fatty liver disease: predisposing factors and the role of nutrition. J Nutr Biochem 18:184-195

Chalasani N, Wilson L, Kleiner DE, Cummings OW, Brunt EM, Unalp A (2008) Relationship of steatosis grade and zonal location to histological features of steatohepatitis in adult patients with non-alcoholic fatty liver disease. J Hepatol 48:829-834

Cheng JC, Wu JK, Huang CM, Liu HS, Huang DY, Cheng SH, Tsai SY, Jian JJ, Lin YM, Cheng TI, Horng CF, Huang AT (2002) Radiation-induced liver disease after threedimensional conformal radiotherapy for patients with hepatocellular carcinoma: dosimetric analysis and implication. Int J Radiat Oncol Biol Phys 54:156-162

Christiansen H, Batusic D, Saile B, Hermann RM, Dudas J, Rave-Frank M, Hess CF, Schmidberger H, Ramadori G (2006) Identification of genes responsive to gamma radiation in rat hepatocytes and rat liver by cDNA array gene expression analysis. Radiat Res 165:318-325

Christiansen H, Sheikh N, Saile B, Reuter F, Rave-Frank M, Hermann RM, Dudas J, Hille A, Hess CF, Ramadori G (2007) x-Irradiation in rat liver: consequent upregulation of hepcidin and downregulation of hemojuvelin and ferroportin-1 gene expression. Radiology 242:189-197

Coe NR, Bernlohr DA (1998) Physiological properties and functions of intracellular fatty acid-binding proteins. Biochim Biophys Acta 1391:287-306

Decker K (1990) Biologically active products of stimulated liver macrophages (Kupffer cells). Eur J Biochem 192:245-261

Degrace P, Moindrot B, Mohamed I, Gresti J, Du ZY, Chardigny JM, Sebedio JL, Clouet P (2006) Upregulation of liver VLDL receptor and FAT/CD36 expression in LDLR-/apoB100/100 mice fed trans-10,cis-12 conjugated linoleic acid. J Lipid Res 47:26472655

Dixon JB, Bhathal PS, O'Brien PE (2001) Nonalcoholic fatty liver disease: predictors of nonalcoholic steatohepatitis and liver fibrosis in the severely obese. Gastroenterology 121:91-100

Dyck JR, Berthiaume LG, Thomas PD, Kantor PF, Barr AJ, Barr R, Singh D, Hopkins TA, Voilley N, Prentki M, Lopaschuk GD (2000) Characterization of rat liver malonylCoA decarboxylase and the study of its role in regulating fatty acid metabolism. Biochem J 350 Pt 2:599-608

Ekstedt M, Franzen LE, Mathiesen UL, Thorelius L, Holmqvist M, Bodemar G, Kechagias S (2006) Long-term follow-up of patients with NAFLD and elevated liver enzymes. Hepatology 44:865-873

Fabbrini E, Sullivan S, Klein S (2010) Obesity and nonalcoholic fatty liver disease: biochemical, metabolic, and clinical implications. Hepatology 51:679-689 
Fernandez-Real JM, Handberg A, Ortega F, Hojlund K, Vendrell J, Ricart W (2009) Circulating soluble CD36 is a novel marker of liver injury in subjects with altered glucose tolerance. J Nutr Biochem 20:477-484

Frayn KN, Arner P, Yki-Jarvinen H (2006) Fatty acid metabolism in adipose tissue, muscle and liver in health and disease. Essays Biochem 42:89-103

Ge F, Zhou S, Hu C, Lobdell H, Berk PD (2010) Insulin- and leptin-regulated fatty acid uptake plays a key causal role in hepatic steatosis in mice with intact leptin signaling but not in ob/ob or db/db mice. Am J Physiol Gastrointest Liver Physiol 299:G855G866

Gibbons GF, Islam K, Pease RJ (2000) Mobilisation of triacylglycerol stores. Biochim Biophys Acta 1483:37-57

Gibbons GF, Wiggins D, Brown AM, Hebbachi AM (2004) Synthesis and function of hepatic very-low-density lipoprotein. Biochem Soc Trans 32:59-64

Glatz JF, Luiken JJ, Bonen A (2010) Membrane fatty acid transporters as regulators of lipid metabolism: implications for metabolic disease. Physiol Rev 90:367-417

Grefhorst A, Elzinga BM, Voshol PJ, Plosch T, Kok T, Bloks VW, van der Sluijs FH, Havekes LM, Romijn JA, Verkade HJ, Kuipers F (2002) Stimulation of lipogenesis by pharmacological activation of the liver $\mathrm{X}$ receptor leads to production of large, triglyceride-rich very low density lipoprotein particles. J Biol Chem 277:34182-34190

Gupta D, Arora R, Garg AP, Bala M, Goel HC (2004) Modification of radiation damage to mitochondrial system in vivo by Podophyllum hexandrum: mechanistic aspects. Mol Cell Biochem 266:65-77

Guturu P, Duchini A (2012) Etiopathogenesis of nonalcoholic steatohepatitis: role of obesity, insulin resistance and mechanisms of hepatotoxicity. Int J Hepatol 2012:212865

He J, Lee JH, Febbraio M, Xie W (2011) The emerging roles of fatty acid translocase/CD36 and the aryl hydrocarbon receptor in fatty liver disease. Exp Biol Med (Maywood ) 236:1116-1121

Herskind C, Bamberg M, Rodemann HP (1998) The role of cytokines in the development of normal-tissue reactions after radiotherapy. Strahlenther Onkol 174 Suppl 3:12-15

Hoosdally SJ, Andress EJ, Wooding C, Martin CA, Linton KJ (2009) The Human Scavenger Receptor CD36: glycosylation status and its role in trafficking and function. J Biol Chem 284:16277-16288

Jambor de Sousa UL, Koss MD, Fillies M, Gahl A, Scheeder MR, Cardoso MC, Leonhardt H, Geary N, Langhans W, Leonhardt M (2005) CPT1alpha over-expression increases long-chain fatty acid oxidation and reduces cell viability with incremental palmitic acid concentration in 293T cells. Biochem Biophys Res Commun 338:757-761

Jo SK, Seol MA, Park HR, Jung U, Roh C (2011) Ionising radiation triggers fat accumulation in white adipose tissue. Int $\mathrm{J}$ Radiat Biol 87:302-310 
Jong MC, Rensen PC, Dahlmans VE, van der Boom H, van Berkel TJ, Havekes LM (2001) Apolipoprotein C-III deficiency accelerates triglyceride hydrolysis by lipoprotein lipase in wild-type and apoE knockout mice. J Lipid Res 42:1578-1585

Koonen DP, Jacobs RL, Febbraio M, Young ME, Soltys CL, Ong H, Vance DE, Dyck JR (2007) Increased hepatic CD36 expression contributes to dyslipidemia associated with diet-induced obesity. Diabetes 56:2863-2871

Koshariya M, Jagad RB, Kawamoto J, Papastratis P, Kefalourous H, Porfiris T, Tzouma C, Lygidakis NJ (2007) An update and our experience with metastatic liver disease. Hepatogastroenterology 54:2232-2239

Kwon YK, Ha IJ, Bae HW, Jang WG, Yun HJ, Kim SR, Lee EK, Kang CM, Hwang GS (2014) Dose-dependent metabolic alterations in human cells exposed to gamma irradiation. PLoS One 9:e113573

Larter CZ, Chitturi S, Heydet D, Farrell GC (2010) A fresh look at NASH pathogenesis. Part 1: the metabolic movers. J Gastroenterol Hepatol 25:672-690

Lawrence TS, Robertson JM, Anscher MS, Jirtle RL, Ensminger WD, Fajardo LF (1995) Hepatic toxicity resulting from cancer treatment. Int J Radiat Oncol Biol Phys 31:1237-1248

Li Z, Yang S, Lin H, Huang J, Watkins PA, Moser AB, DeSimone C, Song XY, Diehl AM (2003) Probiotics and antibodies to TNF inhibit inflammatory activity and improve nonalcoholic fatty liver disease. Hepatology 37:343-350

Malik IA, Moriconi F, Sheikh N, Naz N, Khan S, Dudas J, Mansuroglu T, Hess CF, RaveFrank M, Christiansen H, Ramadori G (2010) Single-dose gamma-irradiation induces up-regulation of chemokine gene expression and recruitment of granulocytes into the portal area but not into other regions of rat hepatic tissue. Am J Pathol 176:1801-1815

Manco M, Marcellini M, Giannone G, Nobili V (2007) Correlation of serum TNF-alpha levels and histologic liver injury scores in pediatric nonalcoholic fatty liver disease. Am J Clin Pathol 127:954-960

Marchesini G, Brizi M, Bianchi G, Tomassetti S, Bugianesi E, Lenzi M, McCullough AJ, Natale S, Forlani G, Melchionda N (2001) Nonalcoholic fatty liver disease: a feature of the metabolic syndrome. Diabetes 50:1844-1850

Meng S, Cao J, Feng Q, Peng J, Hu Y (2013) Roles of chlorogenic Acid on regulating glucose and lipids metabolism: a review. Evid Based Complement Alternat Med 2013:801457

Motojima K, Passilly P, Peters JM, Gonzalez FJ, Latruffe N (1998) Expression of putative fatty acid transporter genes are regulated by peroxisome proliferator-activated receptor alpha and gamma activators in a tissue- and inducer-specific manner. J Biol Chem 273:16710-16714

Nguyen P, Leray V, Diez M, Serisier S, Le BJ, Siliart B, Dumon H (2008) Liver lipid metabolism. J Anim Physiol Anim Nutr (Berl) 92:272-283

Ong JP, Younossi ZM (2007) Epidemiology and natural history of NAFLD and NASH. Clin Liver Dis 11:1-16, vii 
Oyama Y, Takeda T, Hama H, Tanuma A, Iino N, Sato K, Kaseda R, Ma M, Yamamoto T, Fujii H, Kazama JJ, Odani S, Terada Y, Mizuta K, Gejyo F, Saito A (2005) Evidence for megalin-mediated proximal tubular uptake of L-FABP, a carrier of potentially nephrotoxic molecules. Lab Invest 85:522-531

Perez-Carreras M, Del HP, Martin MA, Rubio JC, Martin A, Castellano G, Colina F, Arenas J, Solis-Herruzo JA (2003) Defective hepatic mitochondrial respiratory chain in patients with nonalcoholic steatohepatitis. Hepatology 38:999-1007

Ramadori G, Christ B (1999) Cytokines and the hepatic acute-phase response. Semin Liver Dis 19:141-155

Ramadori G, Meyer Zum Buschenfelde KH (1990) [The acute phase reaction and its mediators. II: Alpha tumor necrosis factor and interleukin 6]. Z Gastroenterol 28:1421

Rector RS, Thyfault JP, Uptergrove GM, Morris EM, Naples SP, Borengasser SJ, Mikus CR, Laye MJ, Laughlin MH, Booth FW, Ibdah JA (2010) Mitochondrial dysfunction precedes insulin resistance and hepatic steatosis and contributes to the natural history of non-alcoholic fatty liver disease in an obese rodent model. J Hepatol 52:727-736

Reddy JK, Rao MS (2006) Lipid metabolism and liver inflammation. II. Fatty liver disease and fatty acid oxidation. Am J Physiol Gastrointest Liver Physiol 290:G852-G858

Rosca MG, Vazquez EJ, Chen Q, Kerner J, Kern TS, Hoppel CL (2012) Oxidation of fatty acids is the source of increased mitochondrial reactive oxygen species production in kidney cortical tubules in early diabetes. Diabetes 61:2074-2083

Ruhl R, Ludemann L, Czarnecka A, Streitparth F, Seidensticker M, Mohnike K, Pech M, Wust P, Ricke J (2010) Radiobiological restrictions and tolerance doses of repeated single-fraction hdr-irradiation of intersecting small liver volumes for recurrent hepatic metastases. Radiat Oncol 5:44

Schlayer HJ, Laaff H, Peters T, Woort-Menker M, Estler HC, Karck U, Schaefer HE, Decker $\mathrm{K}$ (1988) Involvement of tumor necrosis factor in endotoxin-triggered neutrophil adherence to sinusoidal endothelial cells of mouse liver and its modulation in acute phase. J Hepatol 7:239-249

Schreurs M, Kuipers F, van der Leij FR (2010) Regulatory enzymes of mitochondrial betaoxidation as targets for treatment of the metabolic syndrome. Obes Rev 11:380-388

Sebastian D, Hernandez-Alvarez MI, Segales J, Sorianello E, Munoz JP, Sala D, Waget A, Liesa M, Paz JC, Gopalacharyulu P, Oresic M, Pich S, Burcelin R, Palacin M, Zorzano A (2012) Mitofusin 2 (Mfn2) links mitochondrial and endoplasmic reticulum function with insulin signaling and is essential for normal glucose homeostasis. Proc Natl Acad Sci U S A 109:5523-5528

Shim SJ, Seong J, Lee IJ, Han KH, Chon CY, Ahn SH (2007) Radiation-induced hepatic toxicity after radiotherapy combined with chemotherapy for hepatocellular carcinoma. Hepatol Res 37:906-913 
Storch J, Thumser AE (2000) The fatty acid transport function of fatty acid-binding proteins. Biochim Biophys Acta 1486:28-44

Su X, Abumrad NA (2009) Cellular fatty acid uptake: a pathway under construction. Trends Endocrinol Metab 20:72-77

Sultan S, Cameron S, Ahmad S, Malik IA, Schultze FC, Hielscher R, Rave-Frank M, Hess CF, Ramadori G, Christiansen H (2013) Serum Lipocalin2 is a potential biomarker of liver irradiation damage. Liver Int 33:459-468

Sultan S, Pascucci M, Ahmad S, Malik IA, Bianchi A, Ramadori P, Ahmad G, Ramadori G (2012) LIPOCALIN-2 is a major acute-phase protein in a rat and mouse model of sterile abscess. Shock 37:191-196

Tilg H, Moschen AR (2010) Evolution of inflammation in nonalcoholic fatty liver disease: the multiple parallel hits hypothesis. Hepatology 52:1836-1846

Tiniakos DG, Vos MB, Brunt EM (2010) Nonalcoholic fatty liver disease: pathology and pathogenesis. Annu Rev Pathol 5:145-171

Yamamori T, Yasui H, Yamazumi M, Wada Y, Nakamura Y, Nakamura H, Inanami O (2012) Ionizing radiation induces mitochondrial reactive oxygen species production accompanied by upregulation of mitochondrial electron transport chain function and mitochondrial content under control of the cell cycle checkpoint. Free Radic Biol Med $53: 260-270$

Yang J, Sambandam N, Han X, Gross RW, Courtois M, Kovacs A, Febbraio M, Finck BN, Kelly DP (2007) CD36 deficiency rescues lipotoxic cardiomyopathy. Circ Res 100:1208-1217

Zhang X, Fitzsimmons RL, Cleland LG, Ey PL, Zannettino AC, Farmer EA, Sincock P, Mayrhofer G (2003) CD36/fatty acid translocase in rats: distribution, isolation from hepatocytes, and comparison with the scavenger receptor SR-B1. Lab Invest 83:317332

Zhou J, Febbraio M, Wada T, Zhai Y, Kuruba R, He J, Lee JH, Khadem S, Ren S, Li S, Silverstein RL, Xie W (2008) Hepatic fatty acid transporter Cd36 is a common target of LXR, PXR, and PPARgamma in promoting steatosis. Gastroenterology 134:556567 


\section{Abbreviations}

APP

APR

AST

ATP

CK19

CoA

CT

DNA

DNL

FABP

FAT/CD36

FATP

FFA

GLDH

Gy

$\mathrm{H}$

HCC

HDL-C

IFX

$\mathrm{I} \kappa \mathrm{B} \alpha$

IP

$\mathrm{kDa}$

$\mu \mathrm{m}$

mRNA

$\mathrm{n}$

NAFLD

$\mathrm{NASH}$

NEFA

$\mathrm{NF}-\kappa \mathrm{B}$

$\mathrm{N}$-linked glycosylation

OD

$\mathrm{P}$
Acute phase proteins

Acute phase response

Aspartate aminotransferase

Adenosine triphosphate

Cytokeratin 19

Coenzyme A

Computer-Tomograph

Deoxyribonucleic acid

De novo lipogenesis

Fatty acid binding protein

Fatty acid translocase/cluster of differentiation 36

Fatty acid transport protein

Free fatty acid

Glutamate Dehydrogenase

Gray

Hour

Hepatocellular carcinoma

High density lipoprotein- cholesterol

Infliximab (anti-TNF- $\alpha$ )

$\mathrm{NF} \kappa \mathrm{B}$ inhibitory subunit $\alpha$

Intraperitoneal

Kilodalton

Mikrometer

messenger ribonucleic acid

number of animals per timepoint

Non-alcoholic fatty liver disease

Non-alcoholic steatohepatitis

Non-esterified fatty acid

Nuclear factor $\kappa B$

Nitrogen-linked glycosylation

Optical density

Probability value 
PCR

(q)RT-PCR

RILD

ROS

RT

SEM

SMA

TG

TNF- $\alpha$

VLDL
Polymerase chain reaction

(quantitative) Real-Time-Polymerase Chain Reaction

Radiation-induced liver disease

Reactive oxygen species

Radiation therapy

Standard error of the mean

Smooth muscle actin

Triglyceride

Tumor necrosis factor $\alpha$

Very low-density lipoprotein 


\section{Acknowledgements}

An dieser Stelle möchte ich meinen ganz besonderen Dank an Prof. Dr. med. Dr. h.c. Wolfgang Engel ausdrücken, der mir als Betreuer durch ständige Hilfsbereitschaft und Motivation stets zur Verfügung stand. Auch Herrn Prof. Dr. rer. nat. Wilfried Kramer gilt mein Dank für die konstruktive Kritik an meiner Doktorarbeit.

Ich würde mich auch gerne bei Prof. Dr. med. Giuliano Ramadori für die Idee und die Initiierung des Projekts dieser Dissertation und die Möglichkeit diese Arbeit zu beginnen bedanken.

Ebenso würde ich gerne Prof. Dr. med. Tilman Sauerbruch und Prof. Dr. Volker Ellenrieder für ihre Unterstützung des Projekts in der letzten Phase meiner Doktorarbeit danken.

Mein besonderer Dank gilt Dr. rer. nat. Ihtzaz A. Malik und Dr. med. Silke Cameron für ihre Hilfe bei der Restrukturierung der Thematik meiner Dissertation. Frau Rave-Fränk möchte ich für die technische Hilfe im Projekt Danke sagen.

Hierbei möchte ich nicht die tatkräftige Hilfe des technischen Personals der Abteilung Gastroenterologie und Strahlentherapie vergessen: Frau Ulrike Wegener, Frau Jutta Blumberg, Frau Daniela Gerke, Frau Elke Neumann, Frau Alexandra Bitter und Frau KastenKrapp.

Last but not least: Ohne die Unterstützung meiner Familie wäre diese Arbeit nicht möglich gewesen. Hierbei möchte ich meiner Tochter danken, die mir trotz ihrer Versuche mich von der Arbeit abzubringen, mich diese hat fertigstellen lassen und meinem Mann, der mich immer wieder zur Arbeit zurückgebracht hat. Vielen Dank an meine Mutter, die in jeder Phase für mich da war und motiviert hat. 


\section{Curriculum vitae}

\begin{tabular}{ll} 
Name & Martius \\
First name & Gesa \\
Date of birth & 25.08 .1980 \\
Place of birth & Lüneburg, Germany \\
Nationality & German \\
\hline Family status & Married, 1 child
\end{tabular}

\section{Education}

$2008-2015$

$\mathrm{PhD}$ in Biology

Department of Gastroenterology and Endocrinology

University Medical Center Göttingen

Title: "Effect of radiation on hepatic fat metabolism in rat and mouse: a role of radiation-induced TNF- $\alpha$ in the regulation of FAT/CD36”

Supervisors: Prof. Dr. Dr. W. Engel, PD Dr. W. Kramer

2007

Diploma in Biology

Department of Radiotherapy and Radiooncology

Supervisor: Prof. Dr. O. Einsle

Georg-August-University Göttingen

$2005-2007 \quad$ Main studies

Subjects: Biochemistry, Microbiology, Organic Chemistry

Georg-August-University Göttingen

$2002-2005 \quad$ Basic studies

Justus-Liebig-University Gießen

Abitur at Gymnasium Johanneum Lüneburg 


\section{List of publications}

\section{Publications}

Malik IA,Stange I, Martius G, Cameron S, Rave-Fränk M, Hess CF, Ellenrieder V, Wolff H (2015). Role of PECAM-1 in radiation-induced liver inflammation. JCMM (accepted).

Martius G, Cameron S, Rave-Fränk M, Hess CF, Wolff H, Malik IA (2014). Anti-TNF- $\alpha$ antibody infliximab inhibited the fat-transporter-protein FAT/CD36 expression in selective hepatic radiation mouse model. Int J Mol Sci. 2015 Mar 2;16(3):4682-97.

Martius G, Alwahsh SM, Rave-Fränk M, Hess CF, Christiansen H, Ramadori G, Malik IA (2014). Hepatic fat accumulation and regulation of FAT/CD36: an effect of hepatic irradiation. Int J Clin Exp Pathol. 2014 Jul 15;7(8):5379-92. eCollection 2014.

Wójcik M, Ramadori P, Blaschke M, Sultan S, Khan S, Malik IA, Naz N, Martius G, Ramadori G, Schultze FC (2012). Immunodetection of cyclooxygenase-2 (COX-2) is restricted to tissue macrophages in normal rat liver and to recruited mononuclear phagocytes in liver injury and cholangiocarcinoma. Histochem Cell Biol. 2012 Feb;137(2):217-33.

\section{Conferences and Poster presentations}

Martius G, Alwahsh SM, Rave-Fränk M, Hess CF, Christiansen H, Ramadori G, Malik IA. Hepatic fat accumulation and regulation of FAT/CD36: an effect of hepatic irradiation. Poster abstract accepted for GBS-Jahrestagung 2014, Tübingen.

Martius G, Alwahsh SM, Rave-Fränk M, Hess CF, Christiansen H, Ramadori G, Malik IA. Effect of direct single-dose irradiation on fat metabolism in rat liver: FAT/CD36 as the main responsible protein? Poster presentation at Falk Workshop and GASL conference “Pathophysiology and Treatment of Cholangiocarcinoma”, Tübingen, 2014.

Martius G, Alwahsh SM, Rave-Fränk M, Hess CF, Christiansen H, Ramadori G, Malik IA. The effect of gamma radiation on the expression of genes involved in fat metabolism in rat liver. Poster presentation at Falk Workshop "Translational Research in Chronic Liver Disease”, Heidelberg. 2009. 